\title{
SB 191
}

.W5 T4 


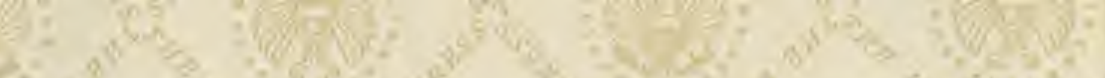

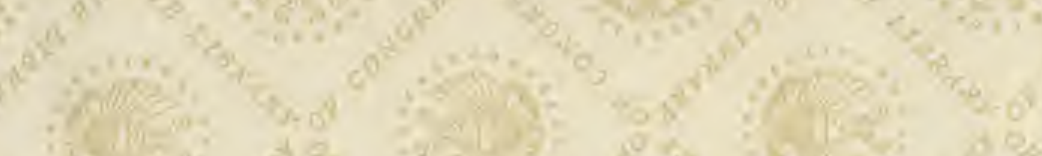
ris W.

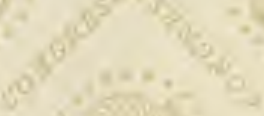

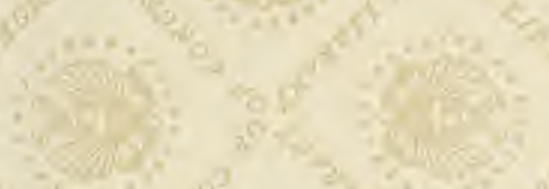

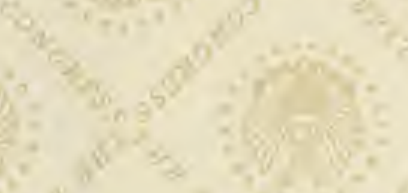

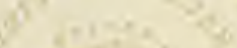
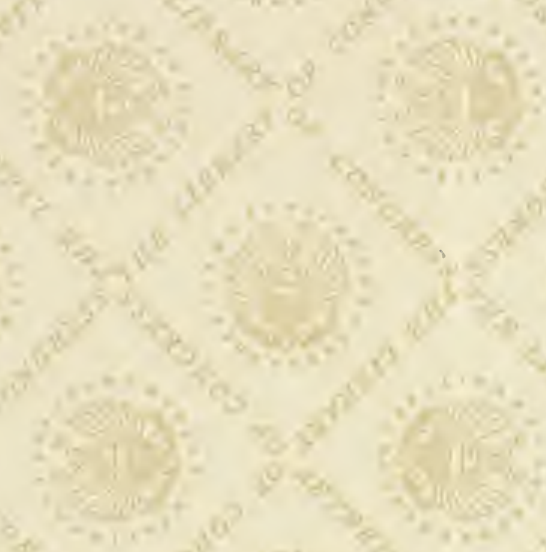

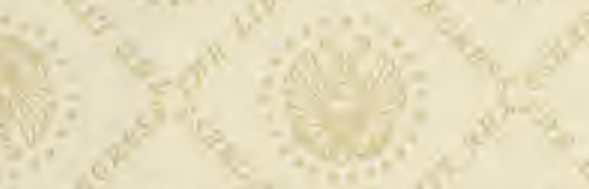

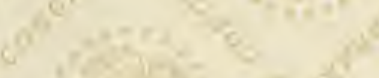

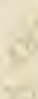

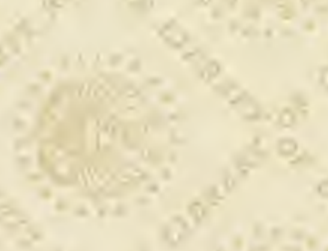

(2)<smiles>C=C1CCC1</smiles>

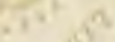

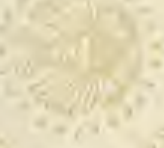

Q

s.

in $y$<smiles>CC1=CCC#C1</smiles>

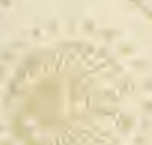

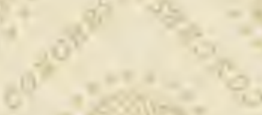

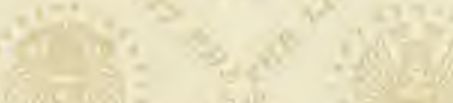

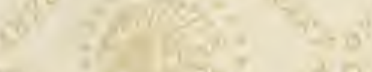

-19
$4 \times 9$

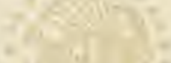

$x^{3}=$

$0^{2}+25$

$18+84$ 16 





\section{Scientific Soil Culture Series}

RICHARD A. HASTE, Editor

Manual of Soil Culture-Campbell

Wheat-TenEyck

\section{IN PREPARATION}

The Soil-Willard

Plant Growth-Haste

Soil Tillage-Campbell

Soil Biology-Bolley

Orchard and Small Fruits-Stephens

Plant Breeding-Buffum

Irrigation and Drainage-Haste

Manual of Soil Culture, two volumes-Campbell

Farm Management-Haste

\section{Campbell Soil Culture Publishing Co.}

Lincoln, Nebraska 


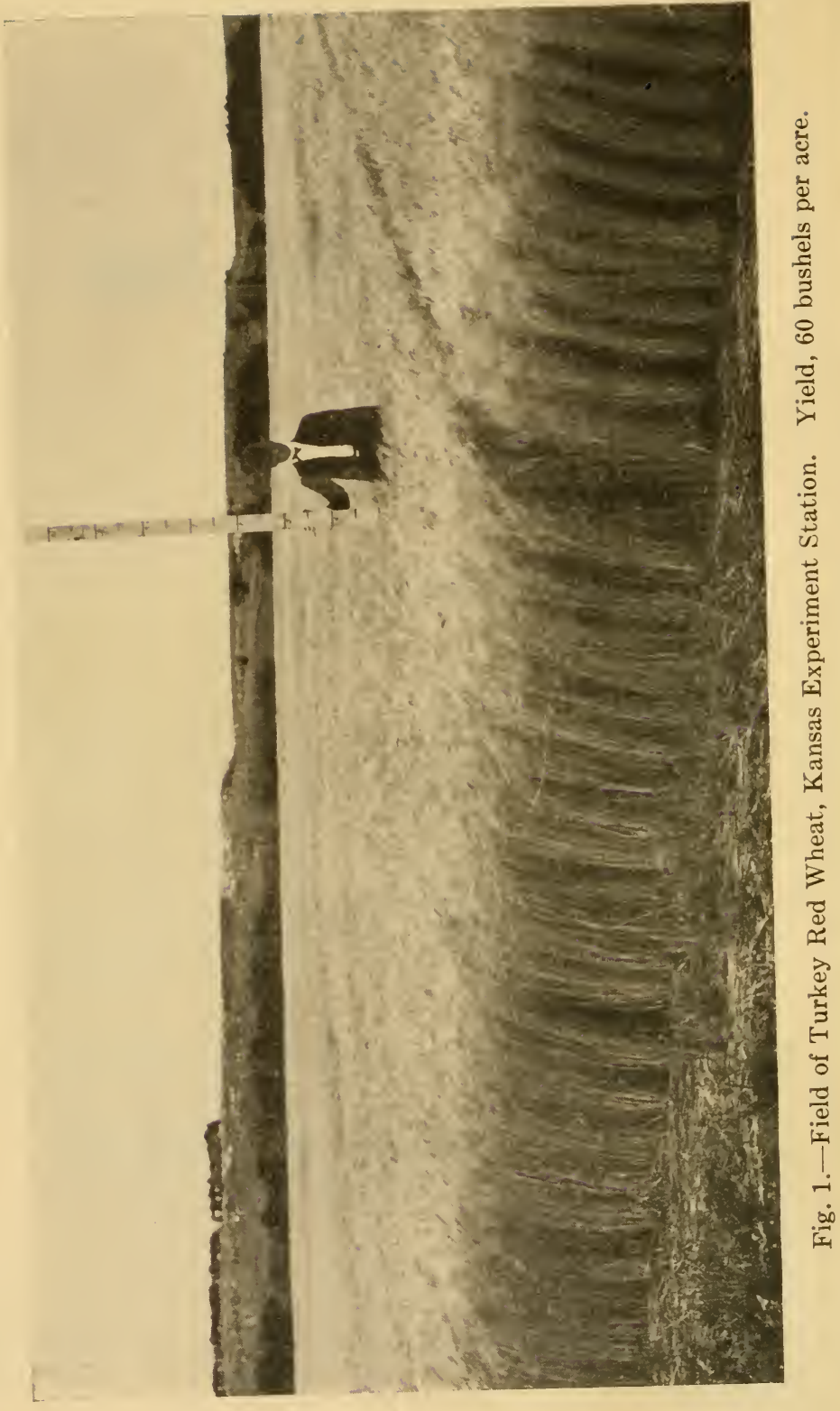




\section{W H E A T}

A Practical Discussion of the Raising, Marketing, Handling and Use of the Wheat Crop, Relating Largely

to the Great Plains Region of the United States and Canada

BY

A. M. TEN EYCK

Professor of Soils, Agricultural Extension Department, Iowa State College. Formerly Professor of Agronomy and Professor of Farm Management, Kansas State Agricultural

College and Superintendent $r \mathrm{t}$. Hays Branch Experiment Station.

\section{FIRST EDITION}




$$
\begin{aligned}
& \text { SB IP } \\
& \text { WD TA }
\end{aligned}
$$

Copyrighted by Campbell Soil Culture Pub. Co. 1914

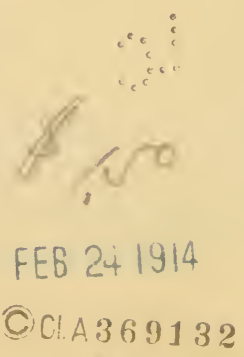




\section{CONTENTS}

CHAPTER

PAGE

I. Introduction . . . . . . . . . 9

II. Habits and Types . . . . . . 15

III. Seed Improvement • . . . . . 29

IV. Soil, Climate and Cultivation . . 38

V. Wheat Seeding and Cultivation . . 59

VI. Harvest and Yield . . . . . . 70

VII. Threshing and Marketing . . . . 81

VIII. Wheat Enemies . . . . . . 92

IX. Maintaining Soil Fertility . . . 100

X. Wheat on the Pacific Coast . . . 122

XI. Wheat Growing in Canada . . . 134

XII. Culture Methods . . . . . . 146

XIII. Rotation of Crops . . . . . 157

XIV. Seeding Machinery . . . . . 163

\section{APPENDIX}

Individual Practices

How to Run a Binder . . . . . . . 187

Index . . . . . . . . . . . . 192 



\section{PREFACE}

This little book deals largely with the wheat culture of the Great Plains region of the United States and Canada, but the writer has attempted also, to give some general information on the raising, marketing, handling and use of the wheat crop. This book is not technical but treats the subject in a practical way and is written especially for the study and use of those who are engaged in wheat farming.

During my fifteen years experience in wheat farming, five years in North Dakota and ten years in Kansas, in connection with the state agricultural colleges, I have gained some special knowledge of culture methods and practice which may be of value to others who are engaged in the wheat growing business. In preparing the following pages I have also consulted other authorities on the subject and have frequently quoted from wheat books and bulletins. I wish to refer especially to "Cereals in America" by Thomas F. Hunt, and the "Book of Wheat" by Peter Tracy Dondlinger as being among the best authorities on the subject. For the illustrations shown in figures 1, $4,6,7,8,11,12,13,14,16$ and 22, I am indebted to the courtesy of the Kansas experiment station and the Ft. Hays branch station.

Perhaps this book is hardly worthy of a formal dedication, but I wish to present it with my heartiest good wishes to the dry land farmers of the 
western plains and the Pacific slope, hoping that it will help them to solve the great problems of western agriculture, help to make dry farming profitable and permanent and thus establish the homes and happiness of those splendid men and women of the great west.

\section{A. M. TEN EYCK,}

Iowa State College, Ames, Iowa.

Jan. 1, 1914 


\section{CHAPTER I}

\section{INTRODUCTION}

Wheat is the world's greatest cereal crop. Both corn and oats exceed wheat in bulk, but by weight the four great cereals rank in the order of their production as follows: Wheat, corn, oats, rice. It may be of interest to observe that in bulk or bushels oats ranks first, corn second, wheat third, and rice fourth. But as a food for human consumption, wheat ranks first, rice second, corn third, and oats fourth. Rice and wheat were the grains of the early eastern civilizations. Corn was the great food plant of the natives of Central and North America. Rice is today the chief food of half of the people of the earth.

\section{THE WORLD'S PRODUCTION OF CEREALS}

In the United States the order of production is in part reversed, corn ranking first, wheat second, and oats third by weight; but in bulk, oats ranks second and wheat third. Rice is grown to only a limited extent in the United States but it is the principal grain crop of China, India, Japan and other Asiatic countries. The agricultural year book gives the total yield of these grains in the world and in the United States in 1910 as follows: 
United State's Crop

1. Wheat... $695,443,000$ bushels. .

2. Corn . . . 3,125,713,000 bushels . . .

3. Oats ..... 1,126,765,000 bushels . .

4. Rice..... . ${ }^{*} 710,289,000$ pounds . . $190,186,068,000$ pounds ${ }^{*}$ Crop of 1909.

The world's crop of wheat in 1910 was produced as follows:

Bushels

North America. 855,433,000

South Amərica. $159,753,000$

Europe ...... 1,952,531,000

Total

\begin{abstract}
Bushels $508,152,000$

Asia $72,886,000$ Africa

Australasia $102,197,000$ $3,650,952,000$
\end{abstract}

\section{LARGEST WHEAT PRODUCING STATES}

The states producing more than 25,000,000 bushels of wheat in 1910 with the average yields per acre for the ten year period, 1901-1910, are given as follows:

\begin{tabular}{|c|c|c|}
\hline State & $\begin{array}{c}\text { Total Production } \\
1910 \\
\text { (Bushels) }\end{array}$ & $\begin{array}{l}\text { Average per Acre } \\
\text { Yield 1901-1910 } \\
\text { (Bushels) }\end{array}$ \\
\hline 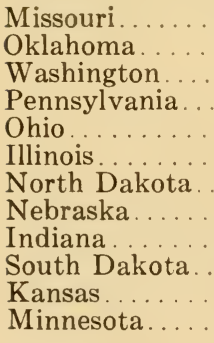 & $\begin{array}{l}25,130,000 \\
25,363,000 \\
25,603,000 \\
27,697,000 \\
31,493,000 \\
31,500,000 \\
36,105,000^{*} \\
39,515,000 \\
40,981,000 \\
46,720,000 \\
€ 2,068,000 \\
94,080,000\end{array}$ & $\begin{array}{l}14.31 \\
12.56 \\
22.64 \\
16.93 \\
15.95 \\
15.66 \\
12.08 \\
17.87 \\
15.19 \\
12.75 \\
13.64 \\
13.55\end{array}$ \\
\hline United States. & $6 \subseteq 5,443,000$ & 14.23 \\
\hline
\end{tabular}

*Drouth cut the North Dakota crop in two in 1910.

The wheat countries, producing more than $100,000,000$ bushels in 1910 are given in order of their total production as follows: 
Bushels

Russia . . . . . . . 755,695,000

United States. . . 695,443,000

British India . . . . 357,941,000

France.........268,364,000

Austria Hungary .255, 162,000

Italy . . . . . . 153,337,000
Bushels

Canada......... 149,990,000

Germany........141,884,000

Spain ..........137,448,000

Argentina.......131,010,000

Roumania

\section{PRODUCTION OF WINTER AND SPRING WHEAT}

Wheat is most largely grown in cool, temperate climates. Its winter growing habit and early maturing season make it especially well suited to the higher and drier sections of the middle and western states. The varieties adapted to fall seeding are grown in the warmer wheat sections, but there are many spring sorts adapted to the colder climates.

Of the states named, North Dakota, South Dakota, Minnesota and. Washington grow principally spring wheat. The other states grow largely winter wheat. In the United States much more winter wheat than spring wheat is grown. The production of each in 1911 is given in the year book as follows:

Winter wheat...........430,656,000 bushels

Spring wheat............190,682,000 bushels

Total . . . . . . . . . .621,338,000 bushels

DISTRIBUTION OF THE WHEAT CROP OF THE UNITED STATES

The amount of wheat exported by the United States has decreased rapidly during the last ten years, even while our production was increasing. This is due to the great increase in population. The distribution and consumption of wheat in 
the United States for the past fifteen years is shown in Table I. If the present rate of increase in the home consumption of wheat continues our surplus for export will be wiped out in six years, and the United States will become an importer of wheat and flour rather than an exporter.

\section{WHEAT PRODUCTION IN CANADA}

In 1912, Canada produced 199,236,000 bushels of wheat on $9,758,400$ acres or an average yield of 20.42 bushels per acre. A somewhat larger crop was reported for 1911, viz., 215,918,000 bushels. Most of this wheat was grown in the western provinces, Manitoba, Saskatchewan and Alberta. The total production of these three provinces is placed at $183,322,000$ bushels in 1912 and 194,083,000 bushels in 1911. The acreage and production of each province in 1912 are given as follows:*

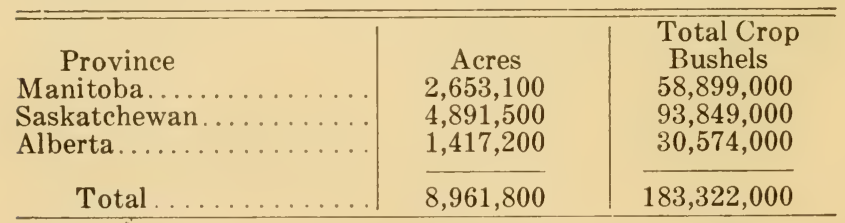

The total acreage grown in the three provinces in 1911 was reported as $0,301,293$ bushels.

The wheat acreage of Canada has doubled in five years, and the average yield per acre has also increased, exceeding the average acre-yield in the United States by more than five bushels per acre

*Total yield for Canada 1913, 210,998,800 bushels. 


\begin{tabular}{|c|c|c|c|c|}
\hline & \multicolumn{3}{|c|}{ 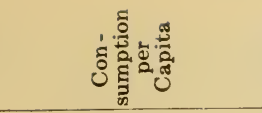 } & 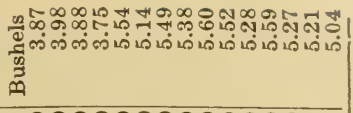 \\
\hline & \multirow{7}{*}{ 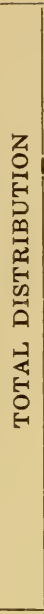 } & \multicolumn{2}{|c|}{ 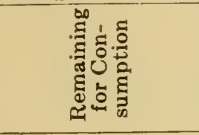 } & 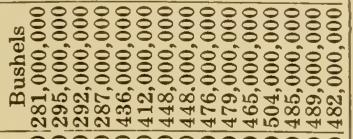 \\
\hline$\frac{\alpha}{4}$ & & \multicolumn{2}{|c|}{ 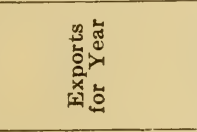 } & 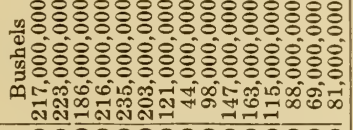 \\
\hline s & & \multirow{4}{*}{ 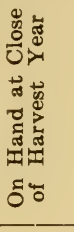 } & \multirow{2}{*}{ 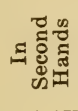 } & 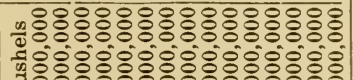 \\
\hline & & & & 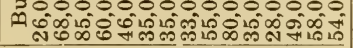 \\
\hline Z & & & 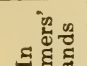 & 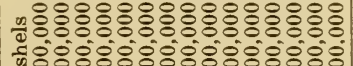 \\
\hline & & & 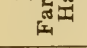 & men min m \\
\hline 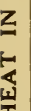 & & \multicolumn{2}{|c|}{.ृँ } & 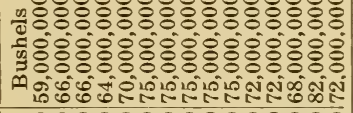 \\
\hline$\frac{1}{6}$ & \multirow{4}{*}{ 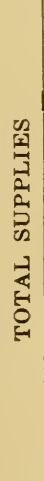 } & \multicolumn{2}{|c|}{ 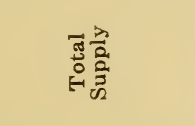 } & 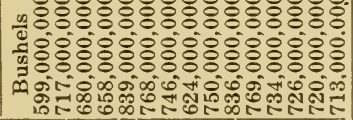 \\
\hline 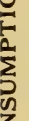 & & \multirow{2}{*}{ 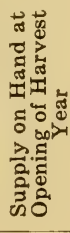 } & 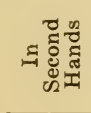 & 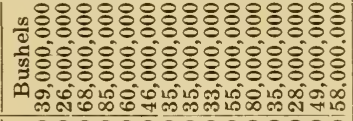 \\
\hline $\begin{array}{l}0 \\
0 \\
\\
\end{array}$ & & & 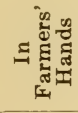 & 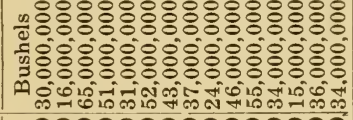 \\
\hline בֶ, & & \multicolumn{2}{|c|}{ 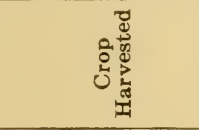 } & 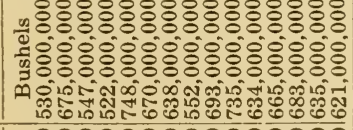 \\
\hline$\frac{\pi}{2}$ & \multicolumn{3}{|c|}{ 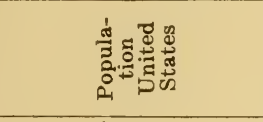 } & 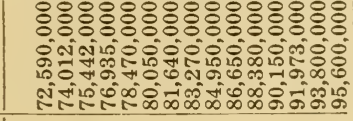 \\
\hline$\stackrel{\frac{1}{12}}{\frac{0}{1}}$ & \multicolumn{3}{|c|}{ 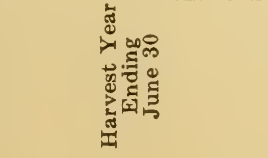 } & 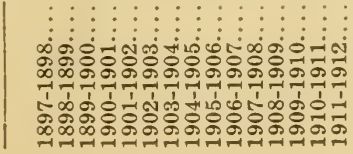 \\
\hline
\end{tabular}


in 1911 and 1912. This increased acre-yield is due in part to favorable seasons and also to the practice of better culture methods and to the planting of adapted, early-maturing varieties.

There has been an unprecedented development of the Canadian northwest since 1903. If this rate of development continues for the next ten years, Canada will rank with Russia and the United States as one of the three greatest wheat producing countries of the world. It is estimated that there are in the three western provinces about 180,000,000 acres available for cultivation, the greater part of which is adapted to wheat growing. Of this area, not more than $6 \%$ is at present under cultivation. There is enough good wheat land in the western provinces alone when this land is brought under cultivation, to produce two billion bushels of wheat annually, and allow one-third of the land to lie fallow each year. To the north of Alberta and Saskatchewan in the territories of Mackenzie, Keewatin, Ungava and Yukon lies an immense area of more than 900,000,000 acres, some of which will eventually be cultivated in wheat, as shown by the fact that wheat has already been successfully grown at several points within this region. 


\section{CHAPTER II \\ HABITS AND TYPES}

\section{BOTANICAL RELATIONS}

Wheat belongs to the family of true grasses (Gramineae). The grass family is a large and very important one because of the great number of species that supply both grain and hay. They include all the standard varieties of small grains, corn, grain-sorghums and all grasses used for hay and fodder. The cultivated grains and grasses furnish the staple foods for man and beast the world over.

\section{HABITS AND STRUCTURE OF PLANT}

The leaves of wheat are slender and ribbon-like and attached to the stem at the nodes in the form of a sheath covering the internodes. The stems are round and usually hollow; height, three to five feet. You have noticed the mass of leaves clustered close to the ground when the plants are young and observed how quickly they are carried up off the ground when the wheat begins to stem or "boot." Fall sown grains produce only leaves until early spring, then the plant stems lengthen, not only by growing at the tip but the internodes grow in length also. When a field of grain is blown down or lodged, it may "straighten up" due to the fact that the cells on the under side of the stem increase and grow faster than the cells on the upper side. Also, renewed growth occurs at the nodes to strengthen the stem. 


\section{FLOWER AND FRUIT}

Wheat flowers have pistils and stamens but no colored showy parts. The stamens and pistils are protected by greatly shortened leaves called glumes or palea. Short spikelets containing one to three small flowers are closely attached to the fruiting stem (rachis) and form a close compact head or spike. It has been found that the anthers shed their pollen and the stigmas become moist before the flowers open, and are thus normally close fertilized. There is probably little or no natural crossing in wheat. Hays found that wheat flowers open and close in the early morning, the operation consuming only twenty to forty minutes.*

\section{GERMINATION AND ROOTS}

When the seed sprouts, the shoot grows upwards and forms a second growth of roots that are permanent, the first set eventually dying. The length of the first shoot varies according to the depth of soil covering. If the seed is covered deeply it will grow to within one to two inches of the surface before forming the permanent roots. Too deep planting may therefore weaken the plant and reduce the growth and yield. The root system of wheat and all other cereals and grasses consists of slender, much-branched rootlets. There is no a tap root.

${ }^{*}$ Minnesota Experiment Station Bulletin No. 62. 


\section{STOOLING}

In wheat and nearly all cereals and grasses more than one stem is formed from each seedling. This is called stooling or tillering. It is a characteristic to be encouraged in small grains. It is due to the branching of the stem below the ground just after the permanent roots are formed. Each branch soon forms its own roots. Cool, damp weather during the early growth of the grain favors stooling, as does also a fertile soil. Furrow planting (listing) of small grains seems to favor stooling, but in the case of corn it appears to retard the tendency to "sucker." Thick seeding checks the vigor of individual plants and reduces stooling. However the thickly planted grain may mature earlier and more evenly, and may make larger yields. The character of soil, the moisture supply, temperature and altitude affect the stooling habit, the cooler drier climates being favorable. The amount of seed sown per acre varies. Thin seeding gives hardier, stronger plants, larger stools with stronger and deeper feeding roots, and is preferred in dry climates and for the less fertile soils.

\section{THE GRAIN}

The wheat grain is a dry, indehiscent fruit which has the pod and a single seed incorporated in one body. Such a fruit is called a caryopsis. The grain is about two and a half times as long as it is broad, with a hairy apex, oval in shape but slightly compressed laterally, with a furrow or groove on the side opposite the embryo caused by 


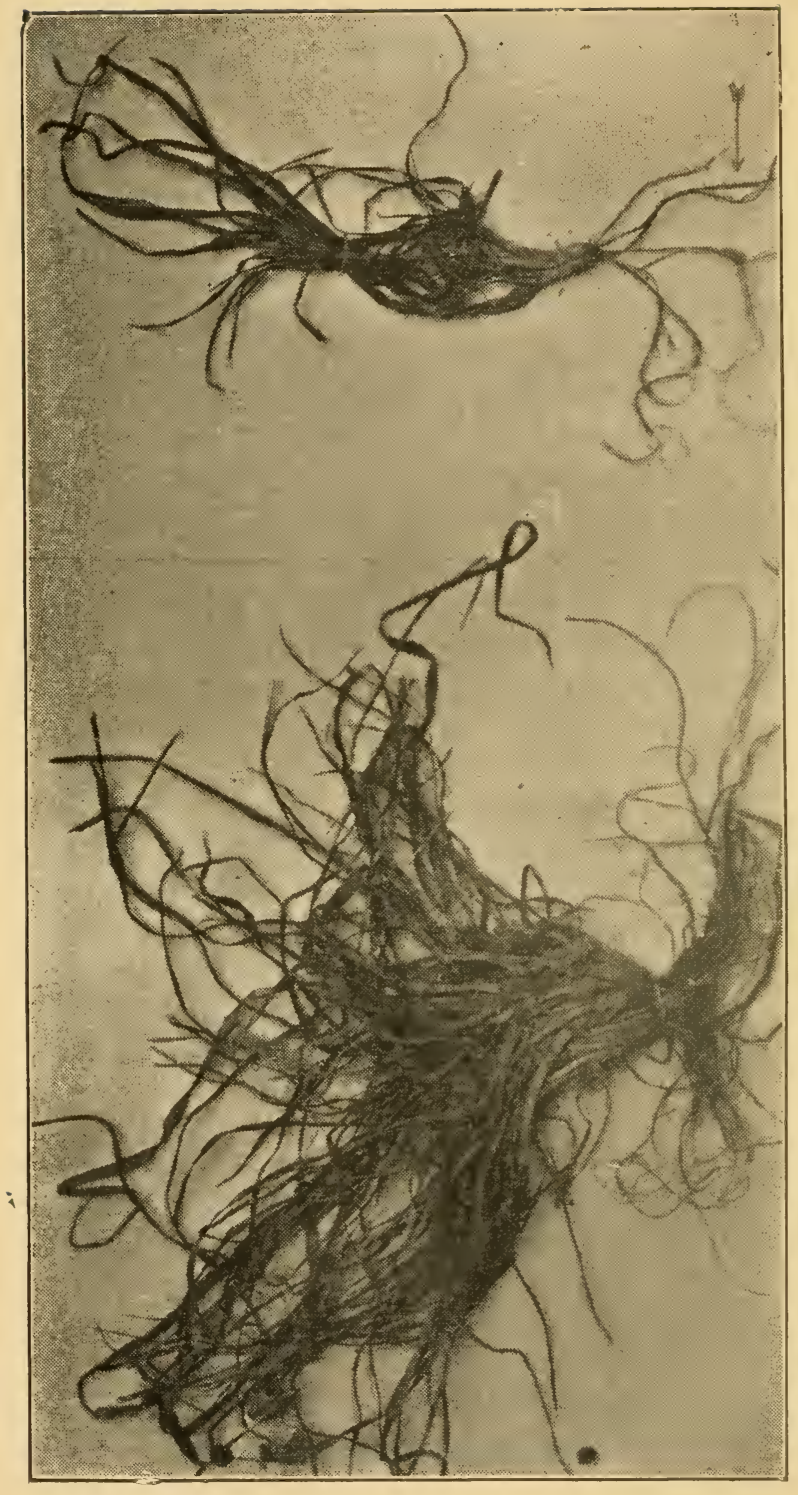

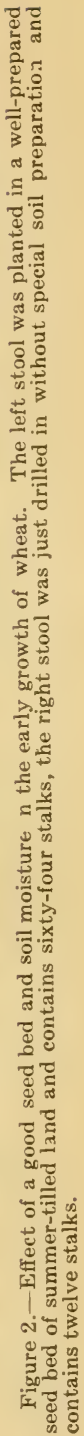


a deep infolding of the pericarp or bran. The physical parts of the wheat grain and their average proportions are as follows:

Seed covering or bran..................... $5.0 \%$

Aleurone layer enclosing endosperm and embryo.

$3.5 \%$

Embryo

Endosperm or main portion of grain

6:5\%

The endorsperm is the portion from which the flour is made. It is made up largely of starch cells but contains also about 8 to $10 \%$ of gluten.

The aleurone layer is composed of a single row of large cells known as aleurone or gluten cells, but this part is not included in the flour.

The bran is made up of six layers of cells, the three outer layers being the pod or pericarp, and the inner layers the coverings of the ovule or seed proper.

The embryo may be divided into the vegetative portion which contains the miniature first leaves and roots of the new plant, and the scutellum or absorbent organ which at germination dissolves the substance of the endosperm and transfers it to the vegetative portion. The embryo contains a high percentage of ash, about $16 \%$ of fat, $33 \%$ of protein and considerable quantities of carbohydrates, mainly sugar.

\section{VARIATION IN SIZE}

Bessey estimates the cubic content of a wheat grain to be twenty to thirty cubic millimeters. Richardson found an average of 12,000 grains in a pound of wheat. There were variations of 8,000 to 24,000 grains to the pound. Thus one bushel of seed in one case would be equivalent 
to three bushels in the other, so far as individual grains are concerned. The standard (and generally legal) weight per bushel $(2,150.42 \mathrm{cu}$. in.) of wheat is sixty pounds. The measured bushel may vary in weight from fifty to sixty-five pounds. The color of the grain varies from light yellow to dark red. Hardness of grain and high nitrogen content are usually associated with a deep red or clear amber color.

\section{SPECIES AND VARIETIES}

There are seven or eight different species or sub-species of wheat. Only one of these types is generally grown in the United States. This is the common milling wheat of the world, the botanical name of which is Triticum sativum vulgare. It includes practically all of the winter wheat and most of the spring wheat grown in this country. The species Triticum sativum durum, commonly called durum wheat or macaroni wheat, which is used largely in the manufacture of macaroni, also succeeds well as a spring wheat in the drier portions of the Dakotas, Nebraska and Kansas.

There are several divisions of the species Triticum sativum vulgare such as the hard and soft wheat; and either of these may be divided into several groups as red hard wheat, white hard wheat, red soft wheat and white soft wheat. Furthermore, there are bearded and beardless types of each of these groups, and while some varieties have smooth chaff others have a rough or velvety chaff. There are red chaff and white 
chaff varieties also. The varietal names number into the hundreds, and often there is no marked characteristic to distinguish the variety. Carleton has tested, studied and described 245 leading varieties of wheat out of one thousand or more samples secured from all parts of the world.*

\section{TYPES OR GENERA}

The wheat genus includes five other types as follows:

Einkorn........... Triticum monococcum

Spelt................. Triticum sativum spelta

Emmer............. Triticum sativum dicoccum

Poulard wheat....... Triticum sativum turgidum

Polish wheat......... Triticum polonicum

These types of wheat were largely cultivated in ancient times in eastern Asia, Egypt, Greece and Italy. They are usually hardy and drouthresistant, and are grown to a limited extent today in dry areas and cold climates but more for feed for livestock than for human food. These grains produce an inferior type of flour.

It may be of interest to note here that the "Alaska" wheat, much advertised a few years ago by promoters as a wheat of wonderful yielding power, belongs to the Poulard group. It is a variety having branching spikes and is also called "Multiple Head Wheat," "Egyptian Wheat" and "Wheat of Miracle." Thomas F. Hunt in his "Cereals in America," speaks of this variety as a "sport having no value."

*United States Bulletin No. 24, Division of Vegetable Physiology. 


\section{THE BEST VARIETIES TO PLANT}

A large number of varieties of winter wheat have been tested at the Kansas experiment station during the past ten years. Among the better producing varieties as shown by these trials are Kharkof, Crimean, Turkey Red, Malakoff, Ghirka, Theiss, Weisenberg, Defiance, Bearded (winter) Fife, Fultz, Fulcaster, Mediterranean, Currell and Zimmerman.

It is important to observe that of the varieties named, the Ghirka is the only hard red wheat with bald or beardless heads which has proved to be a good producer. The last five varieties named are of the soft wheat type; the Fultz, Fulcaster, and Mediterranean are bearded, the other two are beardless. The first nine varieties named are the hard red wheat, and all of these but the Ghirka are of the bearded Turkey type generally grown in Kansas and throughout the western winter wheat belt. The adaptation of varieties varies for different conditions of soil and climate. The reader is referred to his state experiment station for information regarding best producing varieties for a particular state or locality.

\section{TYPES OF SPRING WHEAT}

The more important types of spring wheat are the Fife, Bluestem, Velvet Chaff, Durum and Club Head. There are a number of minor varieties of each of these types. Fife is a beardless, smooth chaff, hard wheat. There are both red and white 
grained varieties. Bluestem is a beardless velvet chaff wheat with grain of medium hard quality and reddish color. Velvet Chaff is a trade name for several varieties of bearded soft wheat. Club Head is a soft white wheat with short, stubby, very compact heads, usually beardless, with smooth chaff. All of the types and varieties named above except the Durum wheat, belong to the group "Common Wheat," Triticum sativum vulgare. The Club Head is usually classed as a sub-species, Triticum compactum. Carleton has given the natural groups of wheat and the names of all leading varieties adapted for growing in the different wheat districts of the world.*

\section{MILLING VARIETIES}

Two general types of milling wheat are grown in the United States, hard wheat and soft wheat. The great plains region is particularly adapted for growing hard red wheat of excellent quality, the best bread making wheat in the world. Nearly half of the wheat grown in the United States is grown in the north central states west of the Mississippi river, viz: Minnesota, Iowa, Missouri, North Dakota, South Dakota, Nebraska and Kansas. These states are mainly in the hard wheat belt, as are also Oklahoma and Texas. The Rocky mountain states also grow some hard wheat. Soft wheat is grown in the more humid climates, mainly in the north-eastern and north central

*United States Bulletin No, 24, Division of Vegetable Physiology. 
states east of the Mississippi river, and on the Pacific coast. The red soft wheat is grown in the eastern states, and the white soft wheat is grown mainly in Washington, Oregon and California.

\section{HARD AND SOFT WHEAT CHARACTERISTICS}

Hard wheat has a grain of a more or less clear amber color. When cut, the texture appears very compact and firm. Soft wheat has an opaque color, the kernels are usually plumper and lighter in weight than hard wheat, and when broken the grain presents a white, starchy appearance. It usually contains less gluten than a good quality of hard wheat, and is deficient in gliadin, the

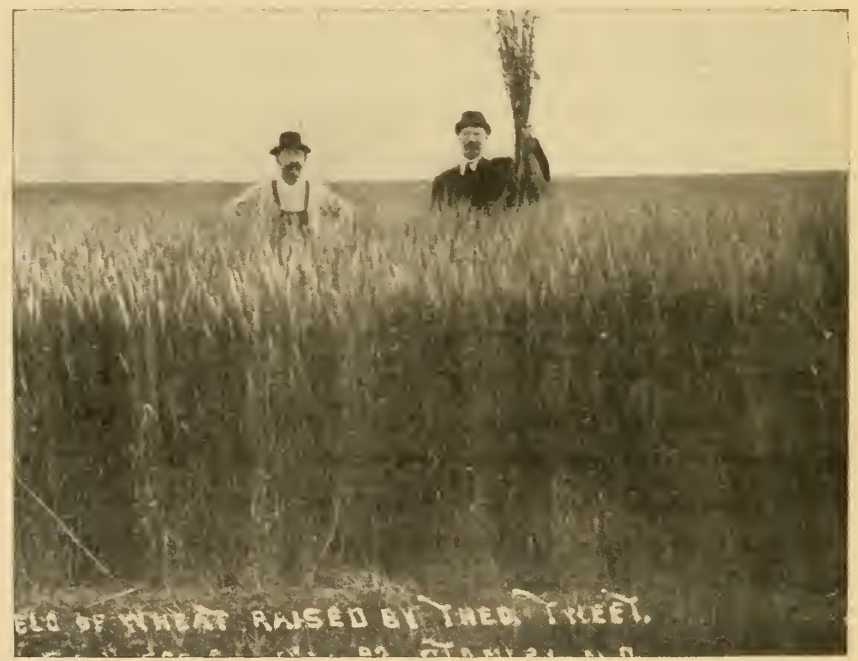

Fig. 3.-A field of beardless spring wheat, North Dakota. 
plastic part of gluten which gives the tenacity to dough and affects its rising quality. The best quality of light bread cannot be made from soft wheat flour. Hence, soft wheat flour is used more largely for pastries. But a certain proportion of soft wheat is used to blend with hard wheat in the manufacture of the best patent flour.

\section{VARY WITH CLIMATE}

The hardness and texture of the grain may vary not only in different varieties but with the climate and season in which the wheat is grown. Hard wheat varieties which characterize dry regions become softer when grown in moist climates. It becomes necessary therefore, in the more humid sections where hard wheat is grown for the farmers to change seed wheat every few years, securing the new seed from the drier sections farther west and north where the best quality of hard wheat is produced. Recent experiments in breeding wheat indicate that the hard character may be maintained in the more humid sections by "head-row" breeding by which pedigreed strains are produced from a single head or plant which has retained the character of hardness even under the adverse conditions.*

\section{DURUM OR MACARONI WHEAT}

Durum wheat is a bearded type of wheat of which there are several distinct varieties, varying in color of chaff, smoothness of glumes, etc., but

*Bulletin No. 156 Kansas Experiment Station, by Roberts \& Freeman. 
all having the characteristically hard, flinty grain which is particularly adapted to the manufacture of macaroni; also flour from this wheat is now being used to make bread, which is somewhat darker in color than bread from patent flour, but it is nutritious and has an agreeable taste and some people prefer it to ordinary wheat bread. As a spring wheat it is rapidly coming into use in the northwestern states. It is more hardy and more productive than ordinary spring wheat. Brought from the dry, hot steppes of Turkestan and southeastern Russia where it has been grown for hundreds of years, it is decidedly a dry farming crop and it is proving to be hardy and well adapted to the severe climate of the northwest. It is not so safe a crop and is less productive than winter wheat in the middle west and in the southwest. Spring wheat is not well adapted for growing in Kansas and the states farther south.

\section{MILLING PRODUCTS}

Wheat is almost exclusively used for the production of flour from which various forms of human food are made. Varying with the kinds, quality and grade of wheat and the milling processes, the out-turn of mill products are about as follows:

Flour.

Bran

65 to $80 \%$ (usually 70 to $75 \%$ )

Shorts and middlings. 5 to $8 \%$

The by-products of wheat are highly prized as food for all classes of livestock, yet within the memory of persons now living (1913) the bran 
spout of grist mills emptied its contents into the river.

Flour is usually run in two or more grades:

1. Patent flour, a clear white grain.

2. Baker's flour, slightly yellow in color.

3. Low grade flour, dark, soft grain and lumpy, containing particles of bran.

Graham flour is unbolted wheat meal or the whole wheat ground into a meal, nothing being removed. Entire wheat flour is wheat meal from which the coarsest of the bran has been removed.

The weight per bushel is a test in part of the milling qualities of wheat. "Heavy" wheat tests fifty-nine pounds or more per bushel. The lighter wheat gives a larger out-turn of the less valuable products, bran and shorts. Common causes of light wheat are unadapted seed, lodging, premature harvesting, dry hot winds, attacks of insects and diseases (smut and rust), sprouting in the shock, etc.

COMPOSITION OF WHEAT AND ITS PRODUCTS

The value of wheat as a human food is due to its palatability and the attractiveness and great variety of forms which can be made from it, as well as to its abundant supply of nutritious substance. The composition of wheat and its products is given as follows:*

*Hunt's Cereals of smerica, page 113. 


\section{TABLE II}

CHEMICAL COMPOSITION OF WHEAT AND ITS PRODUCTS

(PARTS IN 100)

\begin{tabular}{|c|c|c|c|c|c|}
\hline & Wheat & $\begin{array}{l}\text { Fatent } \\
\text { Flour }\end{array}$ & Bran & Shorts & $\begin{array}{l}\text { Mid- } \\
\text { dlings }\end{array}$ \\
\hline Water. & & 11.48 & 11.9 & 11.8 & 12.1 \\
\hline As & 1. & .39 & .8 & 4.6 & 3.3 \\
\hline tein $(\mathrm{W} \times 6.25)$. & 14.35 & 12.95 & 15.4 & 14.9 & 15.6 \\
\hline Crude fiber. . . . . . . . . & 1.68 & .18 & 9.0 & 7.4 & 4.6 \\
\hline $\begin{array}{l}\text { Nitrogen free extract } \\
\text { or carbohydrates. }\end{array}$ & 70.37 & 73.5 & 53.9 & 56.8 & 60.4 \\
\hline 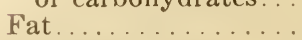 & 2.74 & 1.45 & 4.0 & 4.5 & 4.0 \\
\hline Phosphoric acid.... & .82 & .18 & 1.22 & & $\cdots$ \\
\hline
\end{tabular}

\section{AMOUNT OF BREAD FROM FLOUR}

The value of flour depends upon the amount and quality of bread which it will produce. The amount of bread also depends upon the condition of baking as regards the amount of water in the dough, size of loaves, temperature of oven, etc. The United States department of agriculture, chemical bulletin No. 4, reports the amount of bread baked from different flours handled alike, as varying from 129 pounds to 140 pounds from each hundred pounds of flour. The flour with the least percent of nitrogen produced the smallest percent of bread. Each pound of wheat will produce about a pound of bread, since the percentage of flour in wheat averages about $72 \%$. 


\section{Chapter III \\ SEED IMPROVEMENT}

\section{ADAPTATION OF SEED}

Planting good, pure seed of well bred wheat of the type or variety best adapted to the local conditions is one of the most important factors in successful wheat culture. It is well for the grower to keep in touch with the state experiment stations where the varieties are being continually tested and improved in order to secure the best seed of the best variety for his state or locality.

The western plains south of the Dakotas is the land of the hard red winter wheat, and the Turkey or bearded type is generally best adapted for growing in this region, but there are different varieties or strains, some of which are superior to others in quality, hardiness and productiveness. The Kharkof (Turkey) wheat has been proved to be one of the best producing varieties at the Kansas experiment station.

\section{A MONEY CROP}

Wheat is the great "money" crop of a large part of the dry farming area, yet it is not especially a drouth resistant crop. Its success is more largely due to the fact that the crop grows and matures during a part of the year when drouth and hot winds are least apt to prevail. On this account also it makes advantageous use of the moisture stored in the soil by summer tilling and by 
careful seedbed preparation. It is true that western farmers have been depending too much upon a single crop, and continuous wheat cropping is rapidly exhausting the soil fertility. The writer would not discourage the growing of wheat on this account but rather encourage the practice of better farming methods, described in these pages, by which more wheat of better quality shall be produced on fewer acres without depleting the fertility of the soil.

Farmers throughout the hard winter wheat belt are urged to plant hard red winter wheat of the Turkey type and to secure seed of an improved variety. It will pay to plant well bred seed of the best producing varieties, as has been proved by the tests at the experiment stations and the actual experience of farmers.

\section{CLEANING AND GRADING}

It is advisable to clean seed grain of all trash and very light kernels. Heavy, plump seed germinates quickly, grows more vigorously, and gives greater assurance of a regular stand and a large yield. However, carefully graded, shriveled grain of a hardy, adapted variety may often be preferable for planting to well developed seed brought from a different climate. There are many good makes of fanning mills and grain graders. The writer prefers for general use the ordinary fanning mill with proper sieves and screens for removing weed seeds and small and broken grains, and which allows for a strong blast which will remove the 
chaff and dirt and light weight kernels which are likely to be deficient in vitality.

\section{TREATMENT FOR SMUT}

If the seed wheat is infected with smut, it should be treated with a solution of formaldehyde to destroy the smut spores which adhere to the wheat kernels. (See page 96 for full treatment.)

Treating for smut and careful grading of seed may not only increase the yield, but by such a practice it is possible to maintain a good variety of wheat and improve both the yield and quality of grain adapted to the soil and climate. All farmers should take these precautions to increase their annual yields and to maintain and improve their seed wheat, but more rapid and more permanent improvement may be secured by individual selection of plants and careful breeding.

\section{WHEAT IMPROVEMENT}

The best varieties of cereals are strains that have been continuously and carefully selected and thus adapted to the soil conditions and acclimated to the belt in which they are grown. The Turkey wheat owes its hardiness and adaptation for growing in our western plains region largely to the training which it has received on the steppes of Russia and Turkestan. The Russian wheat introduced into the hard wheat belt of this country has a decided advantage over the soft wheat types of the eastern states which are not adapted to dry climatic conditions. It is doubtful, however, 
if new importations from the old world will give any advantage over the best local strains which have been developed in our western states from the early importations.

\section{FROM DRY TO MOIST CLIMATE}

High yielding varieties of wheat from moist climates generally give lower yields in dry climates than acclimated or native sorts, and vice versa, when the conditions are extreme. The quality of hard wheat in the more humid sections of the hard wheat belt is improved by planting seed grown under drier climatic conditions, and if the change in climate or soil is not too great, the yield may not be decreased. Such changes of seed from a dry section to a moister climate should be made along the same latitude or from the north rather than from the south because of the later maturing ing season of the southern grown seed. Also in changing seed, care should be taken to secure strains of the best producing varieties because of the greater inherent tendency of pure strains to produce well, even under changed climatic conditions.

\section{HEAD-ROW METHOD OF BREEDING}

The more valuable new varieties of cereals that are now being introduced have resulted from the careful multiplication of seed from selected individual plants. In the improvement of small grain, these plants are selected by a process of testing and elimination known as the "head-row" 


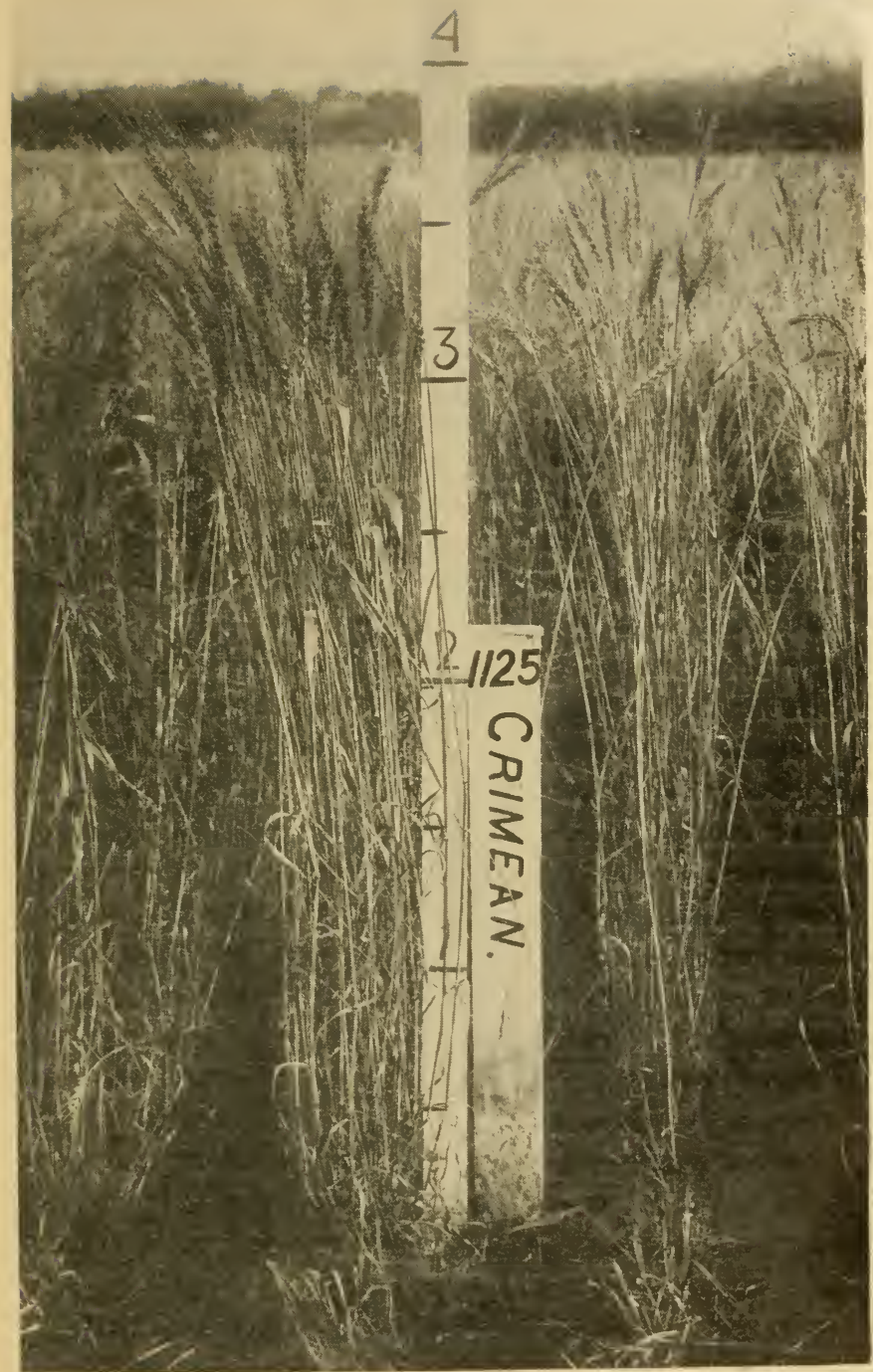

Fig. 4.-Head-row breeding, Kansas Experiment Station. Note difference in head-rows. 
method of breeding, similar to the "ear-row" method of breeding corn. A large number of the choicer heads of a high yielding, well-adapted variety are selected from the field. Many of these heads which are inferior in points of structure, yield and quality, may be discarded, but the grain from the better heads is saved and planted in individual rows in the breeding plot. The growth of the plants, hardiness, yield and quality of the grain produced by each head is thus determined and the seed from the best yielding "head-rows" may be used to plant "increase rows" on the next year "increase plots" and so on until enough seed is secured to plant a large field with the new or pedigreed strain.

This may be accomplished in a relatively short period of time. In the experience of the writer, the seed from a single head of wheat containing thirty kernels planted in the breeding row has produced a pound of good seed for planting the second season. If this pound of wheat be planted, and its product planted the next year and so on, multiplying at the rate of thirty-fold each year, it will produce thirty pounds of wheat the first year, fifteen bushels the second year, and 450 bushels the third year, or enough grain to plant 400 to 500 acres. Thus a single head of wheat planted in 1913, and its product planted each succeeding year, may produce enough seed in 1916 to plant several hundred acres of the pedigreed strain. 


\section{WORK OF THE EXPERIMENT STATION}

Pedigreed, pure bred strains of wheat or other crops are apt to be more or less locally adapted, hence local breeding centers are necessary in order to produce or secure locally adapted, high yielding varieties. The average grain grower may not take the time to make "head-row" tests to improve his seed grain but this work should be carried on at the experiment stations and the pedigreed seed increased and distributed to the farmers, who should grow it separately and keep it pure and sell the crop for seed to their neighbors, thus rapidly increasing and distributing the improved seed throughout the community and throughout the state.

This method of improving our cereal grains depends simply on discovering the great individuals which are present in every well-adapted variety, and making them the progenitors of a new or superior strain of that variety. Its practice and application are giving remarkable results. It is particularly valuable for securing rapid improvement in dry farming crops. The old method of adapting crops to the dry farming conditions by natural selection was too slow because the field-elimination process allowed many of the weaker plants to persist and bear seed each year. The new method discovers the few hardy individuals at once and eliminates the weaker types so that the increase may be only from the hardy, high-producing type. 


\section{MAINTAIN PURITY AND QUALITY OF IMPROVED SEED}

Farmers who are growing improved wheat should take great care to keep the seed wheat pure in order to continue the distribution of the good seed and to maintain the yield and quality of the grain grown on their own farms. One of the principal factors which causes deterioration in wheat is the crossing or mixing of different varieties or strains. Common sources of mixing are from volunteer wheat which occurs when fields are reseeded to wheat year after year; or mixing may occur in the harvesting or threshing where two or more varieties are grown on the same farm or on neighboring farms. Careless seedsmen and dealers also often allow the varieties to become mixed in grading and handling, so that under present conditions it is quite difficult to maintain purity in seed grain.

\section{COMMUNITY SEED}

The breeding and introduction of pedigreed strains will eventually lead to the establishment and growing of one of the best producing, pure bred varieties of each cereal grain in each community or in each locality or section with distinct climatic or soil conditions. Thus there may be established a "community seed" which will be planted by all the farmers in that community. This will be a great advantage over the present practice of growing many varieties, some of which are often poorly adapted to the local conditions. 
Because of the mixture of types and varieties and because of the want of uniformity in type and quality, all of the grain sells on the market at a relatively low price, fixed by the average quality of the crop rather than by the best grain which the locality produces. The general planting of a "community seed" would reverse these conditions and would result in larger yields and better prices and a greater. prosperity for every farmer. The farmers in each community should get together and organize and adopt a "community seed."

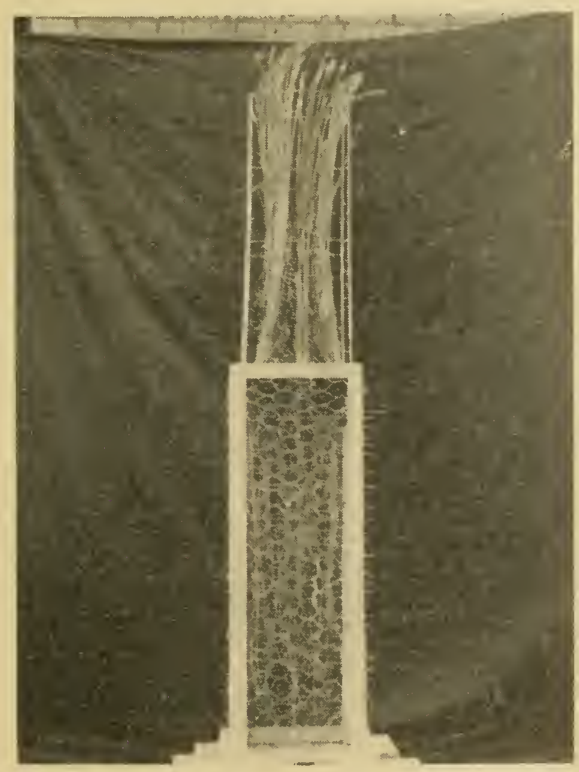

Fig. 5. - Roots of spring wheat grown under semi-arid conditions at Edgeley, North Dakota. Length of roots, four feet. 


\section{Chapter IV}

\section{SOIL, CLIMATE AND CULTIVATION}

\section{CLIMATIC CONDITIONS}

Most of the wheat of the world grows in regions with cold winters. California, Egypt and India are exceptions. On the whole, however, wheat has a very wide climatic range. It.is grown successfully in northern Russia and in the Canadian northwest, and has matured even as far north as Dawson, Alaska, $65^{\circ}$ north latitude, about two hundred miles from the Arctic circle. In the direction of the equator we find the limits of successful wheat culture between 20 and $25^{\circ}$ north and south latitude. Wheat, however, is grown successfully on the mountain plains of Columbia and Ecuador, at the equator 10,000 feet above sea level.

While wheat has a very wide geographical range, it nevertheless demands a similar climatic condition during its growing season, viz: A moderately cool and dry temperature. This is secured in the culture of the crop by the use of winter and spring varieties, and by regulating the time of seeding so that the period of growth and maturity shall occur during the cooler part of the growing season in the warmer climates.

\section{SOIL REQUIREMENTS}

Generally speaking, wheat requires a rather heavy soil, inclining to clayey. The lighter or sandy soils are not so well adapted for growing 
wheat, however soft wheat succeeds well on bottom lands of a loamy, light texture.

To produce the best quality of hard wheat requires fertile soil, land well supplied with nitrogen and rich in the mineral elements of plant food. The soil should be well balanced in fertility. If there is an over-supply of nitrogen caused by heavy manuring or by growing alfalfa or clover, there is likely to be a rank growth of straw which may lodge and the heads fail to fill, resulting in light, shrunken grain.

A fertile soil which is well supplied with organic matter and humus will produce a much larger yield of wheat under similar conditions of culture and rainfall than a less fertile soil or one lacking in vegetable matter. The humus will take in and hold more water, the organic matter acting as a sponge to absorb and retain the moisture. Also the fertile soil will supply a stronger solution of plant food, thus producing a greater growth with the same amount of water than an infertile soil. Thus the fertilized soil has the advantage in two ways: first, it absorbs and holds more moisture and supplies it to the growing crop; second, it makes better use of the soil water, the plant requiring often $50 \%$ less water because of its stronger solution of plant food than the soil low in fertility and lacking in organic matter.

Therefore, it is necessary to rotate crops, grow legumes and use manure and fertilizers to maintain and increase soil fertility, also to conserve soil moisture by proper culture methods in order to secure the largest yields of wheat. Moreover, 
special care must be given to preparing the seed and root bed in order to secure the proper soil conditions and suitable environment in the soil for germinating the seed and feeding the young plants.

\section{THE SEED BED}

The proper starting of a crop is an important factor in its production. A germinating seed requires the presence of moisture and air and a

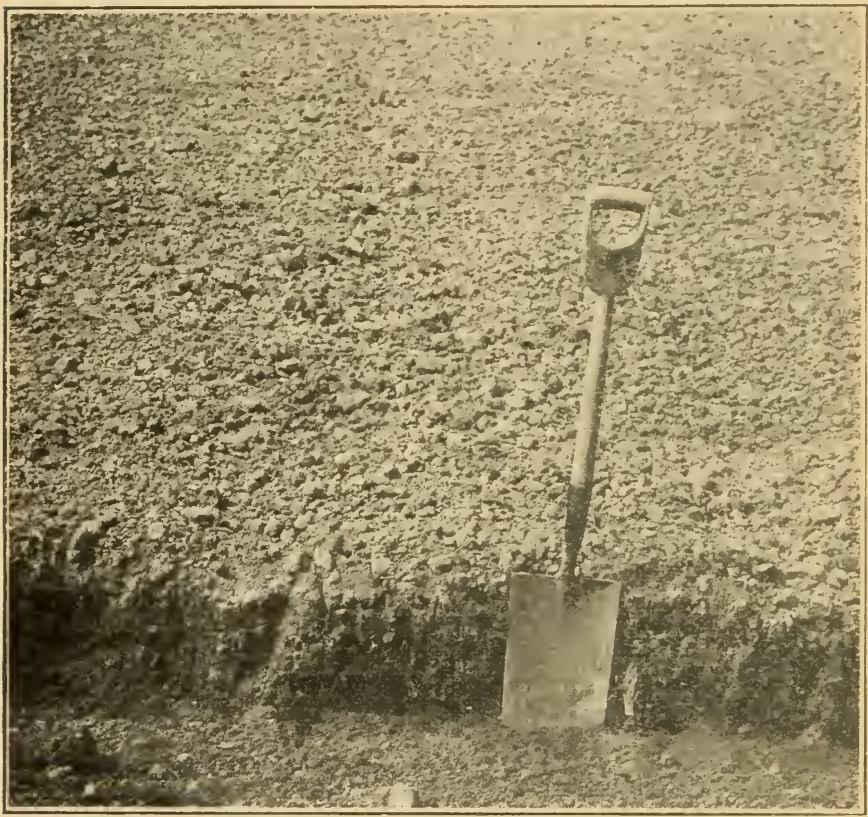

Fig. 6. - A good seed-bed. A cross-section of the plowed portion of a properly prepared seed-bed. The soil is mellow but well settled, the furrow slice making a good connection with the subsoil. 
favorable degree of heat. The plantlet is nourished at first by the food substance stored in the mother seed, but this is soon used up and the little roots quickly spread out in the prepared soil to gather the moisture and available plant food which may be found there. The young plant grows and is soon well established if the soil is fertile and the seed bed has been well prepared.

\section{HOW PLANT FOOD IS MADE AVAILABLE}

All fertile soils contain an abundant supply of plant food elements, but the compounds in which they exist are usually in an insoluble condition in the soil, a provision of nature which prevents the wasting of plant food, insures the permanency of soil fertility and the continued productiveness of the soil for ages, providing man does his part.

The plant food of the soil is gradually liberated by the action of weathering agents which cause the rock particles to break down and disintegrate, and is made available by the action of the soil bacteria which assist in the processes of decay. Thus chemical changes take place by which the insoluble plant food is gradually changed into soluble compounds, the elements of which become available to the plants when absorbed by the roots.

This "digestion" of the plant food in the soil by which it is made available to plants, at least so far as bacteria are concerned, is favored by the same conditions which are essential for the germination of seeds and the growth of plants, viz., the soil must be warm, moist and well aerated. 


\section{PROPER PHYSICAL CONDITION}

The fertility of the soil is developed by proper tillage. The physical condition of the soil is nearly always more important than mere "richness." A finely divided, mellow soil is more productive than a hard, lumpy one of the same chemical composition because it retains more moisture, renders plant food more available and affords a more congenial and comfortable place in which the plants may grow.

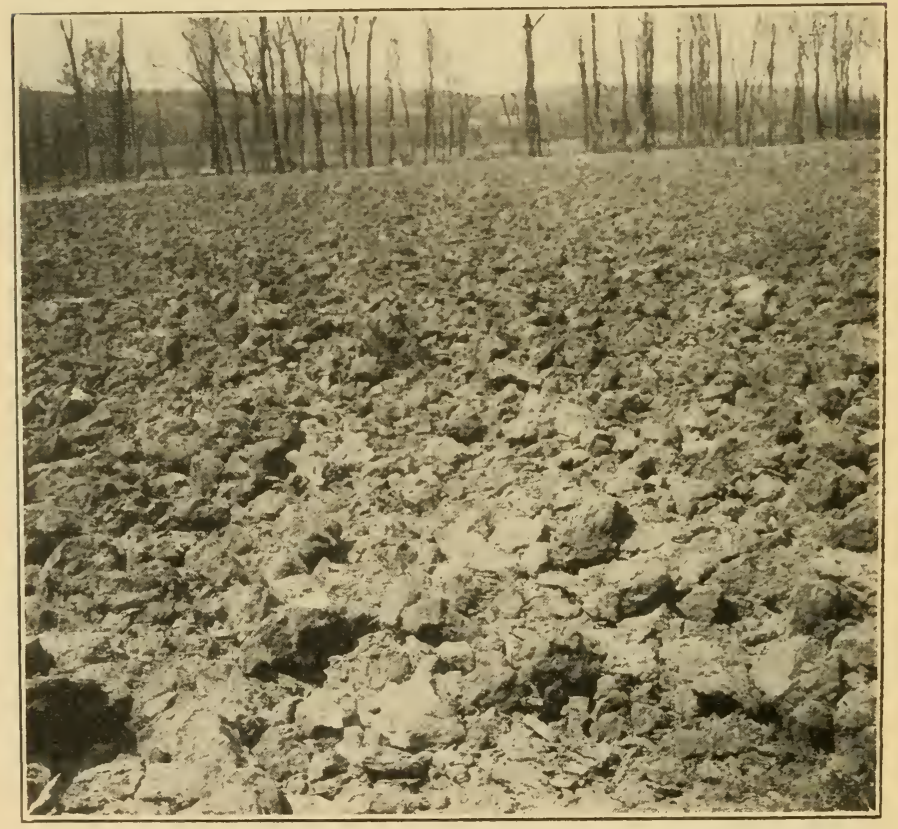

Fig. 7.-A cloddy seed-bed, plowed too dry, resulting in a very unfavorable condition. 


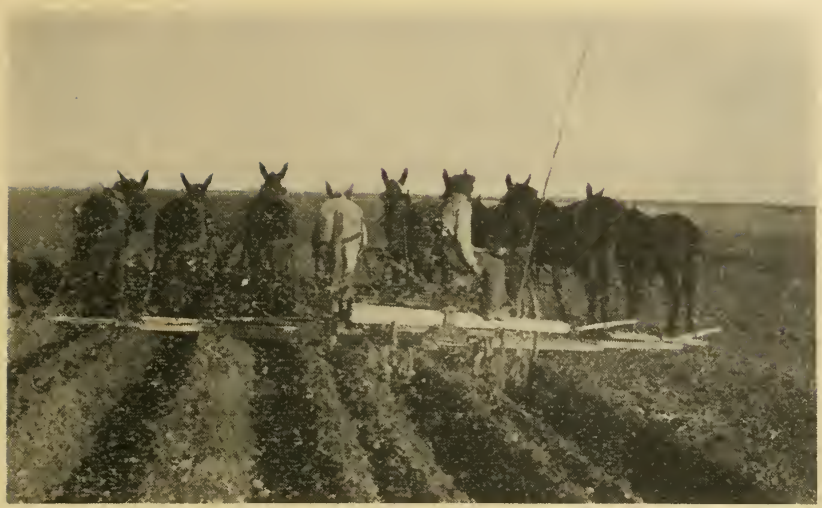

Fig. 8.-A two-row lister with eight horses listing from eight to nine inches deep, Hays, Kas., Experiment Station.

The seed bed for wheat and other small grains should be mellow at the surface, but firm and well settled below the depth at which the seed is planted. This provides the best conditions for supplying the moisture, air, and heat to the germinating seed and young plants. Deep plowing or deep listing should be encouraged, but it should be timely so that the soil may settle and fill with moisture; and such cultivation should be given after plowing or listing to secure a favorable physical condition of the seed bed.

Plowing the land early, well in advance of seeding is essential, especially in the dry farming areas of the western plains. Early plowing compared with late plowing has given largely increased yields at the Oklahoma, Kansas and Nebraska experiment stations. (See Tables III and IV.) 
FIRMING THE SEED BED

When land is allowed to lie for a considerable period after plowing before the crop is planted, the action of the rains and the necessary surface cultivation usually pack and firm the soil to a sufficient extent to make a good seed bed. The use of the subsurface packer is most essential on late spring plowing, when the purpose is to plant at once after plowing. For sowing fall wheat, the subsurface packer may be used to advantage, if the plowing precedes the sowing by a short interval. By setting the disks rather straight and weighting the harrow, a disk harrow may be used as a substitute for the subsurface packer.

MAINTAIN SOIL MULCH-DESTROY WEEDS

It is essential that sufficient and proper cultivation be given to destroy weeds. This is more

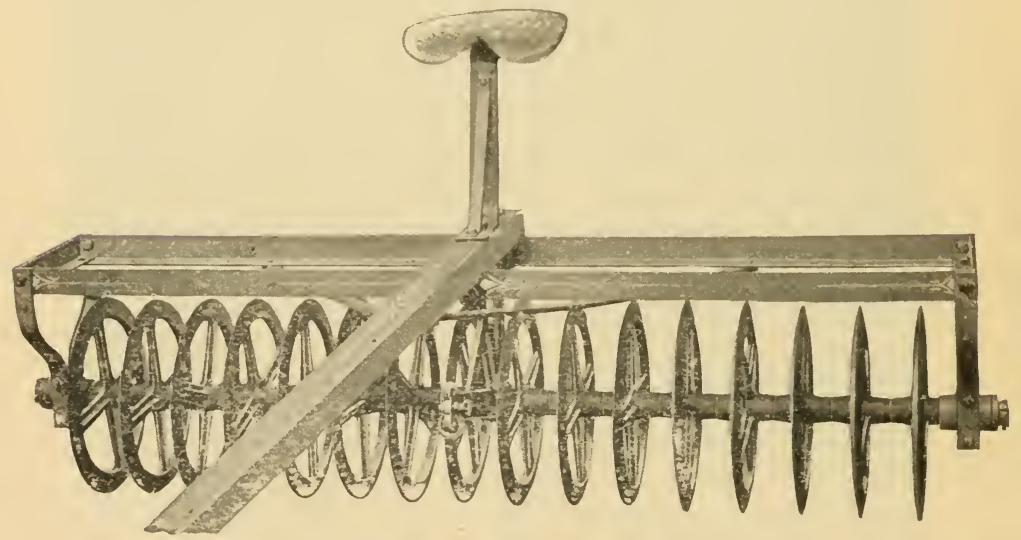

Fig. 9.-The Campbell subsurface packer. 
important than to maintain a soil mulch, since weeds exhaust both the soil moisture and available plant food. If a proper soil mulch is maintained, however, the weeds will be kept in subjection.

It is advisable to weight or ride the common harrow in order to cause it to stir the soil to a sufficient depth and prevent the slicking effect which is apt to result from light harrowing. A smooth, finely pulverized surface produced by continuous, light harrowing defeats the purpose of the cultivation, since soil in such a condition will shed heavy rains, causing a waste of the water that should have been stored in the soil. By rendering the surface too fine and compact an unfavorable seed bed is produced and the proper aeration of the soil is prevented. Thus during the interval between crops it is often advisable to use the lister or disk harrow in order to keep the surface of the soil open and mellow.

\section{CONSERVATION OF SOIL MOISTURE}

In the more humid climates it is often necessary to artificially drain the land in order to keep the soil in proper physical condition and cause it to produce profitable crops, but throughout the great plains region the conservation of the soil moisture is the first and most important problem in successful farming.

The most essential part of soil moisture conservation, the most important factor in dry farming and the one which has been most greatly neglected by our western farmers, is getting the rain water into the ground and safely storing it 
in the subsoil to be used by the growing crop. The firming and pulverizing of the soil to restore capillarity, and the proper cultivation to maintain the soil mulch are each without avail, unless there has been stored in the deeper soil a sufficient amount of moisture to supply the growing crop in times of drouth.

\section{SOIL MULCH}

The plan of producing a soil mulch to conserve the moisture has been taught and more or less successfully practiced for many years; but in very dry years this method must fail because there is no moisture stored in the soil to be conserved by cultivation.

The moisture should be caught and stored at all times of the year, but especially during the

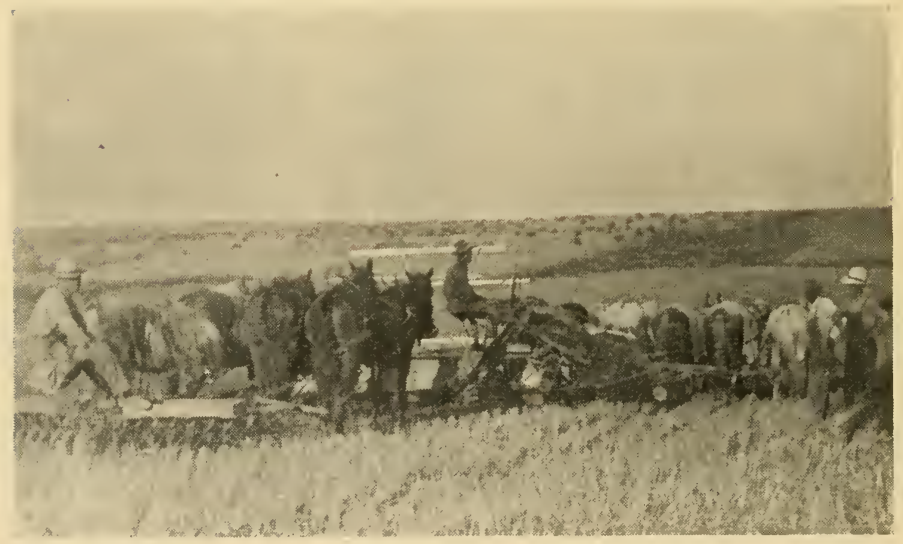

Fig. 10.-Following the binder with a disk harrow to catch and conserve moisture. 
interval between harvesting and planting. The plan should be, in the preparation of the seed bed, to put the soil in the most favorable condition to receive the rain and carry it downward into the subsoil. This is provided by disking soon after harvest or late in the fall, or early in the spring. Deep plowing a long time before planting leaves the soil mellow and rough, enlarges the water reservoir, and favors the absorption of heavy rains. But the best plan to store moisture, as determined in part by experiments conducted by the writer and the experience of a number of western farmers, is the method of listing the soil in deep furrows and high ridges soon after harvest or in the fall after the crops of corn or kafir have been cut and removed. If this work cannot be accomplished in the fall, winter listing or early spring listing is desirable on such lands as shall again be planted to intertilled crops or which may be summer fallowed in preparation for fall wheat.

\section{THE LISTING METHOD FOR WHEAT SEED BED}

In preparing the land for winter wheat list the ground with the ordinary corn lister as soon after harvest as possible. The listed furrows are run about three and one-half feet apart, very much the same as when the lister is used for planting corn. Later, when the weeds have started, the soil is worked back into the listed furrows by means of the harrow or disk cultivator. Several cultivations are usually required with a spike tooth harrow or disk in order to level the field and bring it into good seed bed condition. 


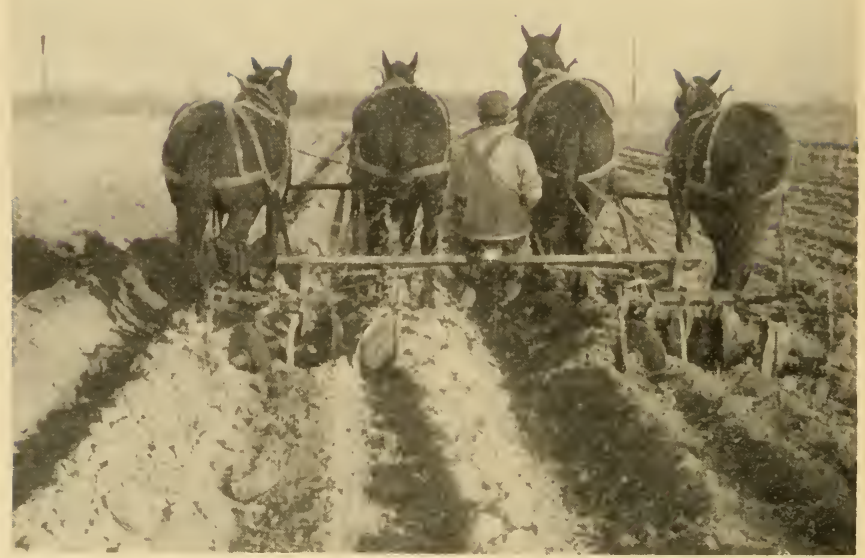

Fig. 11.-Disk lister cultivator used for filling listed furrows.

Once over with the disk cultivator is sufficient to fill the furrows, the further work necessary to prepare the seed bed being given with a common harrow.

In preparing the ground for spring wheat, the listing should be done soon after harvest and the soil worked back into the furrows again before the ground freezes. Thus it may settle and firm up during the winter, when by harrowing or shallow disking in the spring the seed bed may be put into favorable condition for planting. On land which is inclined to drift in heavy winds it is better not to level the ridges until spring as the furrowed soil will resist blowing. 


\section{ADVANTAGE OF LISTING METHOD}

In a dry climate this method of preparing the seed bed for wheat has several advantages. The cultivation of the land soon after harvest tends to conserve the moisture already in the soil, the furrows catch and store the rain and the later cultivation clears the land of weeds and volunteer wheat and leaves a mellow soil mulch to conserve the moisture which has been stored in the subsoil. The early and continuous cultivation of the soil favors the action of the soil bacteria and the development of available plant food. Also, because of the furrowed surface, a larger volume of soil is exposed to the action of bacteria.

By pursuing this method the farmer may cultivate a larger area when the soil is in good condition to cultivate, since listing is done more rapidly than plowing. Soil which is opened out in listed furrows is in the best possible condition to catch and store the rain, which as it falls soon reaches the bottom of the furrow and is rapidly absorbed directly into the subsoil without having to pass through six or eight inches of finely pulverized compact surface soil. Also the ridges may be cultivated soon after a heavy rain, thus covering the wet furrows with mellow soil and "sealing" the reservoir and preventing the escape of the stored moisture.

\section{SUMMER TILLING}

The listing method is also adapted to summer fallowing (summer tilling), the plan being to keep the surface furrowed and in a mellow condition 
to receive and store as much of the rain as possible in the fall, winter and early spring. Later in the summer, the land may be leveled, plowed and worked back into a firm, well pulverized seed bed, suitable for sowing winter wheat. In preparing a fallow for seeding spring wheat, the furrowed condition should be continued until late summer or early fall. The listing method

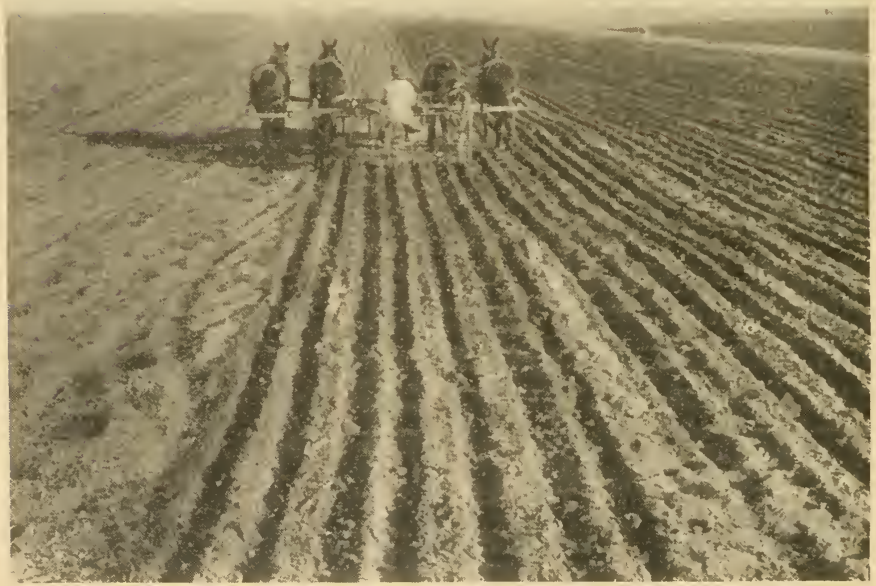

Fig. 12. - Late fall cultivation of summer fallow with twelve shovel, two-row corn cultivator to conserve moisture and prevent drifting. 
is best adapted to fairly level land but it may be used successfully on a sloping field by running the furrows across the slope. Or in the case of a field sloping in different directions, it is possible to practice "contour" listing, viz., listing around the hill, making the furrows always at right angles with the slope. Thus the rain which falls on the field will be caught in the furrows and led straight downward into the soil, rather than down the slope by surface drainage.

Experiments in preparing the seed bed for winter wheat, when wheat was grown each season, compared with late plowing, early plowing, early listing and summer fallowing, were carried on for six consecutive years (1906 to 1912) at the Hays branch experiment station in western Kansas. The crop of 1909 was entirely destroyed by hail. The average yield of five crops by the several methods is given in the following table.

\section{TABLE III}

Giving yield of wheat for five years, 1906 to 1912, and percentage of moisture in soil at seeding time for 1911 and 1912, Fort Hays branch experiment station, western Kansas.

\begin{tabular}{|c|c|c|c|c|}
\hline $\begin{array}{c}\text { Method of Prepara- } \\
\text { tion }\end{array}$ & $\begin{array}{l}\text { Yield } \\
\text { per Acre } \\
\text { Total in } \\
\text { Five } \\
\text { Years }\end{array}$ & $\begin{array}{l}\text { Average } \\
\text { Yield }\end{array}$ & $\begin{array}{c}\text { Moisture } \\
\text { in } 6 \text { Feet } \\
\text { of Soil at } \\
\text { Seeding } \\
\text { Time }\end{array}$ & $\begin{array}{l}\text { Average } \\
\text { Differ- } \\
\text { ence in } \\
\text { Yield }\end{array}$ \\
\hline ummer fallowed. & $\begin{array}{r}\text { Bushels } \\
59.9 \\
83.3 \\
104.4 \\
58.9\end{array}$ & $\begin{array}{c}\text { Bushels } \\
12.0 \\
16.7 \\
20.9 \\
11.8\end{array}$ & $\begin{array}{r}\text { Percent } \\
13.7 \\
15.6 \\
16.4 \\
19.8\end{array}$ & $\begin{array}{c}\text { Bushels } \\
-4.7^{*} \\
\text { check } \\
4.2 \\
-4.9^{*}\end{array}$ \\
\hline
\end{tabular}

${ }^{*}$ Decrease in yield. 
The land prepared by the listing method yielded 21.1 bushels more wheat per acre in the five years than the land which was plowed early and otherwise given approved treatment. Late plowing yielded 23.4 bushels less than early plowing and 44.5 bushels less than early listing. The fallowed area (cropped alternate years) gave 24.4 bushels less grain per acre in five years than continuous cropping with early plowing, and 45.5 bushels less than continuous cropping with early listing. These results are not favorable to alternate summer fallowing, and indicate that a less frequent fallow would pay better.

In Table IV are compared the yields secured at the Oklahoma experiment station by plowing at different dates in preparing the seed bed for fall wheat.

\section{TABLE IV}

Date of plowing test in preparing seed bed for wheat, Oklahoma experiment station (Bulletin No. 65).

\begin{tabular}{|c|c|c|}
\hline Preparation & Date of Plowing & Yield per Acre \\
\hline $\begin{array}{l}\text { Medium } \\
\text { Late.... }\end{array}$ & $\begin{array}{l}\text { July } 19 \\
\text { Aug. } 15 \\
\text { Sept. } 11\end{array}$ & $\begin{array}{l}\text { 31.3 bushels } \\
28.5 \text { bushels } \\
\text { 15.3 bushels }\end{array}$ \\
\hline
\end{tabular}

\section{THE SUMMER FALLOW}

In regions where the rainfall is not sufficient to produce a paying crop each year by continuous cropping, the system of summer fallowing with "summer tillage" (keeping the soil mellow and free from weeds) should be practiced every three 
or four years or in alternate years, if this is necessary, in order to store a sufficient supply of moisture in the soil to insure a profitable crop when wheat is planted. The cultivation of the fallow not only conserves the soil moisture and clears the land of weeds but also favors the development of the fertility of the soil, so that a larger amount of plant food may become available to the crop following the fallow.

\section{METHODS OF FALLOWING}

There are several methods of summer fallowing practiced in the several states; but the method which has given uniformly good results at the Montana, Nebraska and Kansas experiment stations is to plow deep, six to eight inches, rather late in the spring, and then give sufficient cultiva-

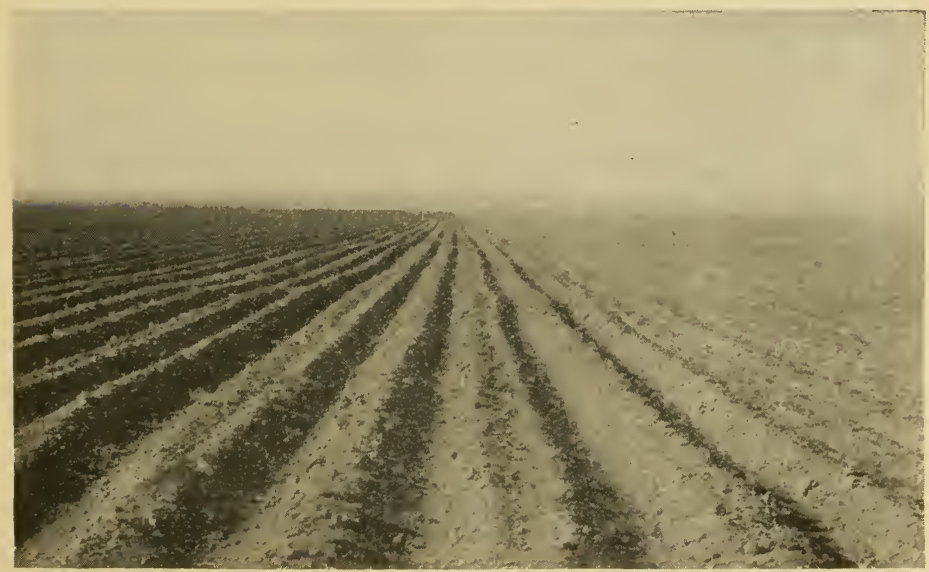

Fig. 13.--Listing the soil to prevent drifting and to conserve moisture on summer tilled land. 


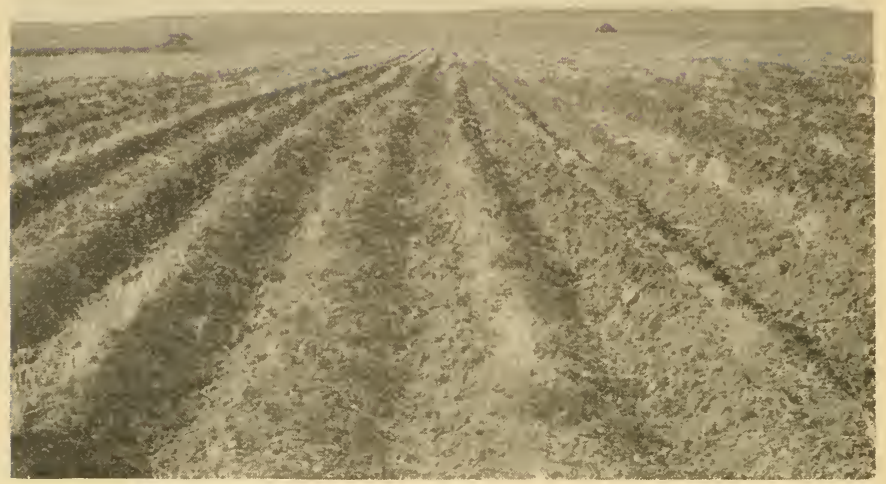

Fig. 14.- Soil that has been listed in the best possible condition to eatch the rainfall.

tion thereafter to maintain a soil mulch and destroy weeds. Such treatment puts the soil in ideal condition for seeding in the fall or spring, but the continuous cultivation leaves the surface soil finely pulverized and smooth, which favors soil washing with heavy rains and soil drifting in strong winds. Some practice plowing twice, rather shallow in the spring and deeper the second time about midsummer, giving surface cultivation after the second plowing sufficient to prepare a good seed bed.

Summer tillage may exhaust the plant food of the soil faster than continuous cropping, since 
there is apt to be a waste of the soluble plant food elements by wind and drainage. On account of these facts summer tillage should not be generally practiced except in regions of very light rainfall and in the western plains region, which is subject to very strong winds, only in the heavier soils or more protected locations.

The listing method of summer fallowing has not yet been tested in comparative trials at the experiment stations, but wherever there is danger of damage by soil drifting, the listing method, as described above, should be preferred to plowing and harrowing.

\section{TO PREVENT SOIL DRIFTING}

How to prevent soil drifting has become a very serious problem to the western farmer during the last few years. The breaking of the prairie sod, the pulverizing of the soil by tillage, the dry seasons, and continuous cropping have made the surface soil finer and looser, which conditions favor soil blowing in the heavy winds which are characteristic of the western plains.

The rotation of crops and seeding a part of the land again to grass, together with the planting of shelter belts and wind breaks, will be some of the permanent means employed to solve this problem. Meanwhile it is possible to temporarily prevent soil drifting by practicing proper culture methods and by protecting the surface with a dressing of straw or manure pressed into the soil with a packer or a disk harrow. 


\section{SPREADING STRAW AND PACKING}

The writer prevented the soil from blowing on an eighty acre wheat field at the Fort Hays experiment station in western Kansas in the spring of 1911, by spreading straw over the field during the winter and packing it into the soil early in the spring with a subsurface packer. The packer pressed the straw into the ground causing it to stand partly on end. This kept the straw from blowing away and served as a protection to the ground, which entirely prevented the soil from drifting on this field in the very severe wind storm of March 26 of that year, notwithstanding the fact that this field was not well covered by the growing wheat which had made little growth in the fall and was therefore inclined to blow. Other fields on the experiment station farm which were not protected with straw did blow badly.

During the storm referred to, the effect of the straw as a barrier to stop the drifting soil was shown in another field of 160 acres of wheat. In this field, straw had been spread in a narrow strip five or six rods wide, extending east and west across the field, and had been packed into the soil with the subsurface packer. The north side of the field started to blow and the loose soil was swept south, taking nearly the whole field north of the straw-covered area, but here the drifting soil lodged in the straw and did little harm to the wheat south of this barrier. The subsurface packing alone without the dressing of straw crosswise of the drill rows early in the spring also had 


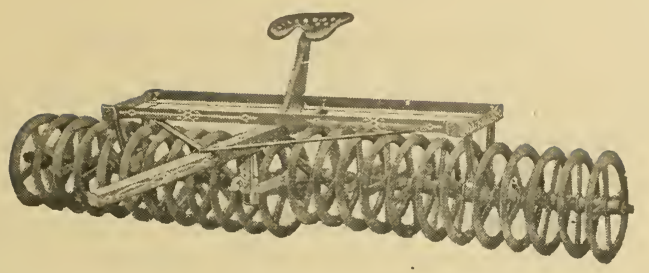

Fig. 15. - The Dunham sub-surface packer.

a beneficial effect and aided in preventing soil drifting.

\section{SHALLOW FURROW CULTIVATION}

On the same farm in the spring of 1912, I stopped the soil from drifting on a newly seeded alfalfa field 120 acres in area, by cultivating the drifting area with a twelve shovel two-row corn cultivator, cultivating across the wind, beginning on the side towards the wind. The drifting was stopped early in the day, with a loss of about seven acres of alfalfa, whereas if nothing had been done to check it, the drifting would have extended over the larger part of the field during the day. The middle shovel of each gang of three in the cultivator was removed. This left the soil in furrows and ridges.

By the same method I have protected the surface of a bare summer fallow by running shallow furrows east and west across the field. One hundred-eighty acres cultivated in this way late in the fall of 1911 did not drift during the winter and was put into good condition for seeding alfalfa the next spring by a single cross harrowing. The shallow furrows did not loosen the seed bed too deeply. 


\section{DEEP FURROWS WITH LISTER}

The best culture method to prevent soil drifting on open, bare fields is to list the soil into deep furrows and high ridges, preferably running east and west, with the lister or double mold-board plow. This condition offers almost complete protection from soil drifting. The soil should be listed when it is not too dry and loose. Even when the soil is drifting on a field, it may be stopped by listing, unless it is very loose and sandy, by starting the lister on the side towards the wind. In the fall of 1911, nearly 600 acres were listed on the Hays experiment station farm, including all corn and kafir stubble fields and all land which was to be summer fallowed or planted to intertilled crops in 1911. The results were so favorable that the same plan was continued in the fall of 1912 .

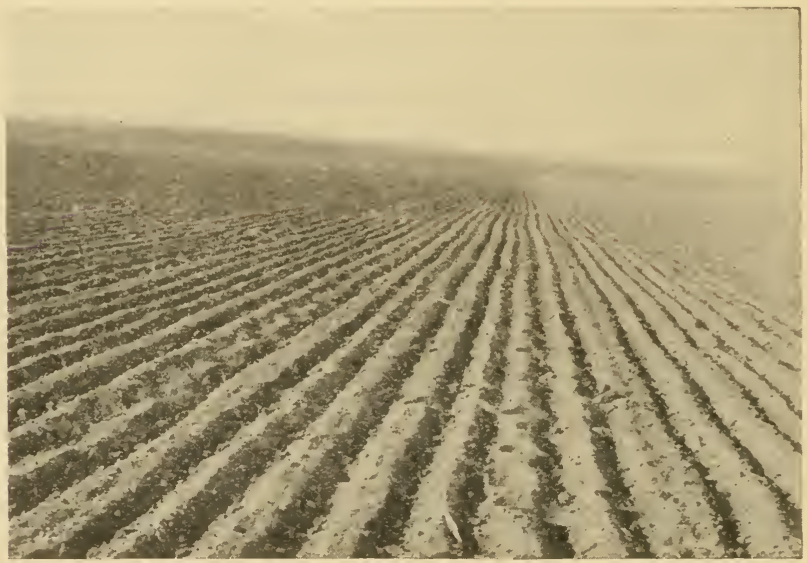

Fig. 16.-Shallow furrows do not loosen the seed-bed too deeply. 


\section{Chapter V}

\section{WHEAT SEEDING AND CULTIVATION}

Spring wheat should be sown as early in the spring as the soil can be put into favorable seed bed condition. It is preferable to risk damage by spring frosts in order to start the wheat early and thus hasten its maturing, in order that the crop may escape rust and unfavorable weather conditions which are likely to damage the grain near harvest time.

It is difficult to name any best date for sowing fall wheat, because this will vary greatly for different sections of the country, and in different seasons even in the same locality. In the more northern areas of the winter wheat belt early seeding is usually desirable in order that the wheat may make a good start and a good cover in the fall, to afford winter protection. In the warmer climates rather late seeding is often preferred because a too rank growth from early seeding is more apt to smother during the winter. Also the early seedings are liable to attack by the Hessian fly which appears early in the fall and lays its eggs on the early sown wheat. When it is necessary to sow rather late, special care should be taken to have the seed bed in ideal condition to start the wheat quickly, since young, weak plants are more likely to winter kill, and the lack of cover exposes the crop to damage by wind and drifting soil. 


\section{METHODS OF SEEDING}

When possible always sow wheat with a good drill. Drilling requires less seed than broadcasting because the seeds are more evenly distributed and more evenly covered, thus giving a more uniform germination. Drilled wheat is less likely to winter-kill because of the stronger plants, and there is a slight protection afforded by the shallow furrows. Many comparative tests at several experiment stations have given increased yields from drilling from two to ten bushels per acre.

In the spring wheat states, wheat follows corn with good results when the seed bed may be well and cheaply prepared simply by disking and harrowing. Winter wheat may follow early potatoes, or other early maturing intertilled crops which have been well cultivated, without plowing. Also, it is common practice in Kansas and states farther south to drill wheat with a one-horse drill in standing corn.

When wheat follows wheat or other small grain, while the general practice is to plow or list the stubble land soon after harvest and prepare the seed bed by giving the necessary surface cultivation, yet in parts of western Kansas and Nebraska many farmers disk in preparing the wheat seed bed without plowing, and much wheat is simply "stubbled in," or drilled in the stubble without any cultivation previous to sowing. This is a careless method, and yet where the soil drifts badly it seems advisable to practice it sometimes and not plow every year. 


\section{GRAIN DRILLS}

For general use the writer prefers a good single disk drill. They are the best trash riders, but in well prepared soil the double disk drill and shoe drill may do the better work, being more readily adjusted to plant the seed at a uniform depth.

The press drill is often preferred for use in the lighter soils and drier climate. The better the preparation of the seed bed and the greater the storage of moisture in the subsoil, the less necessary the press wheels, and if the soil is wet and sticky and apt to roll on the wheels or crust, better work may be done with chain coverers than with the press wheels. It is an advantage to have the drill equipped with both chains and press wheels and use whichever will give the best results.

There is an unquestionable advantage in planting corn in deep listed furrows in a dry climate, and there may be a similar advantage in planting wheat in shallow listed furrows, a little deeper than the furrows made by the ordinary drill. Listing drills are now being manufactured and are used to a limited extent. The writer is not familiar with the results of their use but would recommend them for trial. In dry farming areas which are not likely to receive heavy rains after sowing, and where the soil is light and inclined to blow, seeding with a listing drill should give an advantage over the ordinary method.

\section{THICKNESS OF SEEDING}

It is usual to sow wheat in drills six inches apart. However in the dry climates a greater 
space between drills, seven to eight inches, andi even wider space is often preferred. The practice of planting wheat in rows in semi-arid areas, eighteen to twenty-four inches apart, and cultivating the crop has not given profitable results. There is a disadvantage in planting the drills too far apart because the wide spaces allow the growth of weeds and the wheat does not make so good a covering in its early growth, favoring soil drifting in windy climates. The proper thickness of stand should be secured by planting the seed thinner in the drill rows rather than to make the space between drills wider than six or seven inches. Comparative tests have usually favored planting in the closer drills. The amount of seed required to sow an acre varies from two to three pecks in the dry farming area to six to eight pecks in the more humid climates.

\section{DEPTH OF SEEDING}

Wheat should not be covered too deeply. A usual depth of drilling is two to three inches. To

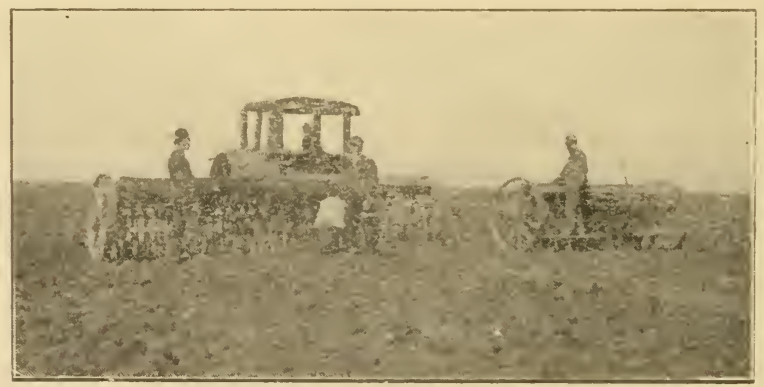

Fig. 17.-Drilling in wheat with a tractor. 
secure ideal conditions for germination the seed should be deposited in the bottom of the drill furrow or against the firm soil which will supply moisture to swell and sprout the seed and give a favorable environment for the young roots. Thus the surface of the seed bed should not be loosened too deeply or too near seeding time.

If the surface is loose and dry and there is moisture beneath, it may be better to deposit the seed against the firm soil even at a depth of four or five inches rather than to deposit it near the surface of the loose, ashy bed where it will be entirely dependent upon rain to sprout and grow. In a wet season shallow seeding in a deep, loose seed bed may give good results, but it is better to prepare a proper seed bed.

\section{WINTER KILLING}

Winter killing of wheat occurs frequently throughout the northern and middle portions of the winter wheat belt, and is often a source of great loss and inconvenience. Wheat winter kills in several ways:

1. It may not be hardy enough to withstand the extreme cold of severe winter weather.

2. Late sown wheat or weak plants may die for lack of moisture in a dry, open winter. Even a good stand of wheat may be destroyed by such unfavorable conditions, especially if planted in a loose seed bed which was not well stored with moisture.

3. The grain may smother under a covering of ice or closely packed, icy snow. A heavy fall 
growth from early seeding is more apt to smother than later sown wheat or wheat which has been fall pastured.

4. The most common kind of winter killing is caused by soil heaving, due to the alternate freezing and thawing of very wet soils, which gradually lifts the plants, exposes the roots and finally raising the plants entirely clear of the soil, breaks the roots completely destroying the crop. Such winter killing is more likely to occur on poorly drained, heavy, sticky soils that remain wet at the surface than on soils of a more sandy or loamy character. Soil heaving is most likely to occur late in the winter or early in the spring, but it may occur earlier in the winter, during a period of open weather when the surface soil is wet.

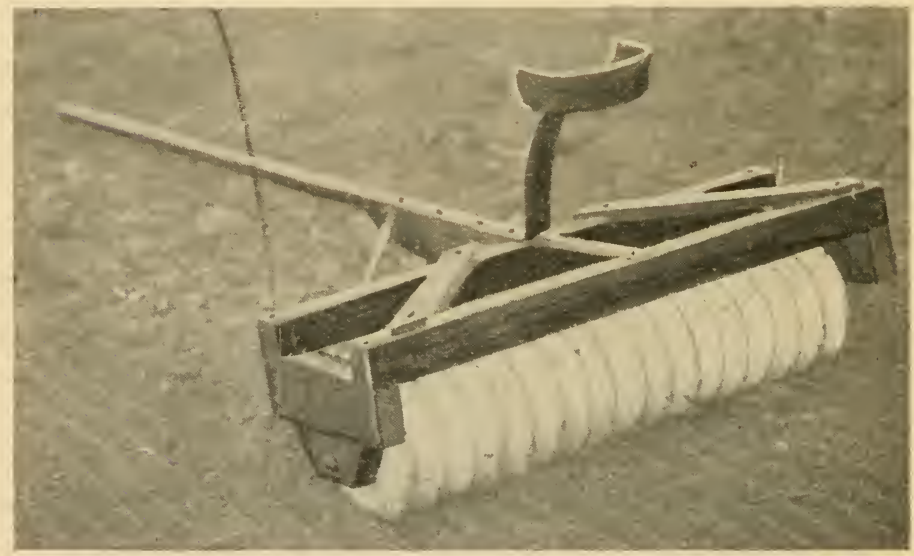

Fig. 18. - A successful cement, home-made roller. 


\section{MEASURES TO PREVENT WINTER KILLING}

Very little can be done to prevent winter killing when the unfavorable conditions are present, but there is more or less tendency to winter killing that may be, in a measure, prevented by making the growing conditions for the wheat as favorable as possible. Naturally wet land should be drained. A well pulverized, well settled seed bed may not heave so much as a loose seed bed and the wheat will not "freeze out" or dry out so quickly in a firm soil, hence careful preparation of the seed bed is a partial preventive. Other preventive measures are medium sowing (not too late or too early), pasturing a rank fall growth, and providing wind breaks or shelter belts to break the wind and catch the snow. Wheat seldom winter kills if it has a good covering of snow all winter. Rolling the wheat early in the spring to firm the soil about the roots will often give much benefit if the heaving has not progressed too far.

Some varieties of winter wheat are much hardier than others to resist winter killing, as shown by the trials at our state experiment stations, and only such should be sown, Avoid bringing seed wheat from the south for seeding in northern sections, since it will usually prove less hardy than northern grown seed.

\section{CULTIVATION AFTER SEEDING}

The proper preparation of the seed bed is a much more important factor in the growing of small grains than the cultivation after seeding. 
It is seldom necessary to cultivate the wheat seed bed after seeding. The necessary cultivation to cover the seed should be given the broadcasted field. In the growing of wheat the preparation of a favorable seed bed should leave the soil mellow at the surface. There are usually no heavy showers in the fall after the wheat is sown or early in the spring, the wheat grows rapidly, and by stooling soon covers the ground and protects the soil from beating rains. Thus wheat needs less cultivation after planting to maintain the soil mulch than is required by corn or other intertilled crops.

After the wheat is up several inches and beginning to stool it may sometimes be harrowed with a light harrow or "weeder" to break a crust

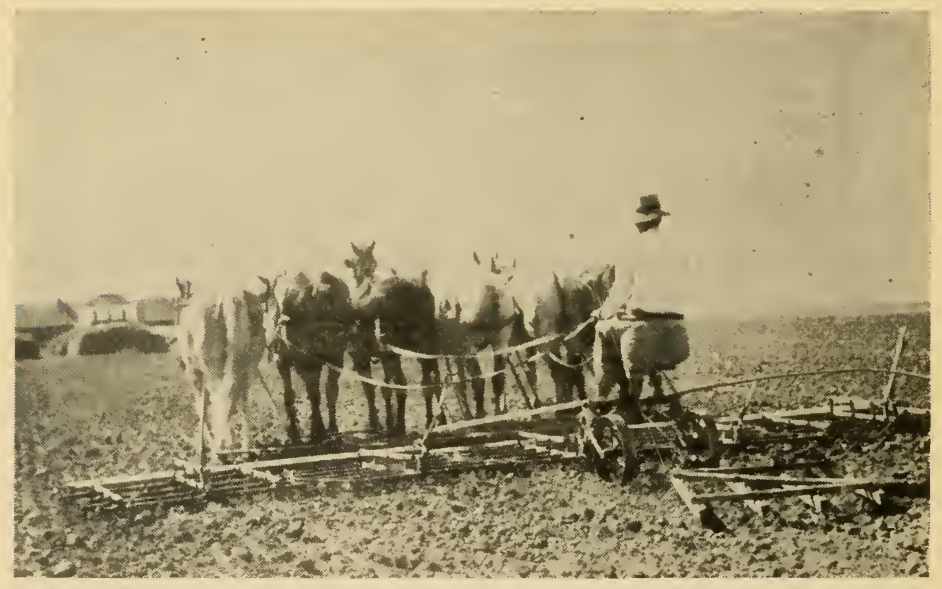

Fig. 19.-With a gang of harrows one man can cover eighty acres a.day. 
formed by heavy rains, but care should be taken not to loosen the soil too deeply so as to disturb or loosen the roots of the plants. The harrowing of young grain by covering the slender blades, may injure the stand.

The results of experiment station trials in harrowing wheat have not always been favorable. Winter wheat may often be rolled in the spring with advantage when there is much heaving of soil, in order to pack the soil about the roots. Rolling winter wheat in the spring at the Nebraska experiment station (Lincoln) increased the yield of grain five bushels per acre as an average for five years. In a windy climate it is dangerous to roll wheat as the smooth, pulverized surface soil left by rolling will drift, and destroy the crop and waste the soil. The writer has used the subsurface packer in place of the roller at the Fort Hays experiment station in Kansas with good results. The subsurface packer presses the soil about the wheat roots and leaves the surface slightly furrowed, which tends to resist soil drifting.

\section{PASTURING WHEAT}

It is a common practice to pasture winter wheat, and when done judiciously there may be no reduction in yield. In fact, aside from the pasturage value which is estimated at from fifty cents to two dollars per acre, there may result an actual benefit to the crop from pasturing a rank growth of wheat on fertile soil. The grazing reduces the straw growth and may prevent winter smothering as well as lodging and blighting. The firming of 


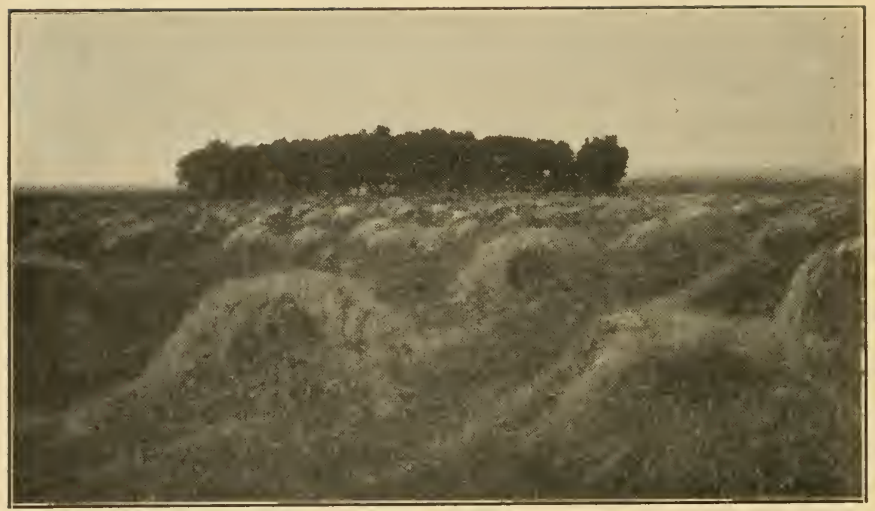

Fig. 20.-Summer-tilled wheat field, North Platte, Nebr. substation. Yield, sixty-seven bushels per acre.

the soil by the tramping of livestock may also prove an advantage on light land, or on a seed bed which was not well settled before seeding. A weak growth of wheat should not usually be pastured since the grazing will tend to reduce the vitality of the grain still more and result in a decreased yield.

Wheat may be pastured in the fall and early spring when the soil is not too wet or too dry. Very dry soil becomes pulverized and dusty by the tramping of stock, and soil drifting results. The tramping of very wet soil causes it to " poach" and puddle and the stand of wheat is likely to be injured. Too late pasturing in the spring retards the growth of the wheat and reduces the yield. At the Kansas experiment station, pasturing wheat on land of average fertility decreased the 
yield three bushels per acre as an average for several trials.

\section{SPRING MOWING}

When it cannot be pastured, mowing a very rank growth of wheat on fertile soil, early in the spring before it begins to shoot, will reduce the foliage growth and may prevent lodging and result in an increased yield. The writer has practiced this method with good results at the Kansas experiment station. If the growth is not too heavy, it may be left on the ground or the green wheat gathered for ensilage. 


\section{Chapter VI \\ HARVEST AND YIELD}

\section{THE AVERAGE YIELD}

Because of the relatively high price of the grain and the relatively low cost of production a good field of wheat is one of the best paying of farm crops. The yields are sometimes very large. The writer has produced a yield of sixty bushels of Turkey wheat per acre at the Kansas experiment station, not only in small plots but in a large field. Even larger yields have been reported in Kansas and in the Palouse country in Oregon, where yields of seventy bushels per acre have been secured. Yet in spite of the great producing capacity of wheat under favorable conditions, the average yield in the United States is less than fourteen bushels per acre. Compare this with the average yields of wheat for the last decade in several European countries-Germany twentynine bushels, Great Britain thirty-three bushels and Denmark forty bushels per acre, and we will see that the yields in the United States may be and should be greatly increased.

\section{CAUSE OF LOW YIELDS}

The low average yield of wheat in the United States is due to two primary causes-poor farming and damage to the crops by the elements. Much wheat is very carelessly planted. The farmer is continuously up against the problems of a decreasing soil fertility and a consequently decreasing 


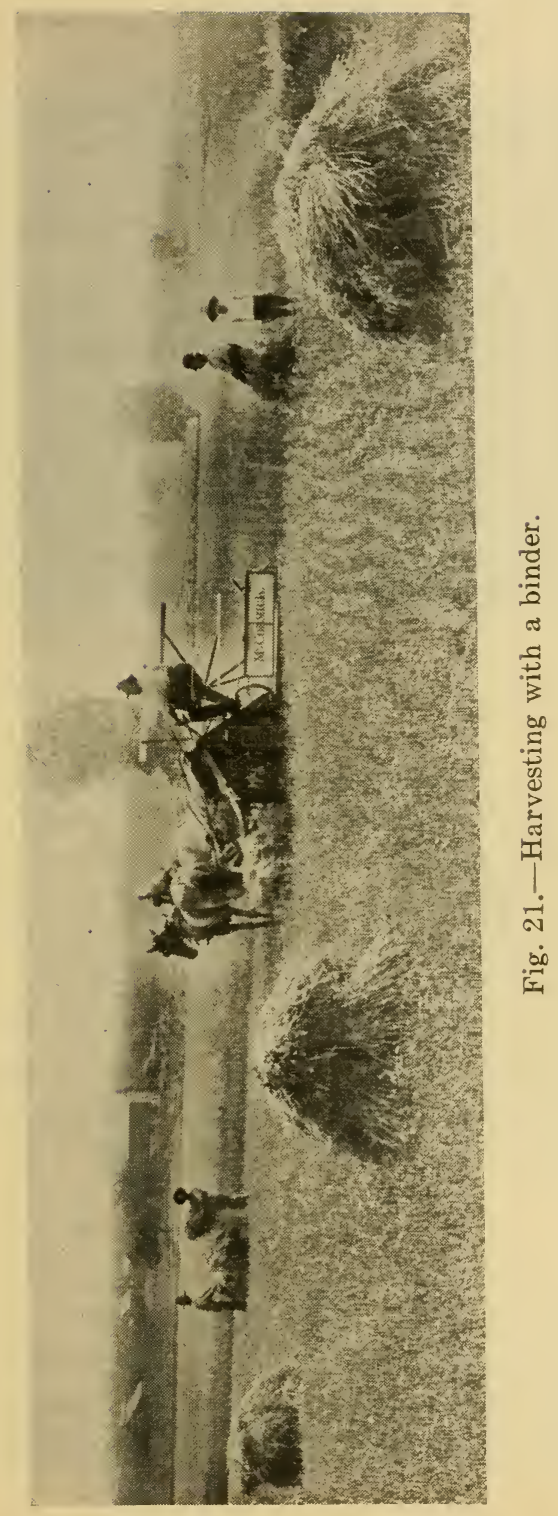


productivity. The wheat crop is very susceptible to injury from unfavorable weather conditions at almost every stage in its growth. Dry weather at seeding time may cause a thin stand, or the grain may blow out or winter kill or be injured by drouth and hot winds almost up to the maturity stage; or it may be damaged by hail or lodged by storms and wind either before or after maturing, and even after harvesting it is liable to be damaged by wetting in the shock, causing bleaching and sprouting, thus reducing the yield and injuring the quality of the grain.

\section{DATE AND METHOD OF HARVESTING}

The wheat harvest of the United States begins in Texas in May and ends in North Dakota in August. In California the harvest begins about June first and continues nearly two months. East of the great plains, wheat is cut as soon as it is ripe or a little before, the harvest extending usually over a period of only a week or two weeks on a single farm. The grain is bound into bundles with a self binder, and placed in small shocks in the field; and later when it is dry enough it is hauled directly to the thresher, or more often put into stacks or barns and threshed later.

\section{THE HEADER}

In the western plains the common method of harvesting is with the header. The wheat is allowed to stand until fully ripe, when the heading begins and the headed grain is loaded loosely into barges and hauled directly to the stacks, 


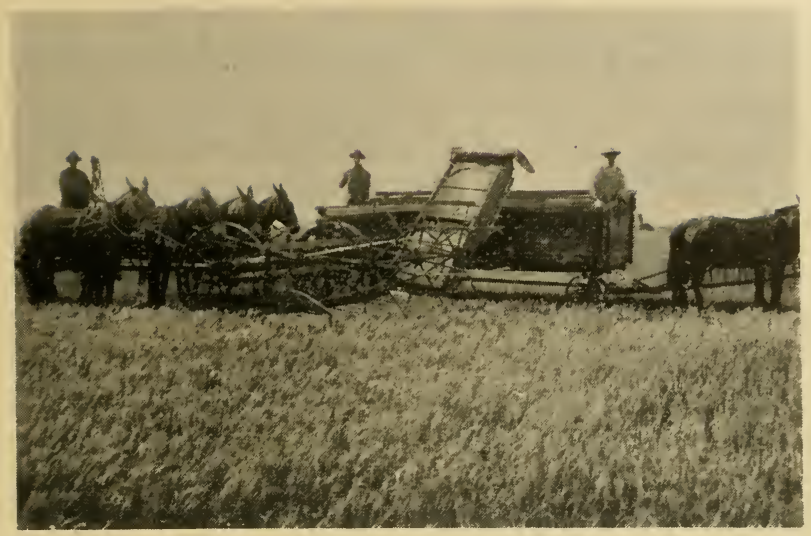

Fig. 22.-Harvesting wheat with a header in western Kansas.

which are arranged in regular groups or "settings" of two to four stacks, usually ten acres to a "setting." In the western states the harvest may continue for a month or six weeks on a single farm. This method of harvesting is rapid and economical and is well adapted to a dry climate, but often the over-ripe wheat shatters and is damaged by storms and deteriorates in quality. In the eastern part of the dry farming belt the binder and the header are often both used on the same farm, thus making it possible to harvest more of the grain in prime condition.

\section{THE COMBINE}

On the Pacific coast where there is no danger from rains, the harvest lasts for several weeks or months, and the wheat does not usually deter- 
iorate in quality in the field. It is sometimes damaged by sand storms. The club or square head wheat is the type generally grown, and its short straw and tight glumes prevent lodging and shattering. On the great wheat fields of California and Oregon the "combine" is used, which harvests and threshes the wheat at a single operation, the grain being sacked and left in long trains in the field or later placed in large piles, from which it is hauled and loaded directly onto the cars for shipping. The relative harvesting capacity of the different machines and methods may be compared as follows:

Machine

Width of Swath Harvesting Capacity in Feet per Day in Acres

Binder.

5 to 8

Header.

8 to 14

Horse combine. . 16 to 20

10 to 20

Steam combine. 24 to 42

20 to 30

25 to 45

75 to 125

The average price of a steam "combine" outfit is $\$ 7,500.00$. They are used almost exclusively on the Pacific coast, and only on the larger farms containing from 3,000 to 20,000 acres of land. The horse "combine" is most advantageously used on the smaller farms having less than 3,000 acres.

\section{BEST STATE OF MATURITY TO HARVEST}

Wheat makes the largest yield and best quality of grain if harvested with the binder when it is just about fully ripe when the straw has mostly turned yellow and the grains are quite hard or in the hard dough stage. Wheat cut immature 
is apt to become shrunken, making a decreased yield and lighter weight per bushel, and it is less strong in vitality than plump wheat; but by careful grading it will usually make good seed, and if not too light, may make good flour. It is a good practice in humid regions to begin harvesting before the grain is fully ripe because as soon as the wheat is over-ripe it may be injured by storms and by rain which may lodge the grain or bleach it and cause it to deteriorate in quality and vitality, and the yield is likely to be reduced by shattering. In cutting with the header it is necessary to wait until the grain is dry enough to stack without danger of heating and spoiling. The binder may often be started a week or ten days before the header.

\section{SHOCKING}

Perhaps more wheat is injured in quality after harvest by unfavorable weather and careless handling than from any other cause. Some farmers are not only careless but absolutely neglectful in this respect. If the wheat is cut a little green, prompt shocking facilitates the completion of the ripening process, favoring the transfer of the material from the straw to the grain, which prevents shrinkage; also the sheaves may be set up in better shocks if the straw is not allowed to become too dry and fluffy and brittle.

Whether to cap shocks or leave them uncapped is a question. Unless wheat is well set up and the shocks carefully capped, the caps are apt to blow off and the grain will then become more 
exposed than if the bundles were originally set in open shocks. The writer prefers to carefully shock and cap in humid climates rather than to set in long shocks or round shocks without caps. It may be necessary to go over the field after a wind storm and replace the caps that have blown off.

\section{KINDS OF SHOCKS}

Long shocks are made by placing pairs of sheaves in a row, about twelve bundles in a shock, setting them down firmly and not too sloping, a pair at a time, and bracing the bundles against each other. Place the pairs alternating at each end to keep the shock plumb and regular. The outer pairs of bundles should slope slightly towards the inner pairs in order to brace the shock. A round shock with caps should contain from twelve to sixteen bundles. The writer prefers rather large round shocks if the grain is not too green, as they stand better. In building a round shock of sixteen bundles, place four pairs in a row, then place three bundles on each side and cap with two bundles. After the tops of the sheaves have been drawn somewhat together lay one bundle on the top of the shock at right angles to the prevailing winds, then break the second cap sheaf at the band, and spreading the ends fan-shape lay it cross-wise of the first cap with the tops towards the prevailing wind.

Both for efficiency and economy of time two bundles should be handled at once. Shocking is a man's job. There is a knack about it that may 
be easily learned by practice, but the average hired harvest hand is usually a poor shocker. In windy, dry climates as in our western plains, where storms may be severe but with no great amount of rain, it may be advisable to build a round shock without caps something after the manner of a miniature stack. Lay one bundle on the ground and break the top back to keep the heads off the ground; set two others over this one at right angles, with heads crossing. Now fill in the angles with other bundles thus thatching the shock and bringing the top of the last bundle over the heads of the others until nine to thirteen bundles have been placed in the shock. The bundles should all stand quite sloping. Such a shock will shed rain well and will not blow over.

\section{STACKING}

In parts of our wheat growing areas, bundle stacking is almost a lost art because of the present day practice of threshing out of the shock. In the writer's judgment, this is a mistake. There may not be any economy in stacking if the threshing can be done early and as soon as the grain is dry enough, but this is not usually the case. Many farmers are obliged to leave their grain in the field for several weeks or months, until the thresher can make the rounds of several other farms, and if unfavorable weather intervenes the grain may be badly damaged; while, if such grain could be stacked in well made stacks just when it is in prime condition, it would mean a great saving of grain and the extra labor would be 
a profitable investment for the farmer. On the other hand, grain that is carelessly stacked may be badly damaged by heavy rains wetting the stacks; but if the stacks are well and properly made such damage should not occur.

\section{HOW TO BEGIN A STACK}

In starting a bundle stack, whether round or elongated, the bundles should be set up in the form of a large shock beginning at the middle of the stack and setting the bundles in regular order until the confines of the stack are reached, about ten feet in diameter for a round stack and ten feet wide for a rick. Then beginning at the edge, lay a double tier of bundles around the whole stack, the butts of the first row reaching the ground, with the butts of the second row just flush with the butts of the first row. Now lay a single row with the butts reaching a little past the bands of the first row, and continue this method, laying row after row around the stack until the center is reached. The rows of bundles may be lapped a little more toward the middle of the stack in order to keep the middle full, always having a good slope towards the edge of the stack. Starting again at the edge of the stack lay the first row of bundles with the butts flush with the original first row or extending a trifle, and then work toward the middle of the stack as before.

\section{HOW TO BUILD AND COMPLETE A STACK}

At the third round, extend the butts of the 
outside row a few inches beyond the butts of the row beneath, and continue thus as succeeding tiers and rows are placed, "laying out the stack," always keeping the middle full, until the stack is seven or eight feet high. This forms the bulge. Now begin to draw in the outside rows a few inches at each round, thus finally bringing the stack to a narrow top made by the lapping of the last rows of bundles which should be tied down by driving sharpened sticks four to five feet into the top of the stack. The bulge should extend two to three feet beyond the base, which will make a stack with a ten foot base, fourteen to sixteen feet wide at the bulge. Do not tramp the outside rows of bundles. Pitch from both sides of the stack if possible. Each successive tier of bundles should thatch the preceding one, much the same as the shingles on a roof. Take considerable care as regards thatching above the bulge. By proper stacking, the grain below the bulge should be entirely protected from wetting.

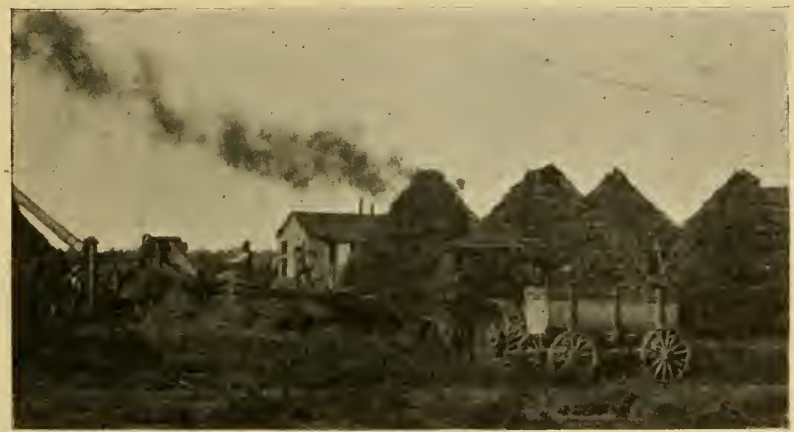

Fig. 24.-A good job of stacking. 


\section{THE SECRET OF GOOD STACKING}

The secret of good stacking is to keep the middle full so that when the stack settles the bundles will slope towards the butts and towards the outside of the stack. Also the stack must be built plumb and regular. It is a job which requires some practice and considerable care, and a good stacker may well command an extra wage for such work.

In stacking loose grain from the header, the same principle holds that the middle of the stack must be kept full and well tramped. The sides of the stack should be raked to remove the loose straw. and hangers should be placed as soon as the stack is completed to prevent the wind blowing off the top which is likely to occur in the first storm unless the top is tied down.

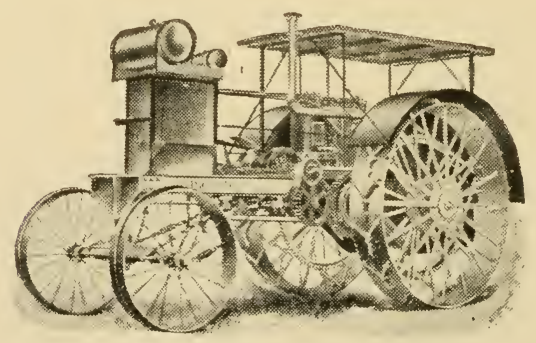




\section{Chapter VII}

\section{THRESHING AND MARKETING}

Threshing directly from the shock is perhaps the best and most economical method, if the threshing can be done early, as soon as the grain is dry and in good condition. Grain threshed from the shock will go through the sweat in the bin, but unless threshed damp it will not heat enough to injure the quality of the grain; in fact, a little heating may be desirable as it will give the grain a darker, richer color. When the grain is stacked it should be allowed to go through the sweat before threshing. If threshed and put into a dry bin it may not sweat, since the sweating process requires that grain contain some excess moisture. Sweating may not be necessary for producing a good quality of grain, but it is desirable that wheat contain enough moisture when it is stacked or threshed to cause it to sweat; otherwise it will handle badly, shattering during the stacking or cracking during the threshing. Do not stack or thresh when the grain is too damp, since such grain may heat too much or become stack-burned or bin-burned and thus injured in quality and value, while its vitality for seed may be entirely destroyed. Also there may be considerable loss in threshing too damp or too tough grain, since all the grain may not be removed from the straw.

\section{MARKETING}

Much grain is now hauled directly to the elevator from the threshing machine and sold or 
stored for future sale. If the price is relatively high at threshing time it is usually advisable to sell at once. Often the price is high when threshing first begins but decreases as the supply of grain increases. The present tendency of rushing the grain to market at threshing time often results in glutting the market and lowering the price below normal; and also the railroads and elevators are unable to handle the large quantities of grain properly. It would be better if more grain were stored in good bins on the farms and hauled to the market at an opportune time. This plan would tend to keep the market more steady and allow for the grain to be handled in better condition and more economically.

\section{SHRINKAGE AND STORAGE}

The shrinkage of dry wheat, as threshed and placed in the bin, is very small and will seldom amount to $2 \%$. One percent is an average shrinkage for six months, and after the first loss of excess moisture, the grain should not decrease in weight even by longer storing, except as it may be injured by insect or animal pests. In the warmer climates, grain stored for several months is likely to be attacked by weevil and often severely damaged. Hence as a rule it is not advisable to hold wheat over during the summer in Kansas and states farther south, unless due precaution is taken to prevent weevil damage.

The farmer should take into consideration the cost of storage in making his decision whether to sell or not at threshing time. This cost, including 


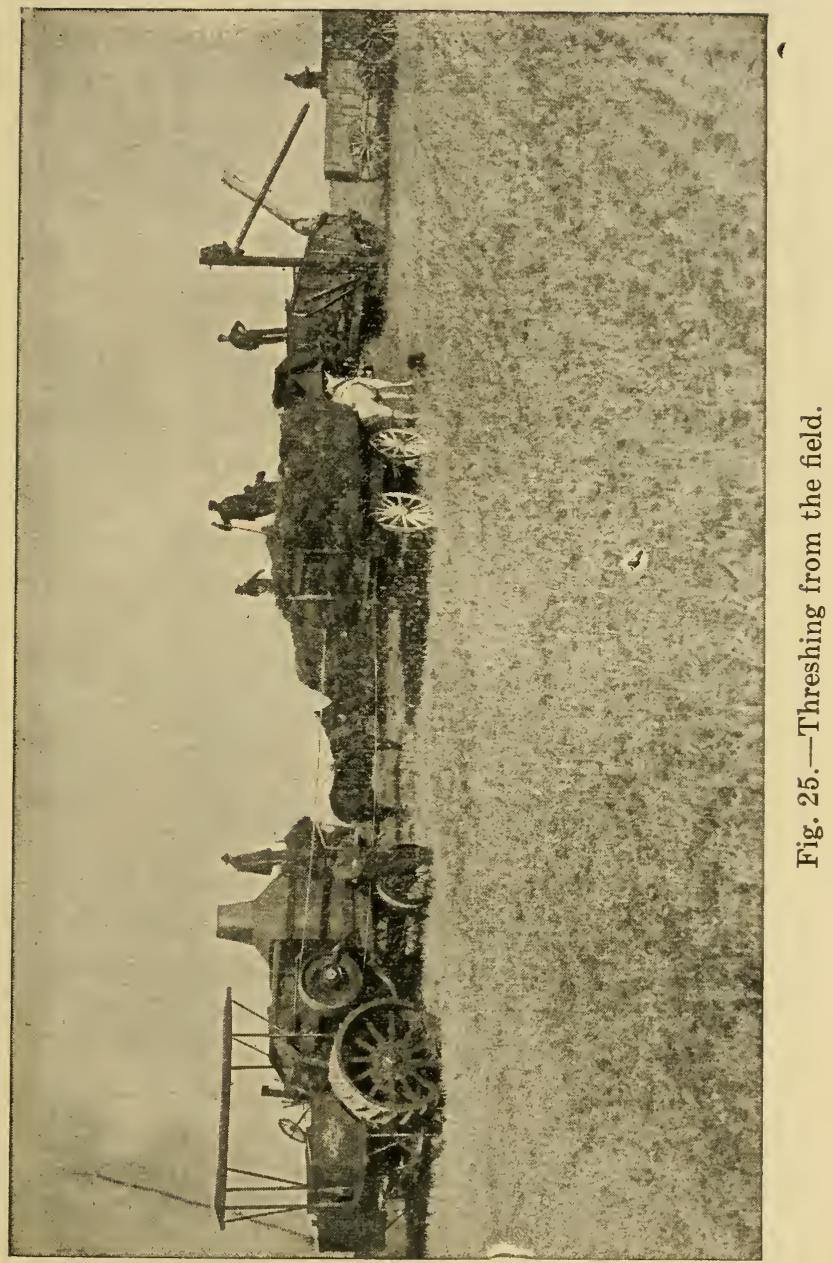


the storage charges, the natural shrinkage in weight, the insurance against loss by fire and cyclone, the interest on the money represented by the value of the wheat and the extra cost of handling the grain, may amount to from five to ten cents per bushel depending on the length of time of storage. Thus eighty to eighty-five cents per bushel at threshing time may be better than ninety cents six months later.

\section{THE PRICE OF WHEAT}

The market price of wheat is normally determined by the world's conditions of supply and demand. The United States produces more wheat than is required for local consumption, therefore the price is fixed by the country which buys the export, but such price should under normal conditions be higher than the surplus producing country could fix for itself. Hence the export price is a benefit to the wheat grower.

\section{TRICKS OF THE TRADE}

It is true that with a large, visible supply of wheat in a certain section the tendency is to depress the local price at threshing time when the bulk of the crop is sold, but this is a "trick of the trade" on the part of the buyers, due in part to the congested condition and the impression which the farmer receives that the supply is greater than the demand. The true market price of wheat is always established by the world's supply and not by the crop of any one state or locality. 
Under the present conditions of trade by individuals or corporations, the local price of wheat depends largely on competition. For example, two cents less per bushel was paid for wheat at a non-competitive point in North Dakota than at competitive points only six miles distant. When the local elevator systems combine, the only effective remedy is for the farmers to combine and start independent elevators, and secure the aid of the law if necessary to get their wheat shipped to the primary markets. The matter of marketing and securing the highest market price is an important part of the wheat raising business, and will receive much more attention and consideration in the future than it has in the past.

\section{COMMERCIAL GRADING OF WHEAT}

The value of wheat varies with its quality and with the purpose for which it is to be used. The principal characteristics which aid in fixing the grade are weight per bushel, plumpness, soundness, color, and freedom from smut, foreign matter and from mixture with a different type of wheat. Since gradations are continuous, it is difficult to draw the line, hence grading recuirements are not very definite and are often largely a matter of judgment by the grain inspector. The commercial classes vary somewhat in the different markets. The general classes on the Chicago market are: White Winter Wheat, Red Winter Wheat, Hard Winter Wheat, Northern Spring Wheat, Spring Wheat, White Spring Wheat and Colorado Wheat. Each class has from two to 
four regular grades, and wheat may be of such poor quality as to be graded "rejected" or "no grade."

\section{INSPECTION AND SUPERVISION}

The rules for grading grain are fixed by boards of grain inspectors in the several states where the great markets are located. These rules are published and may be secured from the chairmen of said boards, or from almost any grain dealer. In all the great markets there is a rigid system of grain inspection and grain grading under state supervision and control which greatly facilitates the movement of wheat and reduces fraud and unfairness in the grain trade. State weighing departments have been established at the great terminals in several states, by which all the wheat is now officially weighed, and the cheating by false weighing which was formerly notorious has been practically done away with.

\section{LOCAL GRAIN INSPECTION}

There is much less organization and control of the handling of grain at the local elevators than at the terminals. The correctness of the weighing and the grading, and the fairness of the price of wheat at the local elevator depend largely on local competition and on the honesty of the grain dealer. As a rule; the local buyer is honest in the weighing. Fraudulent weighing is very much condemned by all grain dealers associations, and usually competition compels the dealer to pay all the market will allow. 
The local dealer often gives too little consideration to the actual quality of wheat in fixing the local market price. He learns about what the general run of the wheat bought at his elevator will grade, and he then pays about the same price to each farmer, even though the wheat may - actually vary considerably in quality and grade. The writer has stood at a grain elevator in a western Kansas town and observed the delivery of wheat which in his judgment, should have been given three different grades, yet the grain was all graded No. 2 and sold at the same price. This is not only unfair to the farmer selling the better grade of wheat but it encourages carelessness and neglect on the part of the producers in keeping their grain pure and of high quality. The grain dealer should make it to the advantage of the farmer to sell a pure type of wheat of high grade by paying a higher price for such grain, and he should advertise the fact.

\section{CO-OPERATION THE SOLUTION OF THE PROBLEM}

The establishment of co-operative grain elevators by the farmers has progressed rapidly in the last ten years, and is having a salutary effect in maintaining more uniform prices to the producers, but such co-operation considers one side of the problem only - the producer's side. It takes no account of the handling and distribution of the grain and its manufacture into food products and their ultimate purchase and use by the consumer. In recent years the very high cost of living is calling attention to the fact that our methods of 
handling and distribution are cumbersome and more expensive than they need be. We need cooperation along the whole line, and a spirit of friendliness and fairness among all those interested in order that these conditions may be improved. The present condition calls for a careful investigation and such reorganization of our methods and practices as may be found necessary in order that the farmers' products may be more fully utilized and placed in the hands of the consumer without unnecessary waste, and at a reasonable cost.

\section{COST OF PRODUCTION*}

The cost of raising wheat varies greatly in different sections of the United States. The production of a bushel of wheat in Washington costs 20 to 35 cents; in Oregon, twenty cents; and in

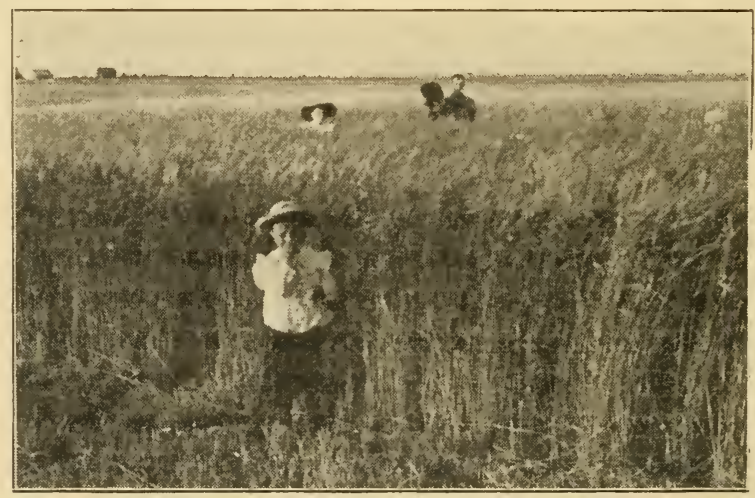

Fig. 26. - Wheat field on Burlington farm, Holdrege, Nebr. Yield, 52 bushels per acre.

*Data from Book of Wheat--Dondlinger. 
North Dakota, 50 to 54 cents. The acre cost, including interest on land and equipment, has been computed since 1900 in several states as follows:

North Dakota, \$8.28; Minnesota, $\$ 6.40$; Kansas, $\$ 7.80$; Nebraska, $\$ 8.26$; Washington, $\$ 7.20$; and Wyoming, $\$ 10.38$. This is an average cost of $\$ 8.05$ per acre or fifty-seven and one-half cents per bushel. To raise a bushel of wheat in Russia costs 34 to 48 cents; in Italy, sixty-nine cents; in Hungary, 52 to 63 cents; in Germany, ninetyfive cents; and in India, sixty-five cents. The acre cost is given as $\$ 8.00$ for Russia; $\$ 8.29$ for Argentina; and $\$ 11.69$ for Hungary.

The cost of raising wheat and all kinds of small grains has been greatly reduced by the introduction of improved implements of tillage and modern harvesting machinery. To produce a bushel of wheat in the United States in 1830 required 183 minutes of human labor. In 1896 only ten minutes were required. The labor cost per bushel including both animal and human labor is stated as twenty cents in 1830, and only ten cents in 1896. The greatest saving has been in the harvesting. The human labor which is still required is quite light compared with that of 1830 .

\section{PROFIT IN WHEAT RAISING}

The actual profit in raising wheat, however, is not large. In a favorable season, bonanza farmers of the Red River valley made a profit of $\$ 3.32$ per acre, or $8 \%$ on the capital invested. This takes no account of the exhaustion of soil fertility. 
To make much profit it will be seen that the yield must be increased above the average fourteen bushels per acre. The cost of raising an acre of wheat has been greatly reduced by the introduction and use of improved machinery and by decreasing the labor cost. Now we must give more attention to decreasing the cost per bushel by increasing the acre yield. The sixty bushel yield which the writer produced at the Kansas experiment station in 1906 cost less than fifteen cents per bushel.

The price of wheat on the market depends on the grade. It is therefore of great importance that every farmer be familiar with the methods of scoring and grading grain.

\section{SCORING WHEAT}

Judging and scoring of grains is now a regular part of the course of study in our agricultural colleges. The methods and score cards used in different institutions vary considerably. When a sample of wheat is examined from a "seed standpoint," purity, color, weight, uniformity, quality and vitality are noted. From a "market standpoint," weight and quality are the main points considered, but purity as regards freedom from foreign substance, other grain, or other types of wheat is also given an important place. The weight of wheat is indicated by its plumpness and dryness. Damp grain or shrunken grain is light. The quality relates not only to the weight, the soundness and dryness of the grain, but also to its composition or flour-making value as indicated by the texture, hardness or softness of the kernel, and the relative thickness of the hull. 


\section{SCORE CARD}

The score card given below brings out the points mentioned as well as any perhaps, but the reader is advised to get in touch with the agricultural college of his own state in order to secure special information which may apply to the grading or scoring of wheat in a particular territory or market.

\section{STUDENT'S SCORE CARD*}

\section{WHEAT}

Name of variety

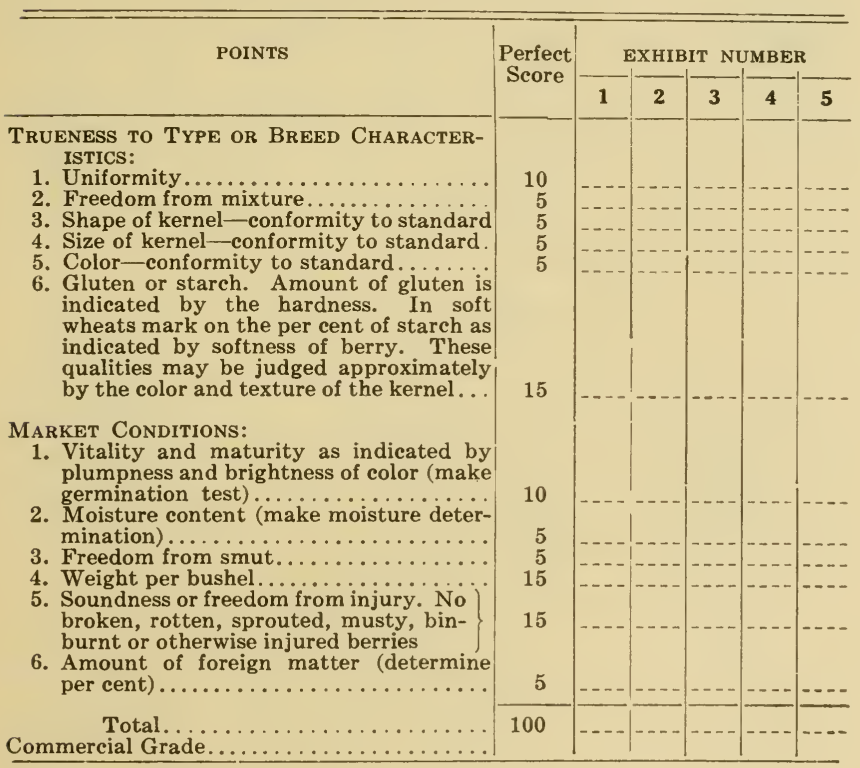

Student's Name.

Date

*Note-This form of score card, used at the Kansas Agricultural College, was prepared by the author. 


\section{CHAPTER VIII \\ WHEAT ENEMIES}

WEEDS

Weeds damage wheat both by reducing the yield and injuring the quality of the grain. The most objectionable weeds associated with wheat fields are chess or cheat, wild oats, cockle, wheatthief, and wild mustard. All of these are annuals and readily controlled by careful preparation of the seed bed and a proper rotation of crops. Weed pests become troublesome only where wheat is grown continuously in the same fields. The growth of weeds is a protest of nature against the practice of continual grain cropping. There is no remedy except rotation of crops, and clean cultivation or clean summer fallow.

\section{INJURIOUS INSECTS}

It is impossible in this discussion to more than touch on this part of the subject. The insects and diseases which attack wheat often seriously injure or destroy the crop, and in some cases there is little or no means of preventing the damage.

\section{CHINCH BUG AND HESSIAN FLY}

Of the insect enemies the chinch bug and the Hessian fly are perhaps the most destructive. The remedies to stop their ravages are preventive only, such as burning over the stubble land, which allows the chinch bug no cover for hibernating, and destroys the Hessian fly, since the insect 


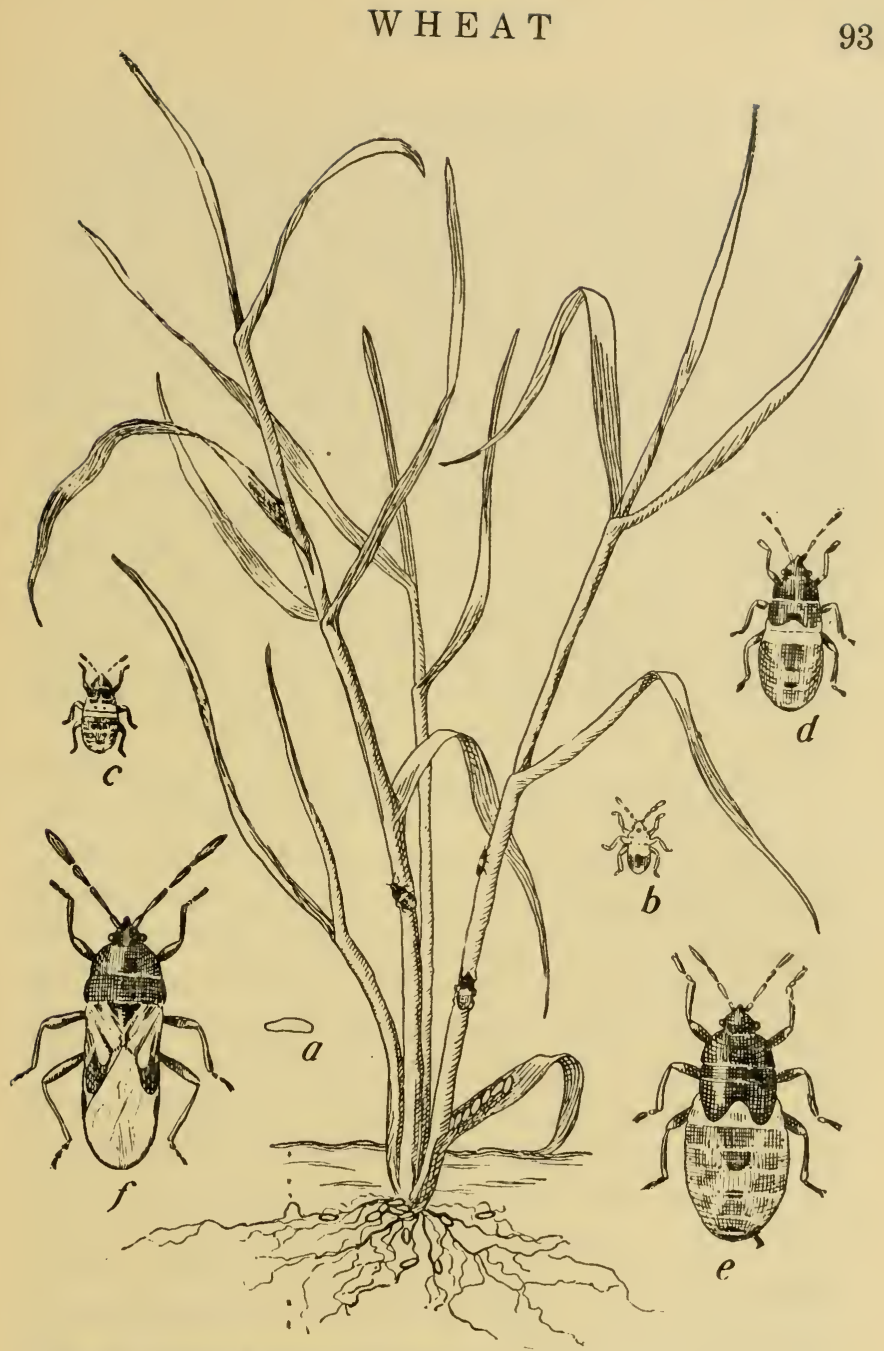

Fig. 27.-The Enemies of Wheat.-Chinch-bugs in different stages of growth. A single egg is shown in $a$, and others on the roots and a lower leaf; in $b$ is shown a very young bug, and in $c, d$, and $e$ the later stages, while $f$ shows the adult and mature insect. The natural size of the bugs is shown on the stems of the plant. 
remains in the pupa stage in the stubble after harvest. "Trap crops" are sometimes sown for both insects, such as patches of millet planted early in the spring to attract the chinch bug, and the early planting of wheat in the fall to act as a decoy to attract the flies. When the bugs have congregated or the flies have laid their eggs, these crops may be plowed under, thus destroying the insects. Migrating chinch bugs may be kept out of the fields to some extent by plowing protecting furrows about the fields, and making coal tar barriers, etc. Under certain favorable climatic conditions chinch bugs may be largely destroyed by fungous diseases to which they are subject. The Hessian fly appears early in the fall, and its attacks may be avoided by late sowing.

At the Kansas experiment station (Manhattan) the average of several trials shows results favoring seeding during the last week in September or the first week in October. Even later seeding is less affected by the fly, but the very late sown wheat is likely to make a weak growth in the fall, and is more liable to be winter killed than earlier sown wheat. Perhaps one of the best means for checking these insect pests and the plant diseases which attack wheat, is to practice a regular system of crop rotation. The Hessian fly can be starved out almost completely by the abandonment for one year of the crops in which it breeds-wheat, rye and barley; while if a system of rotation with corn be adopted that would entirely dissociate small grains for a single season very little damage from chinch bugs would occur. 


\section{GRAIN WEEVILS}

There are several species of grain weevils which attack and often severely damage stored wheat. The two most common in the United States are the granary weevil, the adult insect of which is a small snouted beetle, and the grain moth or angoumois. The larvae of these insects and also the beetle itself attack the wheat kernels, devouring the mealy part. They develop and multiply very rapidly. The remedy is fumigation with bisulphide of carbon, one pound to one ton of grain or to 1,000 cubic feet of empty space. Hydrocyanic acid gas is used for fumigating mills and large grain elevators. Naphthaline is the most effective preventive.

\section{FUNGOUS DISEASES-RUST AND SMUT}

Among plant diseases, rust and smut are perhaps the most destructive. There is no remedy for rust other than the breeding of rust-resistant varieties of wheat, and so far no fully rustresistant varieties have been produced, although certain varieties growing side by side in a field often show a different susceptibility to the attacks of rust. This may be due, however, to different periods of maturing and to weather conditions as much as to the variety.

It is estimated that the damage by stinking smut in many seasons amounts to $10 \%$ of the total wheat crop of the United States, while certain fields may show a much larger percentage of damage. This disease may be almost wholly prevented. In 
threshing smutty wheat the smut balls break and the small, dust-like spores adhere to the wheat kernels. When such wheat is planted the smut spores sprout and produce a fungous growth which infects the young wheat plant and grows within it, fruiting and forming its spores in the head of the wheat, taking the place of the grain. Any treatment which will destroy these spores without injuring the grain of wheat will prevent smut. Several treatments have been more or less successfully used, as hot water, copper sulphate or bluestone, corrosive sublimate, and formaldehyde.

\section{TREAT WITH FORMALDEHYDE}

The best remedy known for stinking smut in wheat is to treat the seed with a solution of formaldehyde. Use one pound of formaldehyde $(40 \%$ strength) to forty gallons of water. Either spray the wheat or dip it into a barrel or tank containing the solution, taking care that the grain becomes thoroughly wet. The wet grain may be left in piles and covered with blankets for a few hours in order to retain the formaldehyde gas and insure the destruction of all the smut spores. Then spread the grain quite thinly on a tight floor or canvas and allow it to dry from twelve to twentyfour hours, shoveling it over once or twice. Care should be taken not to allow the wet grain to heat in the pile. The usual method is to treat one day the seed that is to be sown the next day. The wheat thus treated will swell some, and in order to sow the required amount per acre the drill 
should be set to sow about one-fifth to one-fourth more grain than the usual amount. If the smut spores adhering to the wheat grains are destroyed, there is little danger from the smut spores that may remain in the soil coming into contact with the young wheat plants, and the resulting crop should be practically free from stinking smut.

Formaldehyde is a poison, and if the treated wheat is eaten by poultry or other livestock while it is wet it is likely to injure or kill the animals, but when the wheat has become fairly dry there is no danger from feeding the treated grain because the formaldehyde evaporates and no poison will remain in the wheat.

Loose smut of wheat is less injurious than hidden or stinking smut, but it is harder to control. Loose smut destroys the heads and grain the same as stinking smut but it matures earlier and the smut spores are scattered by the wind while the wheat is growing. Some of these spores fall into the glumes of the growing wheat and sprout, and infect the kernels and make some growth before the grain reaches maturity. These young smut plants remain dormant from the time the wheat matures until the grain is planted, when they start growth again with the sprouting wheat, and growing within the wheat plant reach maturity forming spores on the spike where the wheat grain should have formed. These blackened or bare spikes occur soon after the wheat reaches the full heading stage.

It is difficult to destroy the young smut plants which have started within the wheat kernels. 
Ordinary treatments for stinking smut do not kill loose smut but loose smut may be destroyed by treating the infected seed grain with hot water. This treatment is also effective for destroying stinking smut.

HOT WATER TREATMENT FOR LOOSE OR STINKING SMUT OF WHEAT*

Dip the wheat in hot water at a temperature of from 132 to $133^{\circ}$ Fahrenheit. The seed should be placed for the purpose in a coarsely woven basket covered with wire netting, or else in a coarse gunny sack. The basket or sack must not be filled full, as the grain must be loose inside. There should be six or eight times as much hot water as the bulk of the grain to be treated, and the temperature of the water must be kept at the right point by letting in steam, or by adding hot water from time to time if necessary. The grain must be lifted out of the water four or five times during the treatment and allowed to drain. This is needful to insure that all the grain comes into intimate contact with hot water at the right temperature.

If not convenient to keep the water at 132 or $133^{\circ}$ it may be allowed to go higher, but the treatment must be shortened, and at $145^{\circ}$ the treatment must not be prolonged beyond five minutes, and care must be taken that the water is even in temperature throughout; otherwise some grain

*The above treatment for stinking smut is given in Farmers Bulletin No. 250,United States Department of Agriculture 
will be killed and other grain insufficiently treated so the smut will not be killed.

If steam is available the water can easily be heated by conducting a steam pipe into the vessel. The steam, in getting in, heats the water and at the same time stirs it thoroughly. The hot water treatment requires no outlay at all for chemicals, but requires careful attention and considerably more labor than any of the other treatments. If properly carried out it is undoubtedly the best treatment for all kinds of grain smuts.

After removing the grain from the hot water, spread on a clean floor or on a piece of canvas to dry. The layer of grain should not be more than three inches thick. If it cannot be spread out at once, dip in cold water and set to one side until it can be attended to. It dries best if spread while hot. After one portion is spread out another can be treated, and so on, until all the seed has been disinfected.

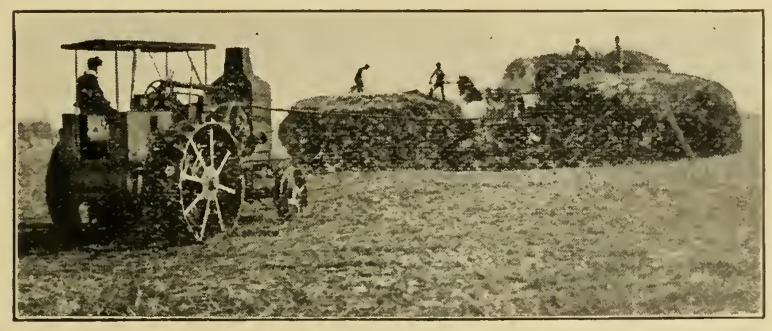




\section{CHAPTER IX}

\section{MAINTAINING SOIL FERTILITY}

Our agricultural teaching and modern methods of farm practice have resulted in largely increased crop yields at the expense of soil fertility. Experiment stations and many farmers have been busy investigating and applying better tillage methods in the growing of wheat, and this is well. As the writer has determined by experiments it is possible to double the yield of wheat in a single season by careful and timely preparation of the seed bed; but the scientific tillage of the soil should be combined with crop rotation, green manuring and the use of barnyard manure and other necessary fertilizers, or it will degenerate into a mining proposition-mining the soil of its fertility.

In a sense, "tillage is manure" because the favorable conditions produced by the cultivation of the land cause the plant food in the soil to become available faster than would be the case without tillage. But good tillage alone will not keep the soil fertile; rather it may cause the fertility of the soil to become exhausted more rapidly by the production of larger crops. There is also a tendency to waste the soluble plant food by drainage and soil drifting. The great problem in western wheat farming today is not how to get larger yields out of the soil for a few years, but rather how to produce paying crops every year and at the same time maintain the potential fertility and productiveness of the land. 
CONTINUOUS CROPPING THE MAIN FAULT

The fault with most wheat producing sections is that the land is cropped with wheat too continuously. The continuous growing of wheat on the same soil has always proved disastrous in the course of years. This has been the history of wheat farming, and largely on this account the wheat-growing area of the United States has moved ever westward. It appears now that most of the land available for the growing of wheat has been taken, and if wheat raising in this country is to continue to be profitable there must be a change in our methods of farming.

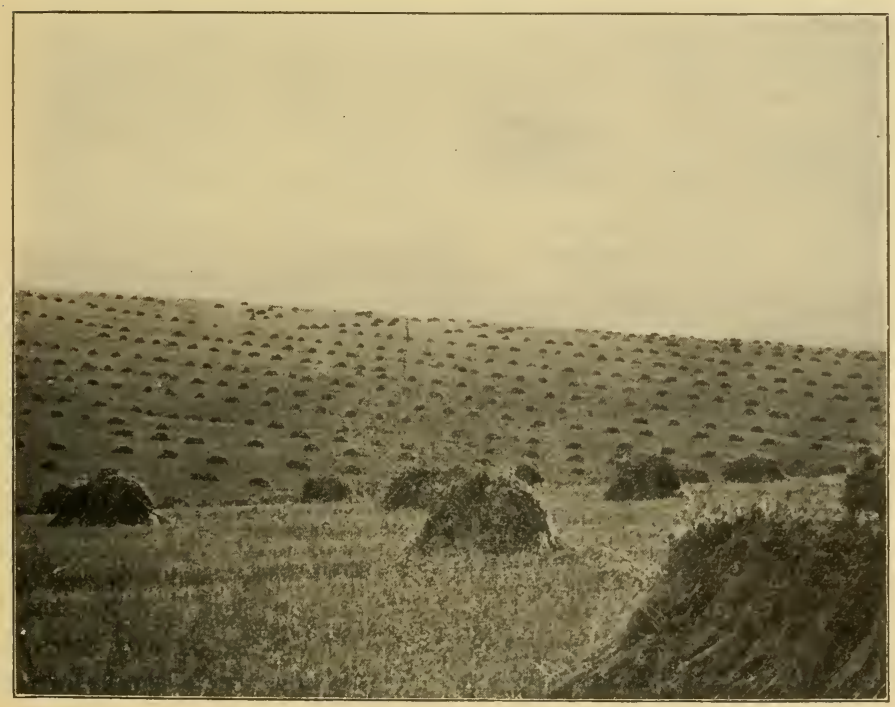

Fig. 28. - A typical Montana wheat field. Millions of acres like these are still waiting for the plow. 


\section{WHEAT SICK LAND}

Fertile land which has been cropped with wheat for a long time becomes "wheat sick." It is not necessarily exhausted in fertility - it needs a rest, a change of crop. The soil is likely to become exhausted in nitrogen and organic matter and humus, and it may become deficient in some of the mineral elements of plant food. But the problem of reduced yields is not a matter of plant food alone. The continuous cropping with wheat infects the soil with plant diseases and injurious insects, and the loss of organic matter and continuous tillage destroys the ideal texture and tilth which characterized the virgin prairie when it was first broken. What the old wheat land needs worst and first is a proper rotation of crops which will serve to aerate the soil and free it of weeds and infectious diseases and injurious insects, and at the same time renew the supply of organic matter and nitrogen.

\section{ROTATION PLANS}

In planning rotations, four general classes of crops should be provided for if conditions will allow:

1. A "money" crop, or crop to be sold, which may remove from the soil considerable quantities of plant food.

2. A leguminous crop to return nitrogen and organic matter to the soil, and also by its deep root system to collect subsoil phosphorus, potassium and lime. 
3. (a) A crop for feeding farm animals, the plant food of which is largely returned to the soil in manure; (b) a crop for green manure in case livestock raising is not a part of the farming plan.

4. An intertilled crop for destroying weeds and improving the physical and sanitary conditions of the soil.

The arrangement or order of crops in a rotation system should follow as far as possible these rules:

1. To alternate shallow and deep rooted crops.

2. Crops which furnish organic matter should alternate with those which favor its rapid decomposition.

3. Use at least one leguminous crop in the rotation in order to increase the supply of plant food in the soil.

4. Crops in rotation should vary in time of planting, cultivation, and harvest season as much as possible, and in amount and kind of their plant food requirements.

5. (a) Commercial fertilizer should be applied to the special crop which will be most benefited by its use, such as wheat, clover, or alfalfa. Manure should be applied to the hardy, more vigorous growing crops, such as corn and forage crops or grasses and clover which should precede wheat.

The kinds of crops in the rotation will depend upon the climatic and soil conditions, the market requirements and the kind of farming. In the more humid sections ideal rotation systems are not difficult to plan and execute. The following 
are some wheat rotations in practical use which include most of the requirements named:

1. Wheat, clover, potatoes-three year rotation.

2. Wheat, clover, corn, oats-four year rotation.

3. Wheat, clover and timothy (2 years), corn, oats-five year rotation.

4. Wheat (2 years), alfalfa (5 years), corn (2 years), oats - ten year rotation.

5. Wheat, wheat plus catch crop of cowpeas, corn, oats - four year rotation.

6. Wheat, wheat, cowpeas - three year rotation.

7. Wheat, corn and cowpeas, oats - three year rotation.

It is possible to use barley or other small grain in place of oats. Other green manure crops may be used instead of cowpeas, such as sand vetch, field peas, sweet clover, crimson clover, etc.

\section{ROTATION FOR SEMI-ARID LAND}

A regular and systematic rotation of crops is not so easily adopted and carried out in the semiarid regions, but the following plans may be successfully used:

1. Wheat, flax, fallow-three year rotation.

2. Wheat, corn, flax - three year rotation.

3. Wheat, flax, corn, oats - four year rotation.

4. Wheat (4 years), grasses and legumes (5 years), corn-ten year rotation.

5. Wheat (2 years) green crop with fallow, corn-four year rotation. 


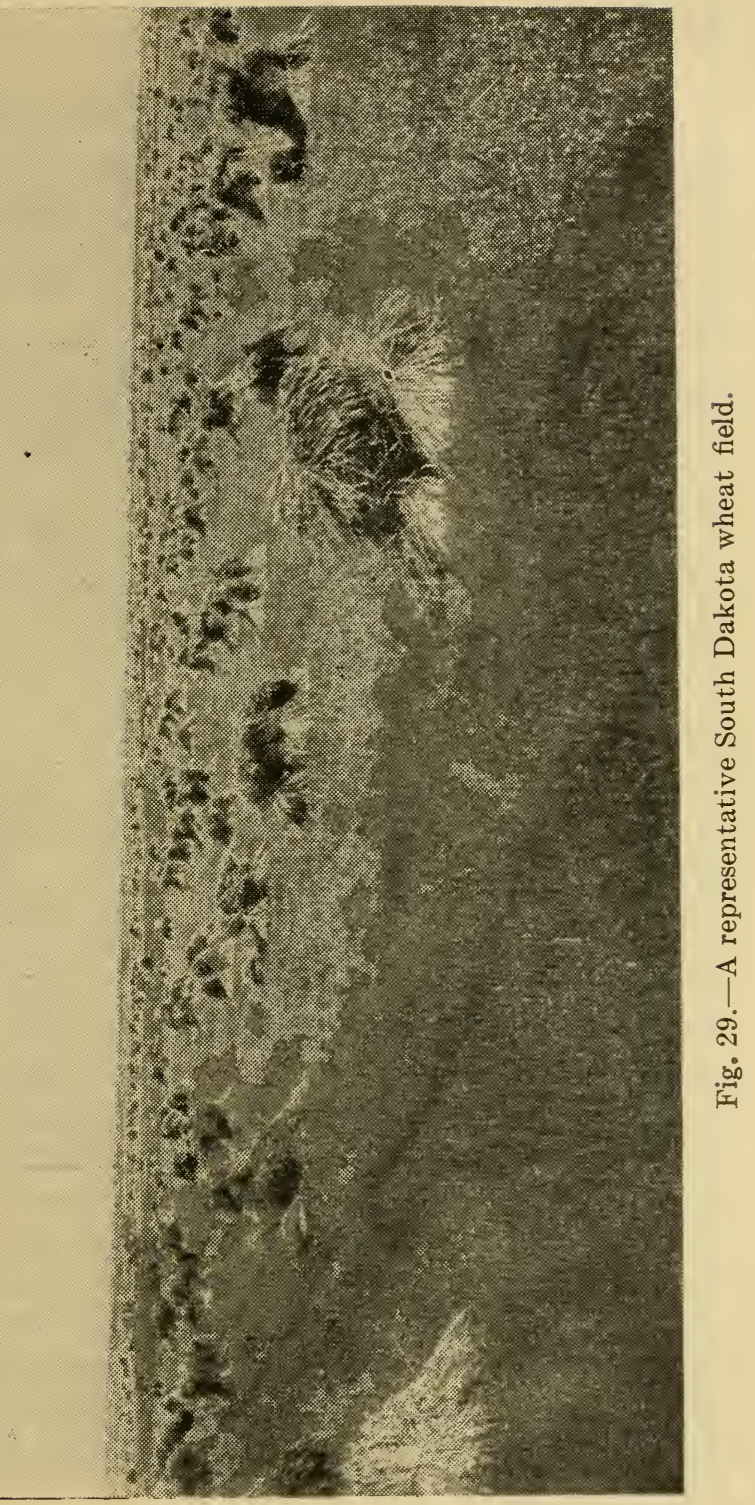


6. Wheat, kafir (or other sorghum), fallowthree year rotation.

7. Wheat, wheat plus green manure, kafir, fallow-four year rotation.

8. Wheat (2 years), kafir, green crop with fallow-four year rotation.

9. Wheat, corn (or other forage), oats plus green manure, fallow-four year rotation.

10. Wheat, corn, cowpeas with fallow-three year rotation.

Alfalfa may be grown successfully and used in rotation in the more favorable soils of the semiarid regions. The first five plans are adapted to the northwestern spring wheat area, where it is difficult to use leguminous or green manuring crops. The last five may be successfully practiced in Kansas and the southwest in the growing of winter wheat. Plan No. 6 is now being practiced on the 3,600 acre experimental farm at Fort Hays. One-third of the tilled upland on this farm is planted to wheat each year, one-third to intertilled and forage crops, mainly kafir, milo and sweet sorghum, and one-third remains fallow each year, making no crop and receiving summer culture. During the year of fallow the land should receive a dressing of manure, or early planted crops may be plowed under for green manure. Wheat follows the summer fallow and the forage crops and the sorghums follow the wheat, thus every year the great income producing crop, wheat, is grown under the most favorable conditions. Where conditions are more humid two or three crops of wheat may be raised after fallow before the field is planted again with sorghums. 


\section{MIXED FARMING}

Such a system of farming compels the raising of livestock to consume the forage, and this will necessitate the building of silos and forage barns to save the forage in large enough quantities so that there will always be a reserve supply to tide over a very dry season and thus make dry farming permanent and sure. In the dry farming areas of the Pacific slope and in the drier parts of the western plains and mountain states where dry farming is practiced, alternate cropping and bare summer fallowing seems to be as yet the most practical method of maintaining crop yields. Perhaps haps the future may develop green crops which may be successfully used for green manure in these dry areas in order to restore the decreasing soil humus and organic matter. Under irrigation it is possible to introduce one or more of the rotation plans in use in humid climates, with perhaps some variation in the kinds of crops.

INFLUENCE OF CROP ROTATION ON WHEAT YIELDS

The influence of individual crops in rotations on succeeding wheat yields is shown by a long series of experiments at the North Dakota experment station, in which wheat was grown after each of several crops each year for three years in succession in four year rotations, thus eliminating the effect of seasons. As assistant agronomist at the North Dakota experiment station the writer had the privilege of conducting this work for five years (1898 to 1902) and started this particular series of rotations. The results taken from 
North Dakota bulletin No. 100, by Shepperd and Doneghue, are given below.

\section{TABLE V}

Showing increase in yield per acre of wheat after various crops, compared with wheat after wheat.

\begin{tabular}{|c|c|c|c|c|}
\hline Wheat After & $\begin{array}{l}\text { 1st Yea: } \\
\text { Eushels }\end{array}$ & $\begin{array}{l}\text { 2d Year } \\
\text { Eushels }\end{array}$ & $\begin{array}{l}\text { 3d Year } \\
\text { Eushels }\end{array}$ & $\begin{array}{c}\text { Total } \\
\text { Increase } \\
\text { Bushels }\end{array}$ \\
\hline 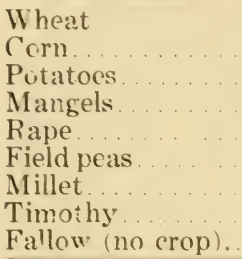 & $\begin{array}{l}\text { Check } \\
7.87 \\
1.49^{*} \\
6.95 \\
7.55 \\
6.53 \\
7.41 \\
1.84 \\
7.45\end{array}$ & $\begin{array}{r}\text { Check } \\
7.57 \\
13.29 \\
8.57 \\
8.84 \\
1.93 \\
5.99 \\
8.50 \\
3.46\end{array}$ & $\begin{array}{r}\text { Check } \\
2.40 \\
4.17 \\
2.10 \\
3.29 \\
0.29 \\
2.26 \\
6.16 \\
2.39\end{array}$ & $\begin{array}{l}\text { Check } \\
17.9 \text { t } \\
15.97 \\
17.62 \\
19.68 \\
8.75 \\
15.6 \text { i } \\
16.90^{* *} \\
13.29\end{array}$ \\
\hline
\end{tabular}

*Decraas.

**There was 6.76 bushels increase in yie.d thə f Jurth y za:.

There was no ircrease in yield of wheat, as an average, after flax or other small grains. The largest total increase in wheat yields for three years was 19.68 bushels per acre, after rape. The second largest was 17.84 bushels after corn. The average "check" yield of wheat after wheat, in corn series was 15.35 bushels per acre; in the rape series, 16.14 bushels per acre.

\section{FERTILIZER NEEDS OF WHEAT}

The plant food constituents in a normal wheat crop of twenty-five bushels per acre, also in a normal crop of corn, oats, clover, alfalfa, and the fertility in manure and some other fertilizers together with its value, are given in Table VI. 


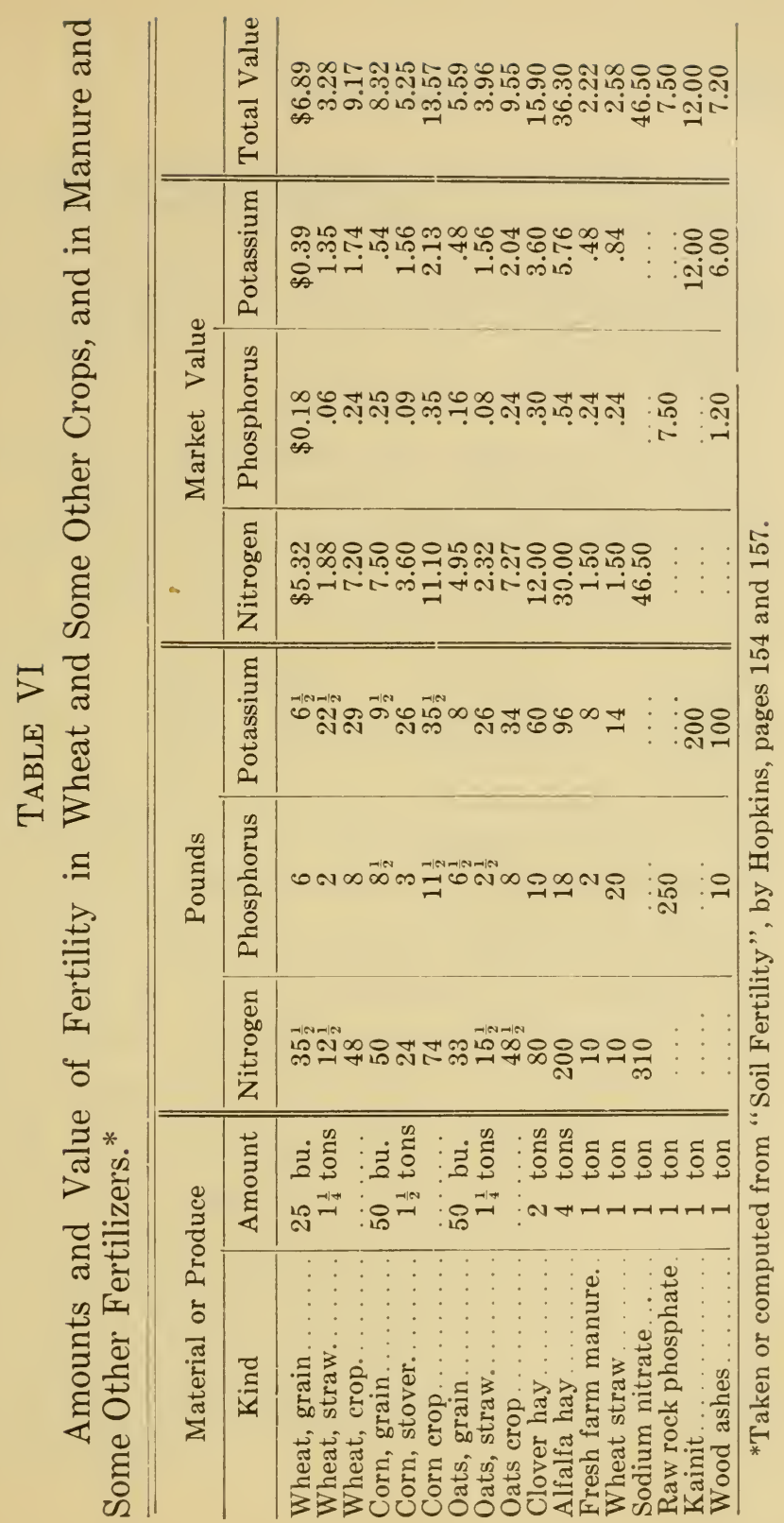


The values of the fertilizing constituents are calculated at the market price of car lots as follows:

Nitrogen in sodium nitrate...........15c per pound Phosphorus in ground rock phosphate....... 3c per pound Potassium in kainit................6. 6 per pound

\section{TABLE VII}

Amounts of plant food constituents in fertile soils: ("Fertilizers and Crops" by VanSlyke)

\begin{tabular}{l|r|rr}
\hline Constituents & Percent & $\begin{array}{r}\text { Pounds in one Acre to Depth } \\
\text { of Nine Inches }\end{array}$ \\
\cline { 1 - 1 } & & & \\
Nitrogen...... & 0.10 to 0.30 & 2,500 to 7,500 & Average \\
Phosphorus ... & 0.03 to 0.11 & 750 to 2,750 & 1,750 \\
Potassium ..... & 0.80 to 1.60 & 20,000 to 40,000 & 30,000 \\
Calcium..... & 0.20 to 1.50 & 5,000 to 37,500 & 21,250 \\
\hline
\end{tabular}

The average weight of an acre of soil to the depth of nine inches is taken as 2,500,000 pounds. The great bulk of the soil consists of inert materials, as clay and sand, composed largely of aluminum and silica. The plant food constituents are present only in relatively small proportions. The combined amounts of nitrogen, phosphorus and potassium in fertile soils are usually less than $1 \%$ and only a very small proportion of these small amounts are in forms immediately available for the use of plants. Considering the small amounts required by crops, the supply of plant foods in the soil will theoretically last a very long time. For instance comparing Tables V and VI it will be seen that the average fertile soil contains enough phosphorus in nine acre-inches to produce more than 200 twenty-five bushel wheat 
crops; enough nitrogen for 1,000 crops and enough potassium for 10,000 crops. It is true also that many subsoils to the depth of several feet at least, are often as rich in the mineral plant foods as the surface soil. We know that in practice however, a very fertile soil will not continue productive by continuous cropping without fertilization for even 100 years. After thirty or forty years of continuous wheat cropping, the fertile Red River Valley lands are showing decreasing yields. In fact a considerable area of this splendid land is now being abandoned for wheat culture because it will not produce yields large enough to pay for the farming.

One reason for this condition is the waste of soluable plant food by oxidation and drainage, especially the nitrogen and the lime. It was found at the Minnesota experiment station that in growing eight crops of wheat continuously, enough nitrogen disappeared from the soil to produce nineteen other crops of wheat-thirty bushels per acre. Again the mineral plant foods are locked up and become unavailable in soils which reach an unfavorable physical condition, due to continuous cropping and loss of organic matter.

\section{WHEN DOCTORS DISAGREE}

It is evident therefore that theory and practice do not agree. Land cannot be cropped for a long time without fertilization and remain productive. It is also evident that nitrogen, lime and phosphorus are the limiting elements in soil productivity. 
Hopkins is authority for the statement that the fertility of all normal soils in the United States may be permanently maintained and even increased by adopting systems of farming which will supply three constituents regularly and in proper amounts, namely, limestone, phosphorus and organic matter. The limestone is required to correct acidity, and is most cheaply applied in the form of ground limestone rock as a surface dressing. The phosphorus is needed solely for its plant food value, and its most economical source is ground rock phosphate. The supply of organic matter must be renewed to provide nitrogen and to keep the soil in favorable physical condition. It has to do also with making available the potassium and other essential plant food elements contained in the soil in abundance.

The ideal farm practice is to return to the soil all plant food not sold from the farm. The organic matter may be in part maintained by plowing down the stubble and by saving the straw and manure and returning it again to the soil.

Investigations at several experiment stations have determined that about one-third of the total organic matter and nitrogen in a red clover plant is contained in the roots and stubble. Alfalfa contains a larger proportion of nitrogen in its roots, while sweet clover and crimson clover may contain a little less than red clover. If a crop of any of these legumes is plowed under for green manure there is added to the soil a definite amount of organic matter and nitrogen which may be readily computed. Thus the plowing under of a crop of 
clover equivalent to a ton of dry hay will add forty pounds of nitrogen per acre besides that contained in the roots of the clover.

From Table VII it may be readily determined how much manure or other fertilizer will be necessary to use to return to the soil the amounts of plant food removed by a twenty-five bushel wheat crop, and normal yields of other crops used in rotation.

In a four year rotation of wheat, corn, oats and clover, the supply of organic matter and nitrogen should be maintained by the rotation of clover and by the application of fifteen tons of manure every four years to the clover sod before plowing for corn; or in the case of grain farming without much livestock, the plowing under of one crop of clover with the addition of nine tons of manure per acre will supply the required nitrogen. Fifty pounds of rock phosphate applied with fifteen tons of manure, or one hundred pounds applied with nine tons every fourth year, will maintain the phosphorus content of the soil.

It is possible to keep up the nitrogen supply without manure by using the rotation with clover, and plowing down the second cutting and adding a catch crop of cowpeas, planted after wheat and plowed under in the fall, preceding corn. This plan would require the use of 250 pounds of phosphate rock to maintain the phosphorus. If the soil becomes acid or is lacking in lime, it should receive an application of from one to three tons of ground limestone per acre every fourth season. If there is an abundant supply of phosphate in 
the soil, it will doubtless not be necessary to use more than one-half of the theoretically required amount of phosphate in order to insure the production of normal crops; a heavier application would make larger yields possible.

Other commercial phosphate fertilizers are superphosphate, bone meal and Thomas slag. These forms may be used in place of the ground rock phosphate but are rather more expensive. There are other commercial fertilizers which may be used to advantage on some soils but it seems best not to mention them here lest it confuse the reader.

\section{METHODS OF FERTILIZATION}

If commercial fertilizers are used in growing wheat, they had best be applied to the wheat crop at seeding time by the use of a fertilizer drill. Manure may be applied directly to wheat, preferably as a surface dressing after seeding and often with good results. The writer increased the yield of wheat thirty per cent on upland at the Kansas experiment station, by applying ten tons of well rotted manure per acre as a surface dressing to fall wheat. Coarse strawy manure should not be used for this purpose. A better plan is to supply the necessary plant food for the wheat crop by manuring or fertilizing other crops in the rotation. The manure may be profitably applied to corn, alfalfa, clover or grasses, and the clovers and grasses respond well also to phosphate and limestone.

There is a double advantage in applying fertilizer to the legume crop, since it not only causes 
an increased yield of the legume, but a greater storage of plant food in the roots of the legume crop, due to the increased growth, and this increase in the fertility of the soil will be available to the crop which follows the legume.

\section{HOW TO USE MANURE}

Manure should not be applied in too heavy applications, a light dressing of eight tons of manure per acre over forty acres will give a greater relative increase in the crop and greater value to the manure than a heavier dressing of sixteen tons per acre over twenty acres leaving the remaining twenty acres unmanured. Actual experiments on a small scale have proven this statement. Also in plowing under a heavy dressing of manure there is danger that the manure, by breaking the capillary connection of the soil with the subsoil may cause the crop to "burn out" in a dry season. For the same reason it is not advisable to plow under trashy or coarse manure.

An experiment in manuring in wheat rotations carried on for twenty years at the North Dakota experiment station demonstrates the cumulative effect of manuring. Only six loads of well rotted manure was applied per acre to the corn or millet in a four year rotation with wheat. The percentage increase in yields of wheat from manuring compared with the same rotation without manure is given in Table VIII. 


\section{TABLE VIII}

Increase in wheat yield due to farm manure by periods of five years (1892-1906), Bul. No. 100 N. D. Exp. Station.

\begin{tabular}{|c|c|c|c|c|c|}
\hline \multirow{2}{*}{$\begin{array}{c}\text { Manure } \\
\text { Applied to }\end{array}$} & \multicolumn{5}{|c|}{ Percent Increase } \\
\hline & $\begin{array}{l}\text { First } \\
\text { Period }\end{array}$ & $\begin{array}{l}\text { Second } \\
\text { Period }\end{array}$ & $\begin{array}{l}\text { Third } \\
\text { Period }\end{array}$ & $\begin{array}{l}\text { Fourth } \\
\text { Period }\end{array}$ & Average \\
\hline Corn & 5.5 & 9.3 & 21.5 & $12.5^{*}$ & 12.2 \\
\hline Millet... & 6.1 & 19.1 & 33.9 & $3 ? .2^{*}$ & 19.3 \\
\hline Average. & 5.8 & 9.7 & 27.2 & $21.3^{*}$ & 15.8 \\
\hline
\end{tabular}

* Three jears only.

The average annual increase in wheat yields was nearly $16 \%$ due to the application of only six loads of manure per acre once in four years, and this was on the fertile wheat lands of the Red River Valley.

\section{THE VALUE OF WHEAT STRAW}

Observe from Table $\mathrm{V}$ that a ton of wheat straw contains about the same amount of plant food elements as a ton of farm manure but it is difficult to use the straw directly as a fertilizer because of its bulky, trashy character. In the great wheat producing areas it seems necessary to burn a great deal of straw simply to get it out of the way. When burning is necessary, it is better to spread the straw over the field and burn it rather than to burn it in piles. By spreading, the ashes will be distributed over the land and the nitrogen only will be lost in burning.

The introduction of a proper rotation of crops 
will largely do away with the necessity of burning the straw. Wheat straw has some feeding value but perhaps the best use for it is as bedding in the stable and in the yards where it may fulfill a double purpose; to provide a suitable bed for stock and also as an absorbent for the manure, especially the liquid excreta of the animals, the fertilizing value of which is greater even than that of the solid excrement. After being tramped and partially decayed, the straw itself makes good manure and may be readily incorporated with the soil.

\section{GREEN MANURING WITH SUMMER FALLOWING}

The soils of the Great Plains are usually abundantly rich in mineral plant foods and it is doubtful if the application of phosphates or lime is necessary in order to increase yields, but these same soils are and always have been lacking in organic matter and the continuous cropping has rapidly depleted the natural supply. It has been found difficult to rotate crops in semi-arid regions so as to restore the organic matter.

The method of green manuring and partial summer fallowing which has been put into practice at the Ft. Hays, Kansas experiment station is in the judgment of the writer an advantage over bare summer fallowing and largely overcomes the objections to summer tilling. The plan is to plant a fall crop or early spring crop and plow it under late in May or early in June, practicing a summer fallow with surface cultivation (summer tillage) for the balance of the season until seeding 
time. Certain crops adapted to the west are being tested for this purpose; the most promising are sand vetch and sweet clover for fall seeding and field peas for spring seeding. These crops are hardy rapid, growers and somewhat drouth resistent and may be used in part for pasture, thus giving some return other than their fertilizing value.

\section{VARIOUS EXPERIMENTS}

Wheat sown directly after green manuring with field peas, has not given as high yields as when sown after a bare fallow. Sand vetch is safer to use because it may be seeded in the fall and is ready to plow down early in the spring.

An experiment in green manuring in wheat rotations at the North Dakota experiment station indicates, that as the supply of organic matter decreases, the benefit from green manuring increases. This experiment has been carried on for twenty years, a crop of field peas or millet being plowed down every fourth year. The results of green manuring on the succeeding yields of wheat compared with the same rotation in which the peas and millet crops were harvested is given in Table IX.

\section{TABLE IX}

Showing the influence of green manuring upon wheat yields by periods of five years (1892-1906), Bul. No. 100 North Dakota experiment station: 


\begin{tabular}{|c|c|c|c|c|c|}
\hline \multirow{2}{*}{$\begin{array}{c}\text { Green Manured } \\
\text { With }\end{array}$} & \multicolumn{5}{|c|}{ Percent Increase or Decrease } \\
\hline & $\begin{array}{l}\text { First } \\
\text { Period }\end{array}$ & $\begin{array}{l}\text { Second } \\
\text { Period }\end{array}$ & $\begin{array}{l}\text { Third } \\
\text { Period }\end{array}$ & $\begin{array}{l}\text { Fourth } \\
\text { Period }\end{array}$ & Average \\
\hline $\begin{array}{l}\text { Field peas... } \\
\text { Millet...... }\end{array}$ & $\begin{array}{l}-9.6^{*} \\
0.6\end{array}$ & $\begin{array}{l}-6.9^{*} \\
-7.0^{*}\end{array}$ & $\begin{array}{l}33.2 \\
10.0\end{array}$ & $\begin{array}{l}17.6 \\
10.5\end{array}$ & $\begin{array}{l}8.6 \\
3.5\end{array}$ \\
\hline Average..... & $-4.5^{*}$ & $-7.0 *$ & 21.6 & 14.1 & 6.1 \\
\hline
\end{tabular}

*Decrease.

The negative results during the first two periods are more than off-set by the positive increase in yields in the last two periods. It should be remembered also that this North Dakota soil (the typical Red River Valley wheat lands) is far richer in organic matter than the average soil of the Western Plains.

\section{DANGER OF GREEN MANURING}

The danger from green manuing is that the seed bed will be left too loose the first year with a tendency to dry out and injure the crop. Also, the wheat is apt to produce too rank a growth of straw, the first crop after green manuring. These objections may be in part overcome by early plowing, subsurface packing and frequent surface cultivation in order to hasten the decay of the organic matter, conserve the soil moisture and secure a firm, well pulverized condition of the seed bed.

If this method of green manuring can be generally adopted, it will solve the problem for a long time at least of keeping up the supply of organic matter and maintaining the productiveness of our western wheat lands. 
In conclusion, the farmer who carries out a proper system of crop rotation, as described in these pages, growing wheat on only a part of his fields each season, may produce more wheat on one-third or one-half of his farm in the next forty years than he would produce by continually growing wheat on all his land. The crops used in rotation will give an additional profit when fed to live stock, and if the manure is saved, and returned to the soil, with perhaps a little phosphate and limestone, as may be required, the fertility of the land should be maintained and its productiveness increased. Such a practice carried on for 100 or 1,000 years should give similar results.

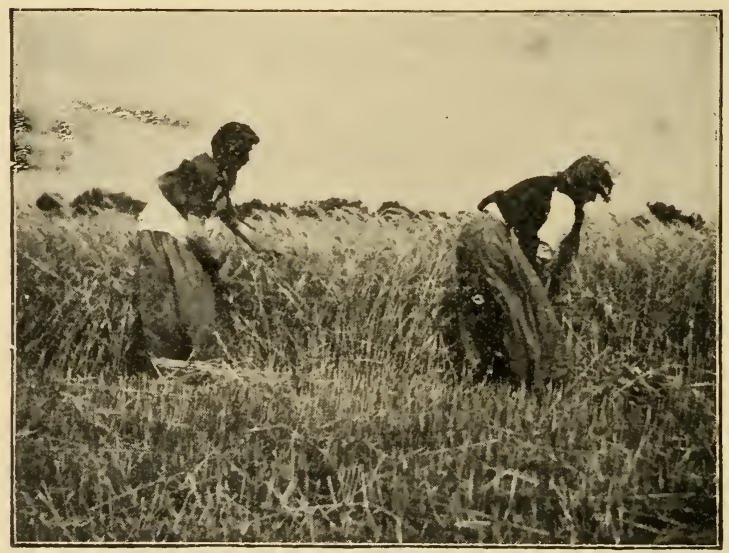




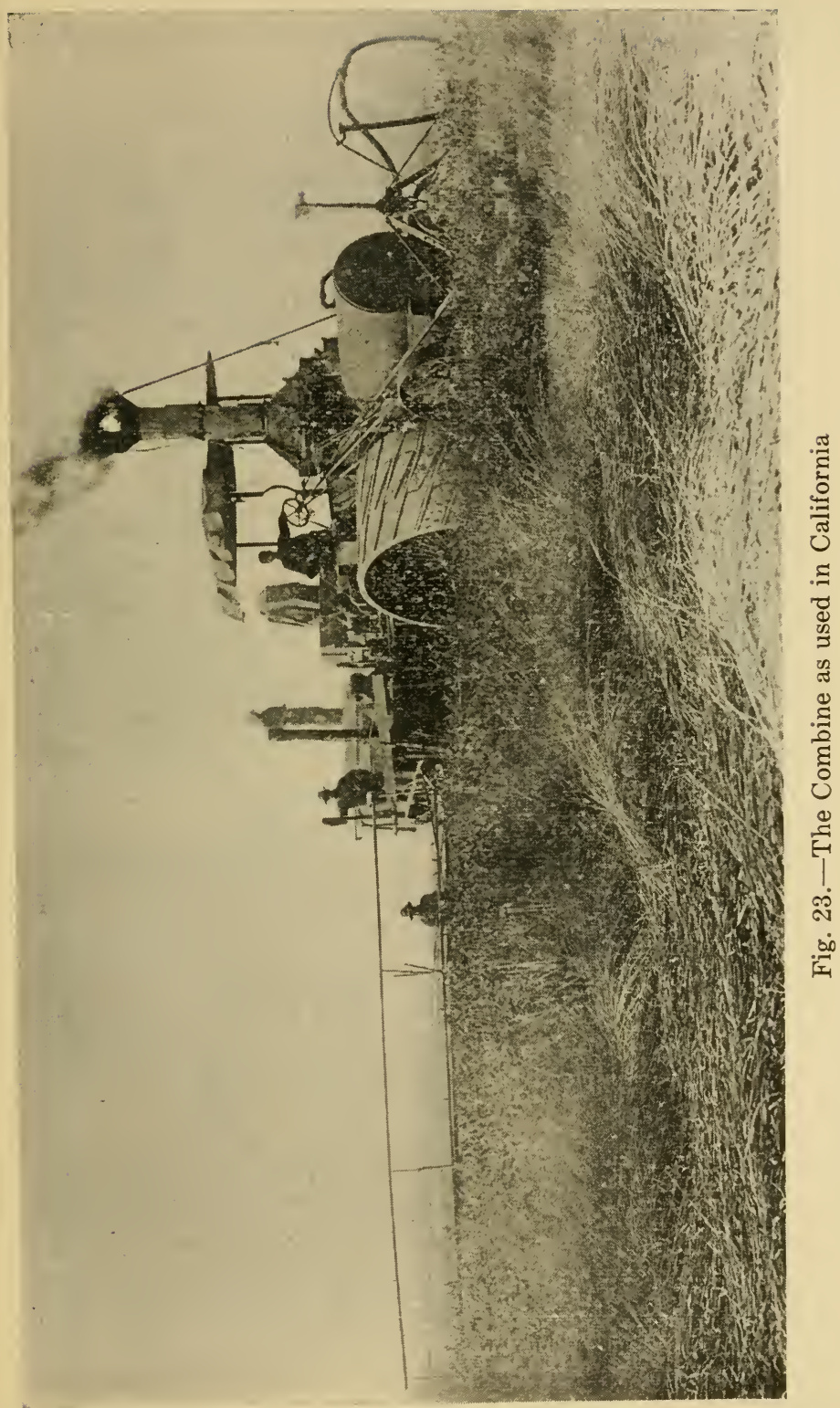




\section{Chapter X}

\section{WHEAT ON THE PACIFIC COAST}

Washington is the leading wheat producing state of the Pacific slope. Up to 1900 California exceeded Washington in wheat production. The total crop in 1900 was 28,543,628 bushels for California and 25,096,661 bushels for Washington. In 1912, Washington produced 53,414,000 bushels and California only 6,290,000 bushels. The exhaustion of California's wheat lands and the development of agriculture along more profitable lines than grain farming is given as the reason for this remarkable falling off in wheat production.

The present relation of the acreage, for both spring and winter wheat, the average yields per acre, and total production in the four wheat producing states of the Pacific coast from 1910 to 1912 are given in the following table:

\section{TABLE X}

\begin{tabular}{|c|c|c|c|c|c|}
\hline \multirow[b]{2}{*}{ STATE } & \multicolumn{2}{|c|}{ Spring Wheat } & \multicolumn{2}{|c|}{ Winter Wheat } & \multirow{2}{*}{$\begin{array}{l}\text { Total } \\
\text { Production } \\
\text { Bushels }\end{array}$} \\
\hline & $\begin{array}{c}\text { Average } \\
\text { Acreage } \\
\text { Acres }\end{array}$ & $\begin{array}{c}\text { Av'ge } \\
\text { Yield } \\
\text { per } \\
\text { Acre }\end{array}$ & $\begin{array}{c}\text { Average } \\
\text { Acreage } \\
\text { Acres }\end{array}$ & $\begin{array}{l}\text { Av'ge } \\
\text { Yield } \\
\text { per } \\
\text { Acre }\end{array}$ & \\
\hline $\begin{array}{l}\text { Idaho.......... } \\
\text { Washington.. } \\
\text { Oregon....... } \\
\text { California... }\end{array}$ & $\begin{array}{r}187,333 \\
1,139,000 \\
239,667 \\
\ldots \ldots\end{array}$ & $\begin{array}{l}25.9 \\
18.1 \\
18.4 \\
\ldots\end{array}$ & $\begin{array}{l}342,333 \\
861,333 \\
561,000 \\
600,000\end{array}$ & $\begin{array}{l}28.0 \\
25.1 \\
24.2 \\
17.7\end{array}$ & $\begin{array}{l}14,343,000 \\
43,226,000 \\
18,052,667 \\
10,676,667\end{array}$ \\
\hline Tot'l and Av'ge & $1,566,000$ & 20.8 & $2,364,666$ & 23.8 & $86,298,334$ \\
\hline
\end{tabular}




\section{LARGE SIZE OF FARMS}

Wheat farming on the Pacific coast is remarkable for the gigantic scale in which it is carried on. It is not uncommon for a single farmer to grow several thousand acres of wheat each year. Some of the larger farms exceed 5,000 acres in area. In 1907, R. C. McCroskey, near Garfield, Washington, in the famous Palouse country, harvested and threshed 46,000 bushels of wheat from a single field of 1,000 acres. This is said to be the largest crop of wheat ever grown in one field. While Washington has some of the largest wheat farms in the world, the very large farms are the exception, the average wheat farms ranging in size from 160 to 640 acres. In the other Pacific slope states the farms average less in area than in Washington.

\section{METHODS IN FARMING}

Wheat raising on the Pacific coast is carried on almost entirely by dry farming methods. Irrigation is practiced to some extent in Idaho and California, but when compared with the dry farming area the acreage is very small. Wheat is grown continuously on the same land, little or no rotation of crops being practiced in the wheat growing sections, but the usual method now coming into practice is to summer fallow the land about every third year.

Extensive farming and continuous grain cropping have exhausted the rather limited supply of nitrogen and organic matter originally contained in most of these semi-arid soils. The result is 
that grain yields are beginning to decrease, and wheat farming is becoming less profitable on the older lands, especially in California.

The Pacific coast wheat grower is up against the same problems that confront the western plains farmer - the conservation of humus and nitrogen and the maintenance of the productiveness of his soil.

In the California experiment station Bulletin No. 211, "How to Increase the Wheat Yield," Professor G. W. Shaw comments upon past and present conditions of wheat farming in Califcrnia as follows:

"The old methods of grain growing still persist in California. They are generally very simple and very crude. At first satisfactory returns were obtained because of an unusually fertile, virgin soil. At the outset there was an annual cropping of the land to the cereals with no attempt to either rotate crops or restore any of the humus that such a system destroys. In order to cover as large an acreage as possible the crudest methods of culture were practiced. The practice consisted simply of three or four-inch plowing, broadcasting the seed, and harrowing it in. But little attention was paid to the selection of pure seed, and far too often the growers purchased a second or a third grade seed under the false notion that anything that would sprout was good enough.

"The more important changes which have taken place since the introduction of the above named crude practices have been the replacing of the header and stationary thresher by the com- 
bined harvester, and the quite general introduction of the practice of summer-fallowing the land. "The development of the combined harvester has, without doubt, decreased the cost of production where grain is grown upon a large scale, but it has at the same time tended to encourage a desultory system of culture, and rendered the fields very foul through a general distribution of weed seeds, because by the time the grain is harvested in this manner practically all the serious weeds have fully ripened their seed; and further, the length of time the grain is left in the field after maturity has tended to seriously increase the loss from shattering by the wind. It is very questionable, then, whether the combined effects of these undesirable factors have not more than offset the decreased cost.

"The summer fallow (summer tillage) practice was introduced for two reasons; first, it was an attempt to save as much of two season's precipitation as possible for the production of a single larger crop; second, to clean the land of weeds resulting from continued grain culture. The latter effect has been largely offset by the use of the combined harvester.

"The shallow preparation of land and the continual practice of burning off the straw have had a very bad effect upon the humus content of the top foot of the soil, which in turn has so affected its physical condition, generally speaking, as to materially reduce its moisture capacity and seriously affect the yield of grain. Further, the earlier seeding made possible by the summer 


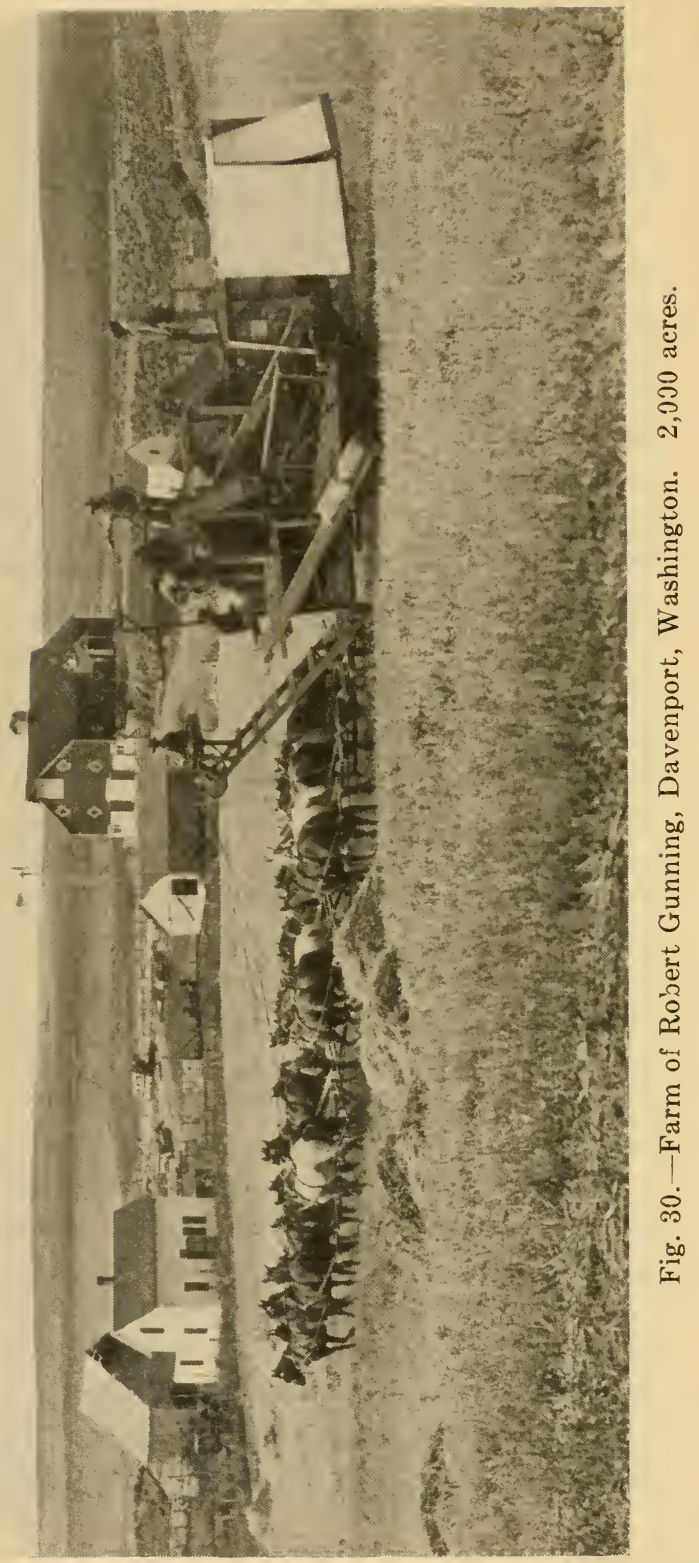


fallow practice has also reduced the quality of the grain, as shown by the analyses of a large number of samples of early and late seeded grain.

"During recent years, mainly as a result of the reduction in size of some grain farms, and the educational efforts conducted by the university of California throughout the state, there has been an increase of the depth of plowing on the part of some farmers, but in general the same careless methods of culture still hold.

"To summarize, the general effect of the past and present methods has been the development of a poor physical condition of the land, largely a result of the depletion of the humus, until the soil refuses to produce profitable yields of the commonly grown varieties of wheat under the old system of farming."

\section{CULTURE METHODS IN WASHINGTON AND}

\section{OREGON}

The culture methods practiced in Washington and Oregon are perhaps little if any better than those in California, but the newer lands in these states have not yet begun to show the decrease in yield which will surely follow continuous grain growing. The experiment stations and some of the farmers are trying to solve the problems of restoring the humus and soil nitrogen and thus maintain the soil fertility. Experiments indicate that this may be accomplished by green manuring, rotation of crops, and deeper tillage; but it is a difficult matter to rotate crops in these exclusively grain raising areas, also the crops which are hardy 
and well adapted for green manuring have not yet been fully determined.

\section{INCREASING THE YIELD BY BETTER CULTURE}

Deep plowing compared with shallow plowing for wheat at the experiment station farm at Davis, California in forty trials gave an average increased yield of $37.4 \%$. At the San Joaquin valley station it was found that adding humus to the soil by green manuring with rye and vetch increased the average yield $244 \%$, compared with growing wheat after wheat, and the green manuring plot gave $62 \%$ greater yield than the bare summer fallow.

The relative yields were given as follows:*

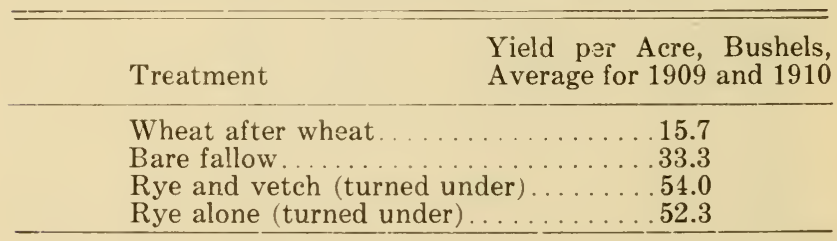

Professor Shaw concludes from these and other experiments that by means of deeper plowing and better culture methods, together with the growing of green manuring crops during the winter, the average acre yield of wheat in California may be doubled and at the same time the soil rendered more fertile. The use of commercial fertilizers did not as a rule give much benefit in the California experiments.

*California Experiment Station Bulletin No. 211. 
CONSERVATION OF SOIL MOISTURE

Scientific tillage to conserve the soil moisture and prepare a suitable seed and root bed is just as important in dry farming on the Pacific coast as on the western plains, and the same principles apply though the practice may vary somewhat.

Professor Geo. Severance of the Washington experiment station gives the following summary of methods for best dry farming practice:

" 1 . Keep up the supply of humus by chopping in all the straw and stubble available.

"2. Disk the stubble before the fall and winter rains begin, to absorb the precipitation as quickly and completely as possible.

" 3 . As soon as the soil is fit to work in spring work up two to four inches of loose, dry soil to hold moisture.

"4. Follow the plow as closely as possible with a subsurface packer.

"5. Harrow wheat in spring as soon after the soil is fit to work as the wheat is well rooted.

"Successful dry land tillage does not call so much for an increased amount of labor as for labor properly applied."

\section{VARIETIES TO GROW}

Club head wheat (Triticum sativum compactum), a sub-species of common wheat (Triticum sativum vulgare), is the type most largely grown in the Pacific coast states. This is a soft, white wheat not so valuable for milling as the wheat of the western plains, for it is necessary to blend 
it with hard wheat in milling in order to make good flour. The club wheat is grown because of its peculiar characteristics which make it suitable to the climatic conditions and to the harvesting methods commonly practiced. The climate being always dry at harvest time, the grain is left in the field until it is fully ripe, when it is harvested with the "combine" which harvests and threshes the wheat at a single operation. It is desirable therefore that the wheat should stand erect and not shatter. The Club Head is peculiar in this respect. It has a very compact spike without beards and a stiff, short straw. It is a rapidgrowing, early-maturing, erect-growing, non-shattering variety which is well adapted to the conditions. It is also hardy and a good yielder. Hence it has held its place as the most popular variety in spite of its poor milling quality.

In the Pacific coast states, wheat varieties are classed as "spreading" or "erect," referring to the early habit of growth of the plants. Certain varieties, largely grown in the central and western states, including nearly all the varieties of common wheat, spread out or stool for sometime before shooting. These varieties do not cover and shade the ground quickly and do not check weed growth.

The "erect" growing varieties of the club head type shoot up quickly and soon shade the soil and check weed growth, thus the wheat keeps ahead of the weeds. This is an important factor in wheat culture in the Pacific coast states, because of the foul, weedy condition of the wheat 
land caused by continuous cropping with grain which is harvested with the "combine" that scatters the weed seeds again. Hence the "spreading" varieties are not well adapted to the prevailing conditions and the general culture methods. The "spreading" varieties, such as Turkey Red, Crimean and Gold Coin are grown in limited area by irrigation, and such varieties may be suited to small farming where rotation of crops is practiced and where the wheat is harvested with the binder.

\section{WINTER OR SPRING WHEAT}

Winter wheat is grown almost exclusively in California. In Washington and Oregon the areas devoted to spring wheat and winter wheat are about equal. There seems to be no settled practice among the wheat growers, either as regards season of planting or variety grown. Thus winter wheat may be grown largely in one locality, while an adjacent locality, grows spring wheat. Club and blue stem are the principal spring varieties; winter fife and Turkey are the common winter varieties.

\section{WHEAT IMPROVEMENT}

A successful attempt has been made by the Washington experiment station to improve the varieties of wheat by crossing the soft, erect spring club varieties with the hard winter wheat of the Turkey type to secure hardy, erect winter varieties which shall be non-shattering and of better milling quality than the original club wheat. 
Several hydrids have thus been produced and fixed in type, which appear to give the desired results. Improved seed of these varieties is now being distributed to the farmers. Wheat improvement is also being brought about by the farmers through selection and grading of seed wheat.

\section{FARMING PRACTICE AND PROFITS}

The farming practice in use on the Pacific coast wheat farms, while not as thorough as it might be, is modern. Large machinery is used in tilling the soil. Engine plows are common. The harvesting is done with the combination harvester and thresher, which is propelled usually by thirty-two horses or by a traction engine. Binders are seldom used. The fertile soil producing large yields and the cheap and extensive methods of culture have made Pacific coast wheat farming very profitable. The cost of raising and market-

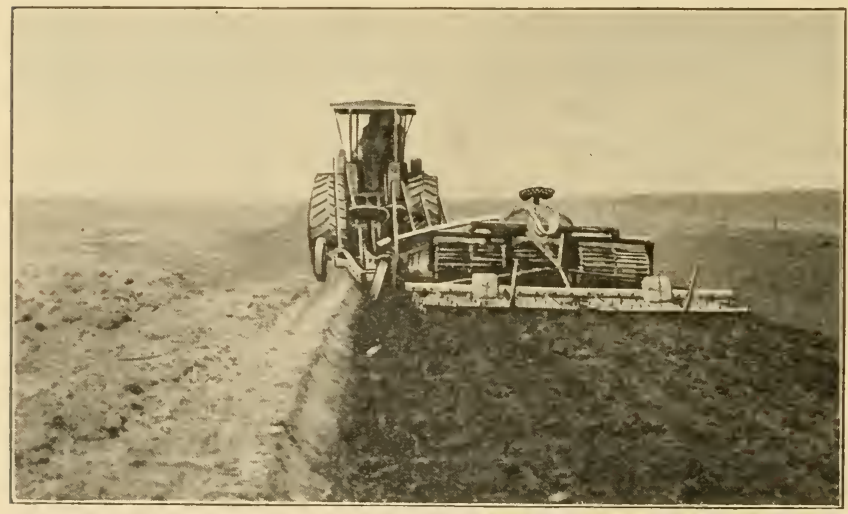

Fig. 31.-Large machinery is used in tilling the soil. 
ing wheat in the Palouse country is given as 26 to 40 cents per bushel, depending on the season, the method of farming and the distance from market. An even lower cost of production is reported for the Great Bend country and other wheat growing areas in Washington.

The average export price of wheat for the five years, 1906-1910, was eighty-five and one-half cents per bushel.* The average total wheat marketed by the four states per year for four years 1906 to 1909 was 49,493,041 bushels. The wheat is all handled in sacks. There are no grain elevators. In their place, ware houses are used and open platforms on which the grain is piled to await shipment.

In 1906 there were in operation in Oregon, Washington and Idaho, 241 flour mills with a combined output of 40,620 barrels of flour per day. Nearly two-thirds of the wheat produced is used for home consumption in the coast states or in the adjacent mountain states. The excess is exported largely to China and Japan. The total exports of wheat from Pacific ports in the United States averaged 29,000,000 bushels per year for five years, 1906 to 1910 .

*United States Bureau of Statistics Bulletin No. 89. 


\section{CHAPTER XI \\ WHEAT GROWING IN CANADA}

\section{A PART OF THE GREAT PLAIN}

"The western provinces of Canada are really one vast prairie which is included in the great plains region. Commencing some fifty miles east of Winnipeg this prairie extends westward over 800 miles to the foothills of the Rockies. It is really a series of three great plains, viz: (1) The Red River valley, a low, flat prairie, 800 feet above the sea, 7,000 square miles in area, extending from about the 96th to the 100th meridian, embracing the richest wheat lands of Manitoba. (2) The middle prairie extending from about the 100th to the 108th meridian, with an average elevation of 1,600 feet, about 105,000 square miles in area, one-half of which is fairly level open prairie and mostly good fertile soil. (3) The 'third steppe' extending from the 108th meridian to the Rockies, including Alberta and the western portion of Saskatchewan, average elevation 3,000 feet, area 134,000 square miles, topography more varied than the second plain but containing much fertile land.'

The prairie soils of western Canada are uniformly rich in plant food, especially in nitrogen. The large proportion of organic matter and humus gives these soils great moisture holding capacity and an agreeable physical condition favorable to the action of soil bacteria and rapid plant growth. Actual determinations by Prof. Frank ${ }^{*}$ Hand Book of Canada, 1897. 
T. Shutt, the government chemist at Ottawa, of samples of Red River valley soil gave an organic matter content exceeding $26 \%$ in black, heavy loam taken near Morris, and over $11 \%$ in black sandy loam taken at Brandon, Manitoba. Six other Red River valley samples gave an organic matter content varying from 11.44 to $21.54 \%$. In Saskatchewan twelve typical samples from various parts of the province gave an organic matter content varying from $5.54 \%$ in heavy clay loam near Maple Creek, to $14.23 \%$ in grayishblack loam near Tisdale. The other samples gave percentages varying from 10.20 to $13.93 \%$.

In Alberta the organic content of the soil is more variable but averages nearly as high as in Saskatchewan, the variation for nine typical samples being $5.89 \%$ in a dark-gray sandy loam at Lethbridge, to $17.83 \%$ in a black sandy loam at Lac la Nonne. The percentage of phosphoric acid, potash and lime averaged very high in all of the soils.*

Portions of Manitoba and Saskatchewan abound in lakes and ponds. Some areas are too flat and need drainage before the land can be farmed successfully. The soil is of glacial origin, and as previously stated it is usually very fertile and of great depth. It will not "wear out" with a few years of cropping, but there are other factors of uncertainty which may greatly reduce production in unfavorable seasons. The greatest of these are drouth and early frosts. The damage from early frosts may be in part overcome by planting early

*Department of Agriculture of Canada Bulletin No. 6. 


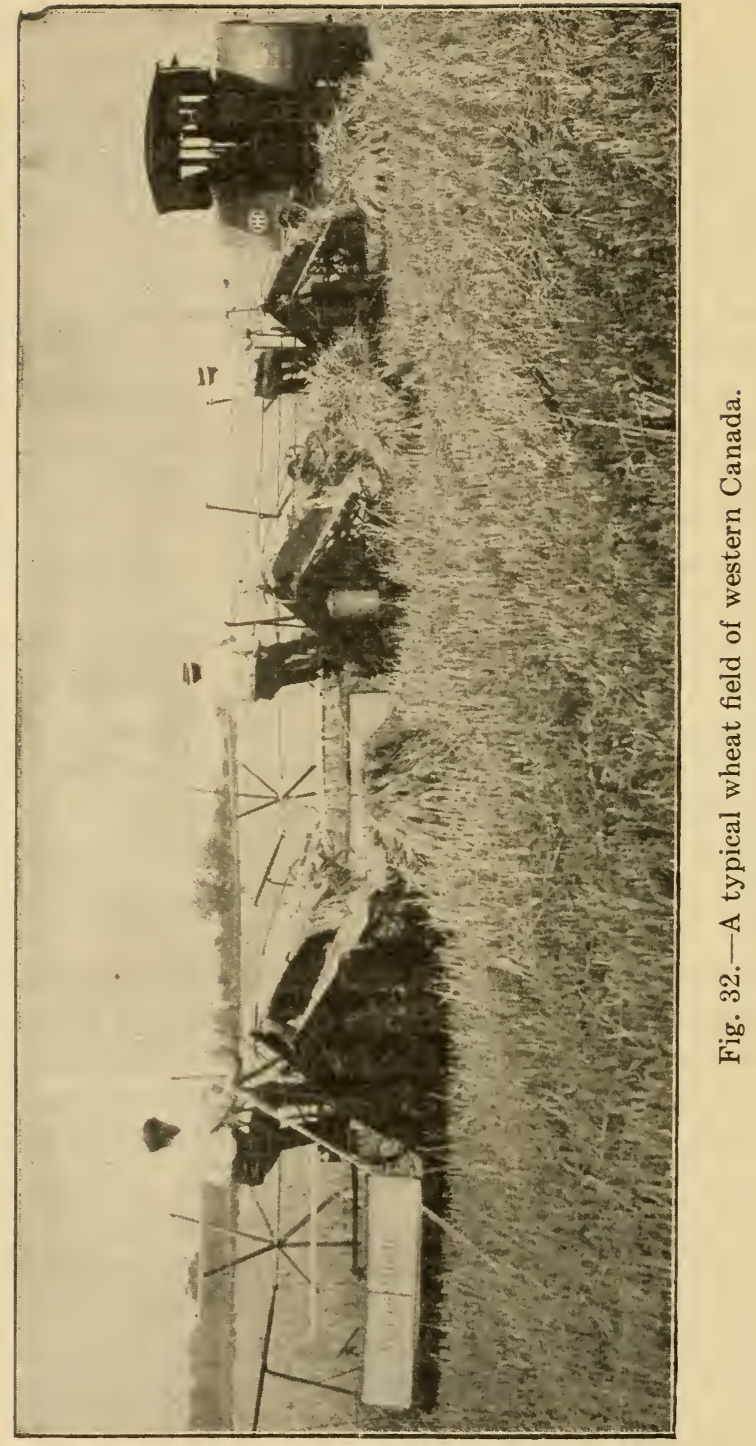


maturing varieties of wheat which have been bred and adapted to the climate and soil. The injurious effects of drouth may be largely prevented by clean summer fallowing and by practicing scientific methods of culture adapted to dry farming. Irrigation is practiced to some extent in Alberta, and limited areas may be irrigated in other provinces, but crops are largely grown by dry farming methods and this will continue since it will never be possible to irrigate any large part of the tillable lands of this vast region.

The Canadian west from the 100th meridian to the mountains is a "dry" country. The rainfall is variable, ranging from 9 to 30 inches for different years and different sections of the country. According to Stupart the total annual precipitation for Saskatchewan and Alberta averages less than fourteen inches and 17.34 inches is given as the average annual rainfall of Manitoba.

Other rainfall data is given as follows: Annual at Edmonton (13 years) 18.44 inches; at Regina, (7 years) 14.77 inches; at Prince Albert, 17.95 inches. Prince Albert, in Latitude $53^{\circ}-10^{\prime}$ is the farthest north point in the Saskatchewan valley where wheat is grown to any extent. The average annual rainfall at each of the several government experimental farms for four years, 1908-1911 is computed as follows:

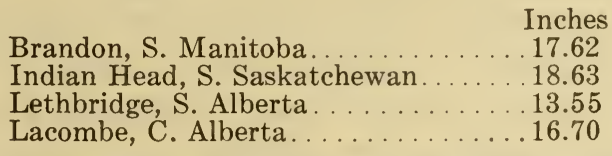

The total average rainfall for the six growing 
months, April 1 to October 1 for twenty-one years, at Indian Head is given as 12.93 inches-almost as great as the average rainfall at Ottawa for the same period. Thus while the annual rainfall is deficient, judging by eastern standards, there is this advantage - about $70 \%$ of the rainfall comes during the growing season. June and July are usually the months of greatest rainfall.

\section{WHEAT GROWING AREAS}

Prof. Charles E. Saunders, cerealist of the dominion experimental farms, has divided Canada into six chief wheat producing sections as follows:

1. The Maritime Provinces-Nova Scotia, Prince Edward Island, and New Brunswick-Not very much wheat is grown in this section-mostly spring sown-kernels plump but rather soft and starchy--best varieties-Preston, Huron, Stanley, Pringle's Champlain, Red Fife and Marquis.

2. Quebec and Northern Ontario: Small acreagemostly spring wheats-medium hard and good quality for milling-best varieties - Huron, Preston, Bishop, Marquis, Red Fife and White Fife.

3. Southern Ontario: 561,000 acres in 1912 mostly winter wheat-large, plump grain but soft and quite starchy-best varieties-Dawson's Golden Chaff (beardless), Turkey Red (bearded), Egyptian Amber and Tasmania Red.

4. Manitoba, Saskatchewan and Northern and Central Alberta: A large territory-large acreagemostly spring wheat-hard, glutinous kernelsexcellent quality for milling-best varietiesMarquis and Prelude (very early), Huron, Pres- 
ton, Pringle's Champlain, Bishop, Chelsea, Red Fife and White Fife.

5. Southern Alberta: The great winter wheat section of Canada; (some spring wheat grown) produces the best quality of hard red winter wheat, unexcelled for milling-yields large - best varieties-Turkey Red (bearded), Kharkof (bearded), and Ghirka (beardless). Seed of these varieties, secured from the Kansas experiment station in 1907 and 1908. The old "Alberta Red," still extensively grown, is a Turkey Red wheat but not so well bred as the new importations.

6. British Columbia: Small acreage as yetvariable climate-winter and spring varieties grown.

\section{VARIETIES}

In the classification of wheat growing areas given above the varieties recommended for sowing are mainly in the order of their highest yields. The oldest variety of wheat in Canada and the variety which is most widely grown and most highly esteemed is Red Fife. This wheat is remarkable for its productiveness, for its hard quality and high milling value, and for its power of adapting itself to varying conditions of soil and climate. Fife wheat was originated or discovered by an Ontario farmer, Mr. David Fife, after whom it is named. In 1842, Mr. Fife obtained a small sample of wheat from a friend in Glasgow, Scotland. It came in the spring, and not knowing whether it was a winter or spring variety, he planted some of it. It proved to be a winter wheat 
and never ripened, except three heads which apparently grew from a single seed. The grain from these heads was saved and planted the next season and the product was saved and planted again, and from it sprang the variety of wheat known all over Canada and the northern states as Red Fife or Scotch Fife.

\section{EARLY MATURING VARIETIES ESSENTIAL}

The Red Fife wheat had many points of excellence, but for growing in the more northern climates it had one serious fault-it was rather too late in maturing, and in seasons of early frosts the grain was likely to be injured and reduced in yield and value. This condition caused a demand on the part of the Canadian growers for an earlier ripening wheat. Dr. William Saunders, director of the dominion experimental farms, met this demand by importing early maturing varieties of wheat from northern Russia and India. These varieties proved to be inferior in quality and yield, but by crossing them with Red Fife, a number of new varieties have been produced which are earlier than the Red Fife, and in some cases nearly as good in quality and which produce large yields and are well adapted for growing in the western provinces. Several of these varieties such as Preston, Huron, Bishop and Stanley are well known throughout Canada and the northern states. More recent introductions are the Marquis and Prelude, which are proving to be the earliest and hardiest of the Saunders'varieties.

In thus producing these early hardy varieties 
Dr. Saunders has rendered a most valuable service to the wheat growers of the northwest, which not only makes wheat farming much more sure and profitable but it has allowed for the extension of wheat culture to more northern latitudes than was ever dreamed of before these hybrid wheats were introduced. It is reported that Ladoga wheat, one of the early Russian varieties, has been matured at Ft. Vermillion in latitude $58^{\circ}-30^{\prime}-600$ miles north of the MontanaAlberta boundary line, and 591 miles north of Winnipeg. A sample of sixty-two pound wheat was produced at Ft. Simpson, 818 miles north of Winnipeg.

\section{DURUM WHEAT}

Durum wheat is grown to a limited extent in Canada. It yields well in the eastern provinces and is particularly productive in the drier climates. It is hardier and more drouth resistant than ordinary wheat and often out-yields the common wheat where it matures well. The durum varieties are later in maturing than the earlier varieties of the common type. The durum wheat is unpopular with millers for flour making because of its extreme hardness and the yellowish color of the flour. It should be grown only for a special purpose or market and in considerable area so that it may be handled by separate elevators or in carload lots. Durum wheat usually sells at a less price than good milling wheat of similar grade and quality. Kubanka and Wild Goose are standard varieties and recommended for general planting. 


\section{WINTER WHEAT VARIETIES}

The winter wheat districts of Canada are quite distinct and limited in area. There are two principal areas: southern Ontario and southern Alberta. The climate of southern Ontario is quite humid and not favorable to producing a good quality of hard wheat. Soft or semi-hard wheats succeed best, such as Dawson's Golden Chaff, Gold Coin, Early Red Clawson, Red Velvet Chaff and Red Chief; but the Turkey and Kharkof varieties are also grown and produce a better quality of grain but give less yield as a rule than the other sorts. The climate of southern Alberta is quite dry and the winters are long, but the severe cold which prevails farther east in Manitoba and Saskatchewan is moderated in Alberta by the warm winds ("Chinook" winds) which blow over the mountains from the southwest.

The area which is most affected and which is best adapted for growing winter wheat lies along the base of the mountains and extends from the Montana line north to Calgary, a distance of 200 miles, and varies in width from 100 to 200 miles. In this favored area large yields of an excellent quality of hard red winter wheat are produced. This wheat has been given a market grade and is called "Alberta Red."

The original "Alberta Red" was simply Turkey wheat, the seed of which was imported from southern Nebraska in 1901. This stock was impure and mixed as the writer discovered during his visit to Alberta in 1907, where he was sent by the 
state of Kansas to study Alberta wheat with the purpose of importing seed wheat to Kansas. Because the wheat was mixed and of scrub breeding, I did not recommend the importation of "Alberta Red" seed wheat into Kansas notwithstanding its excellent quality, since our best Kansas varieties were superior in purity and breeding. I called the attention of W. H. Fairfield, superintendent of the southern Alberta experimental farm to this condition, and advised that he secure some of our Improved Kansas Seed Wheat, which he did.

The Kansas bred Turkey and Kharkof proved to be superior to the best "Alberta Red", producing from seven to ten bushels larger yields per acre in the first trials, thus demonstrating the importance of pure breeding. (See annual report of southern Alberta experimental farm for 1909.) Seed of these pure bred Kansas strains has been widely distributed in Alberta, so these wheats are now grown quite generally throughout the province.

\section{WORK OF PROFESSOR ZAVITZ}

Attention has already been called to the work of Dr. Saunders in producing earlier maturing varieties of wheat by hydridization and selection. This breeding work is being continued at several Canadian experiment stations. Doubtless, the durum wheats may be improved and made earlier by selection and breeding. This work is already being attempted by the agricultural college at Guelph, Ontario, which college under the direction 
of Prof. C. A. Zavitz has done a great amount of work in seed grading and seed selection. Professor Zavitz has shown by a large number of experiments with many varieties that the selection of the larger and heavier wheat kernels for seed has almost invariably given the largest yields. This work has established the importance of grading seed wheat and-has caused the farmers to fan and grade their seed wheat more carefully, which in the judgment of the writer, is one of the reasons for the increased acre-yield in Canada, noted for the past few seasons.

The grading of seed grain and the planting of the heavy seed is perhaps more necessary in western Canada than in the states because of the liability to injury of the grain by early frosts. The lighter, shrunken kernels are naturally the ones which are most likely to have been injured by frost. The improvement of seed wheat and other seed grain has also been greatly promoted by the Canadian Seed Growers Association which was organized in 1904. This association consists of farmers who desire to make a speciality of growing on their own farms, one or more varieties of "high class" seed under the expert direction of the government experiment station, for the purpose of increasing and distributing the better seed by sale to other growers.

The association had 200 operating members in 1910. A large amount of the best seed of all kinds of crops is grown and distributed in this way. The association holds annual meetings which are largely attended. 







\section{CHAPTER XII \\ CULTURE METHODS}

This chapter will relate largely to spring wheat, since it is the type most largely grown. The growing of wheat in the eastern provinces is comparatively limited and of relatively small importance. The grain is grown in rotation with other crops and in connection with the raising of livestock. The culture methods pursued are similar to those adapted to the eastern states.

The great wheat fields are in western Canada where there are millions of acres of new land available for wheat growing, not yet under cultivation. This great area is being rapidly settled. Millions of acres of prairie sod have been broken in the last ten years. Millions more will be broken in the next ten years. It is possible and profitable to use large machinery in the wheat farming of west Canada. Here on the wide prairies the big engine plows, the large harrows and disks, and the big twelve and fourteen foot drills can be used to the greatest advantage. The size of the machinery used should suit the size of the farm. The 160-acre farmer may use his sulky plow and two or three horse harrow, but farming on a large scale requires the use of large machinery and strong power. On the larger farms, four, six and eight horse teams and machinery to match is or should be the rule, and this method should bring the greatest profit. Many of the new settlers must necessarily begin in a small way because they are limited as to capital and 


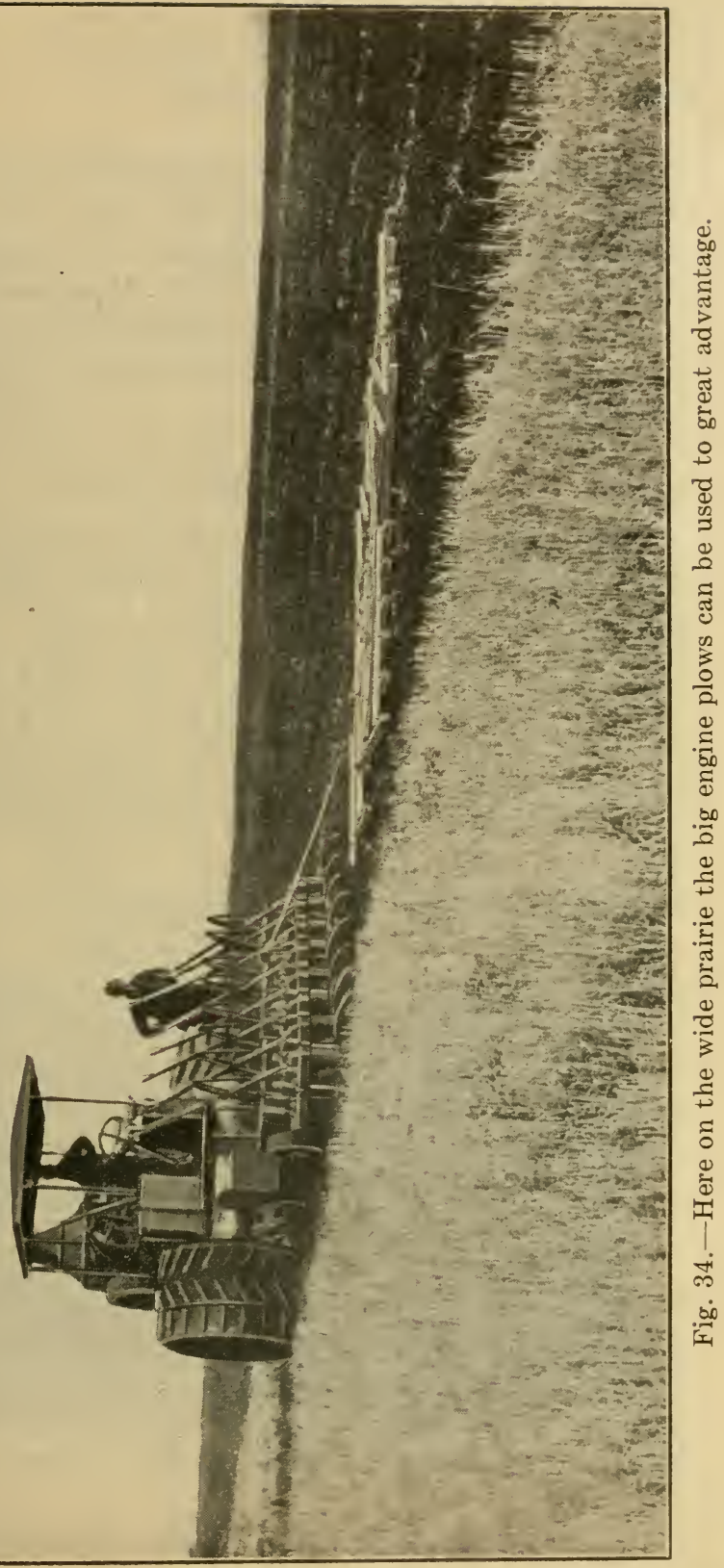


equipment. It is important, therefore, that they should begin right and make all their work count towards producing good crops. The success or failure of a new settler may often depend upon the method employed in the preparation of the land for the first crop. Hence, the question of breaking is of the utmost importance.

\section{BREAKING PRAIRIE SOD}

New settlers as a rule are anxious to sow every acre possible, regardless of how or when the breaking was done. Breaking done before July 1, while the soil is moist and in good plowing condition will usually produce a good crop of wheat, or other small grain the following season; but as a rule such land will fail to produce a profitable crop the second season after breaking because of the dry, undecayed and unfavorable physical condition of the soil. Sod broken after July 1st will usually remain dry and unrotted and the planting of late breaking, the first season after breaking, often results in crop failure and such land may remain in bad physical condition and unproductive for several seasons, if continuously cropped.

\section{BREAKING AND BACKSETTING}

Early shallow breaking and backsetting 2 to 4 inches deeper than the breaking is the best and most successful method of preparing new land for wheat on the western Canadian prairies. In some areas where the sod is thin and the soil is light, single early breaking 5 or 6 inches deep, 
followed by thorough disking may give good results.

Writing on this subject Prof. Angus Mackay, superintendent of the experimental farm for southern Saskatchewan, discusses "breaking and backsetting" as follows:

"Breaking and backsetting means the plowing of the prairie sod as shallow as possible before the June or early July rains are over, and in August or September, when the sod will have become thoroughly rotted by the rains and hot sun, plowing two or three inches deeper in the same direction and then harrowing to make a fine and firm seed bed. From land prepared in this way two good crops of wheat may be expected. The first crop will be heavy and the stubble, if cut high at harvest time, will retain sufficient snow to

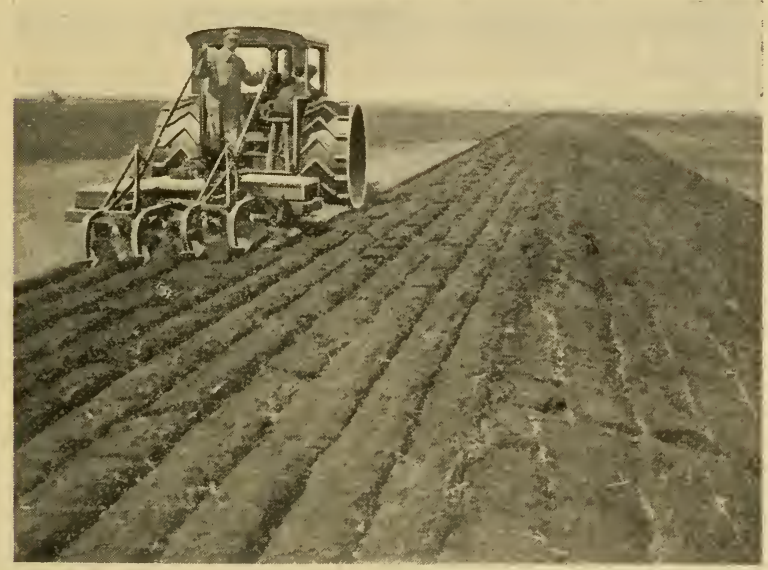

Fig. 35.-A first-class job of breaking. 
produce the moisture required, even in the driest spring, to germinate the seed for the next crop. The stubble-land can readily be burned on a day in the spring with a warm, steady wind and the seed may be sown with or without further cultivation. In a case where the grass roots have not been entirely killed by the backsetting, a shallow cultivation before seeding will be found advantageous but as a rule the harrowing of the land with a drag-harrow after seeding will be sufficient.

"The principal objection urged to "breaking and backsetting' is heavy work for the teams required in backsetting, but if the disking required to reduce deep-breaking and the other cultivation that must be done to obtain a second crop, be taken into consideration, it must be conceded that in the end 'breaking and backsetting' is the cheaper and better method.

"When two crops have been taken from new land it should be summer-fallowed."

In his "Methods of Preparing Soil for Grain Crops," Professor MacKay says:

"In view of the fact that every year brings to the northwest many new settlers who are unacquainted with the methods of breaking up and preparing new land for crops, a few suggestions with regard to this important work may not be amiss.

"In all sections where the sod is thick and tough, breaking and backsetting should be done; while in the districts where bluffs abound and the sod is thin, deep breaking is all that is necessary. "The former is generally applicable to the 
southern and western portions, and the latter to the northeastern part of Saskatchewan, where the land is more or less covered with bluffs."

"The sod should be turned over as thin as possible, (2 to 3 inches deep). When the breaking is completed (which should not be later than the second week in July), rolling will hasten the rotting process and permit backsetting to commence early in August.

"Backsetting is merely turning the sod back to its original place, and at the same time bringing up two or three inches of fresh soil to cover it. The plowing should be done in the same direction as the breaking and the same width of furrow turned. Two inches below the breaking is considered deep enough, but three to four inches will give better results.

"After backsetting, the soil cannot be made-too fine, and the use of a disk or Randall harrow to cut up every piece of unrotted sod, will complete the work."

\section{DEEP BREAKING}

"Deep breaking, which in some sections of the country is the only practicable way of preparing new land, and which is, unfortunately, done in some instances where 'breaking and backsetting' would give much more satisfactory results, consists in the turning over of the sod as deeply as possible, usually from four to five inches. When the sod has rotted, the top soil should be worked and made as fine as possible. The use of the harrow or disk will fill up all irregularities on the surface and make a fine, even seed-bed. 
"Whether the land is broken shallow or deep, it is necessary to have the work completed early, so as to take advantage of the rains which usually come in June or early in July. These rains cause the sod to rot, and without them, or if the plowing is done after they are over, the sod remains in the same condition as when turned, and no amount of work will make up for the loss."

\section{CLEAN SUMMER FALLOW}

While there are some objections to summer tilling land, such as soil drifting, overproduction of straw in wet seasons and waste of soil fertility, yet in a dry climate and a country given largely to grain raising, there does not seem to be any other practical method of keeping the land in productive condition.

The principal advantages of summer tilling are: The conservation of soil moisture, the eradication of weeds (the soil becomes foul with weeds by continuous grain cropping), the preparation of the land for wheat when other work is not pressing, the availability of summer tilled land for early spring seeding, and the ability to secure two good crops after the fallow with only a small amount of cultivation beside that required to complete the fallow.

\section{METHODS OF FALLOWING}

Different methods are practiced in the preparation of fallow land. When the plan has been to conserve the June and July rains and prevent the growth and seeding of weeds, success is almost 
sure; but when the plowing is done late and cultivation is neglected, failure is likely to result. Writing on methods of summer fallowing, Professor MacKay says in the report referred to above:

"The true worth of properly prepared fallows has been clearly demonstrated in past years in every district of Saskatchewan.

"The work of preparing land for crop by fallowing is carried on in so many ways in different parts of the country, that perhaps a few words on some of the methods employed may be of use to at least some of the new settlers.

"It has been observed in some parts of Saskatchewan that the land to be fallowed is not, as a rule, touched until the weeds are full grown and in many cases, bearing fully matured seed. It is then plowed.

"By this method, which no doubt saves work at the time, the very object of a summer-fallow is defeated. In the first place, moisture is not conserved because the land has been pumped dry by the heavy growth of weeds; and, secondly, instead of using the summer-fallow as a means of eradicating weeds, a foundation is laid for years of labor and expense by the myriads of foul seeds turned under.

"The endless fields of yellow-flowered weeds, generally Ball Mustard (Neslia paniculata), testify to the indifferent work done in many districts, and, while no weed is more easily eradicated by a good system of fallows, there is no weed that is more easily propagated or takes greater advantage of 
poor work on fallows or on fall or spring cultivation.

"Fallows that have been plowed for the first time after the first of July, and especially after July 15, have never given good results; and the plan too frequently followed of waiting till weeds are full grown, and often ripe, then plowing them under with the idea of enriching the soil, is a method that cannot be too earnestly condemned.

"In the first place, after the rains are over in June or early in July, as they usually are, no amount of work, whether deep or shallow plowing, or surface cultivation, can put moisture into the soil. The rain must fall on the first plowing and be conserved hy surface cultivation.

"Weeds, when allowed to attain their full growth, take from the soil, all the moisture put there by the June rains, and plowing under weeds with their seeds ripe or nearly so, is adding a thousand-fold to the myriads already in the soil, and does not materially enrich the land.

"Packers are without doubt most useful implements on the farm and where from any cause, the soil is loose, they should be used. They are, however, expensive implements and within the means of comparatively few of the new settlers. Fortunately, early plowing and frequent shallow cultivation may be depended upon to produce almost equally satisfactory results in the majority of cases.'

\section{CULTIVATION OF STUBBLE}

"When farmers summer-fallow one-third of their cultivated land each year, as they should, one-half of each year's crop will be on stubble. 
For wheat, the best preparation of this land is to burn the stubble on the first warm, windy day in the spring, and either cultivate shallow before seeding or give one or two strokes of the harrow after seeding, the object being to form a mulch to conserve whatever moisture may be in the soil, until the commencement of the June rains."

\section{FALL PLOWING}

"With regard to fall plowing it may be said that, as a rule, on account of short seasons and dry soil, very little work can possibly be done in the fall; but if the stubble-land is in a condition to plow and the stubble is not too long, that portion intended for oats and barley may be plowed, if time permits.

"It is, however, a mistake to turn over soil in a lumpy or dry condition, as nine times out of ten it will remain in the same state until May or June, with insufficient moisture to properly germinate the seed, and the crop will very likely be overtaken by frost."

The writer would suggest the discontinuing of stubble burning as advocated by Professor MacKay. Better disk thoroughly and leave stubble on the field.

Professor MacKay urges strongly that "early and thorough work on fallows is absolutely necessary to success." He has tested several methods and recommends as the best methods: Single deep plowing, seven to eight inches deep, before the last of June, followed by surface cultivation during the growing season sufficient to destroy 
weeds and conserve soil moisture. The next best method and perhaps the best and cheapest in some soils and some seasons is the "double plowing method": plowing deep (6 to 8 inches) before July 1, giving some surface cultivation during July and August and plowing rather shallow, (4 to 5 inches) immediately after harvest, after which the soil should receive such harrowing and packing as may be required to prepare a favorable seed bed.

The author would suggest also the testing of the listing method of preparing summer fallow discussed in these pages (see page 000) and which has been found so well adapted to dry farming conditions in the western states, viz., substitute listing in place of plowing in the "double plowing method."

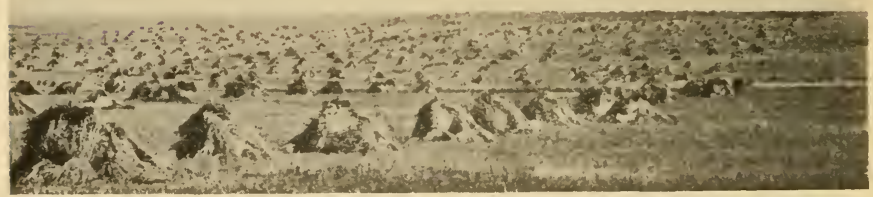

Fig. 36. - The far flung wheat fields of western Canada. 


\section{Chapter XIII \\ ROTATION OF CROPS}

Clover and alfalfa are grown successfully in eastern Canada and in southern Manitoba and Saskatchewan as are also the grasses-western rye grass, timothy and Bromus inermis. Alfalfa may be grown successfully also, in western Canada.

Wheat has given nearly as high yields at the southern Saskatchewan experimental farm when grown after field peas or sand vetch as when planted on summer fallow. Actual tests at the experimental farm at Indian Head, Saskatchewan, show that the soil which had been cropped twentytwo years with grains had lost nearly one-third of its total nitrogen, determined to a depth of eight inches, compared with the adjacent virgin prairie. Doubtless as the land becomes older the legume crops will be used more extensively in rotation with wheat, and the peas and vetch may be plowed under for green manure with good results if the plowing is not done too late. It is not advisable to plow the ground when very dry and cloddy. For some time, while the land is new, the occasional bare summer fallow will doubtless be the most practicable rotation and give the best results.

\section{OTHER POINTS ON SEEDING SPRING WHEAT}

It is important to seed wheat as early in the spring as the soil and season will permit, in order to insure maturing before frost. This will not 
usually admit of spring plowing but compels fall preparation of the soil and early spring disking of stubble land.

The best and usual method is to drill the grain, seeding quite shallow one and one-half to two and one-half inches deep. The best amount of seed to plant varies for the different areas and climates. Six pecks per acre is a common amount to sow in the eastern provinces, and four pecks per acre in the drier western provinces. Less seed is required on the drier lands. As little as two and three pecks per acre is sometimes seeded on summer fallow, or in a favorable seed bed.

CULTURE OF WINTER WHEAT

In his annual report for 1908 Prof. W. H. Fairfield, superintendent of the southern Alberta experimental farm, gives some suggestions and information regarding the culture of winter wheat as follows:

\section{PREPARATION OF THE LAND}

"If sod is to be used, it should be broken in May and June, while the soil is moist and before the rainy season is over. May breaking usually gives better results than June breaking. The sod should be rolled or flattened down as fast as it is broken to facilitate the rotting process. It is the custom to break three and one-half to four inches deep and prepare a seed bed by the use of a disk, drag harrow and float. The float should be followed immediately with the harrow, for evaporation takes place very rapidly from the land when 
the surface is left too smooth. If the floating is done just before seeding, the seed-drill will, of course, roughen the surface. A light harrowing immediately after seeding is advisable.

\section{BACKSETTING}

"Although it is not customary to backset in this district, it is a practice that cannot be too highly recommended. When backsetting is to be done, the sod should be broken as shallow as practicable and immediately rolled or flattened down by a weighted float. The earlier the breaking after the grass has started growth, the better will be the results. In the latter part of July or early in August the land is again plowed (with stubble bottom plows), about two to three inches deeper than it was broken. A seed bed can then often be prepared by the use of the harrow only, but a disk should be used if the condition of the ground requires it. Special attention should be called to the importance of harrowing each day's plowing at night before leaving the field. If an engine is used, the harrow should be attached to the plow, or if horses are used on a sulky or gang plow, one section of a harrow should be attached so that the land is harrowed as fast as it is turned. In fact, this practice of harrowing land immediately after it is plowed should always be followed. Too much stress cannot be laid on this point.

\section{TIME TO SOW}

"Although our results for this season would indicate that September 1, is the best date to sow, 
this is one of the questions that will require some further years experience and observation before a reliable opinion can be offered." (Later tests gave results favoring earlier seeding, August 15 to September 1, the best dates.)

\section{QUANTITY OF SEED TO SOW}

"This, as well as the proper time to sow, is a point about which we have not sufficient data at hand to draw very satisfactory conclusions. It is reasonably safe to assume that thin sowing will fill better in a dry season, while in a normal or wet season, medium to heavy seedings will fill equally well, besides producing a larger yield. It is not wise to go to extremes either way. Thirty to sixty pounds or forty-five to sixty pounds is probably the approximate amount of seed to sow per acre.

\section{TREATING FOR SMUT}

"Winter wheat should be treated for smut just as conscientiously as is spring grain. Either the formalin or bluestone method is satisfactory, providing that the work is done carefully. Very smutty grain should never be used for seed, for even when treated thoroughly, some smut is apt to appear in the resulting crop.'

It is hardly possible to follow winter wheat with winter wheat in Alberta since the harvest occurs early in August, only a week or two before the next crop should be seeded. It is almost necessary, therefore, to seed on summer fallow, unless the crop is sown on new breaking as heretofore dis- 
cussed. This method insures a good yield almost every season.

\section{HARVEST AND THRESHING}

The wheat harvest season in Canada is necessarily late, beginning the latter part of July in the southern latitudes and continuing into September in the more northern sections. Light frosts often occur in August, but heavy damaging frosts do not usually occur before early September. The methods of harvesting are the same as in the middle and western states. Both the header and the binder are used, the binder being used exclusively in the eastern provinces.

Threshing is accomplished by large steam driven outfits, and continues late into the fall. In the west straw is of little value and is usually burned to get it out of the way.

The grain is handled in bulk through elevators the same as in the western states. Most of the surplus wheat and flour are shipped to Great Britain. The total wheat export of Canada in 1911 was $60,474,020$ bushels of wheat and 3,542,112 barrels of flour (equivalent to 15,939,558 bushels of wheat, (computing four and one-half bushels to one barrel of flour) or a total export of $76,413,578$ bushels of wheat. This is nearly equal to the total wheat export of the United States which was only 83,329,750 bushels in 1911 (including 11,258,030 barrels of flour).

The shipping facilities are good considering the vastness and newness of the country. Western Canada is well supplied with railroads and the 
storage capacity at the many railroad stations has kept pace with the rapid increase in wheat growing. Western Canada has three trunk lines of railroad and these railroads have built thousands of miles of branch lines and new roads are still being built. The Canadian Northern will soon complete a new line from northern Saskatchewan to Ft. Churchill on Hudson's Bay with the purpose of opening a new water route to Europe. The advantage of this Hudson's Bay route can not be over-estimated. Ft. Churchill to Liverpool is the same distance as New York to Liverpool.

The thousands of miles of railroads and the ever improving shipping facilities, the vast areas of cheap lands, the remarkably fertile soil, the progressive class of settlers who have taken up these lands, (largely Americans from Iowa and Minnesota and farmers from eastern Canada) and the increasing number of new settlers who continue to come each year give a very promising outlook for the development of the wheat growing industry of the great Canadian Northwest. This development will do much towards relieving the situation as regards the decreasing world's supply of food over which some economists have worried during the last few years. 


\section{Chapter XIV \\ SEEDING MACHINERY}

There are two general methods of seeding wheat, broadcasting and drilling. Broadcasting is nature's method of distributing seed and was the first method employed by man. The seed was simply scattered by hand. Hand seeding is still practiced in sowing grass and clover, but the hand seeding of grain is largely a lost art in this country, since machinery for this purpose makes the work much easier and more rapid. In parts of Russia and in other eastern countries, hand seeding is still employed.

Drilling in shallow furrows made by a shoe or disk is now recognized as the best method of sowing wheat and most other small grains. Drilling requires less seed than broadcasting because the seed is more evenly distributed and more uniformly covered. It is possible to deposit the seed in the firm, moist soil which with the even depth of planting results in a more rapid, stronger and more uniform germination. Because of the planting in furrows, drilling also, to some extent, decreases the danger of injury by drouth, winter killing and soil drifting.

\section{BROADCAST SEEDING MACHINES}

Broadcast seeding machines are of two general classes:

1. The broadcast sowers which distribute the grain by means of a rotating seed plate in the bottom of a hopper which feeds the grain to the 
plate at a uniform rate, from which it is thrown by the rotating force in every direction. The best machine of this type is the endgate seeder which operates at the rear end of a wagon box and is driven by a gear attached to the wagon wheels. Two men and one team can sow fifty to seventy-five acres per day with this machine.

2. The broadcast wheel seeder which is really a long hopper, containing many spouts or seed cups supported on wheels. In the early forms, the grain was simply drawn through the spouts or holes in the hopper by gravity and distributed more or less uniformly over the ground beneath. In the modern seeder the turning wheels drive a force feed which carries the grain up from the bottom of each seed cup and drops it regularly onto a disk or inverted pan from which it is spread quite uniformly in all directions by the force of gravity.

Many seeders are provided with shovels which drag through the soil thus covering the seed. The wheel seeder is probably used more generally today than the broadcast sower, but in the seeding of wheat it has been largely succeeded by the drill.

\section{DRILLING MACHINES}

Contrary to the usual understanding, the grain drill is a very old implement. The first historical mention of grain seeders is by the historian Ardry, who states that the Assyrians used grain drills many centuries before Christ.

In 1730, Jethro Tull introduced the grain drill into England. The first patent was granted on a 
grain seeding machine in the United States in 1799. The rotary seeder was introduced in 1856, the grain drill in 1874.

The grain drill differs from the broadcast seeder, (which feeds the seed onto a spreading pan or oval disk which causes it to scatter broadcast over the ground, when it is covered by the shovels or hoes which follow in the rear of the machine), in that the seed falls into a grain tube and is carried in a steady stream to the bottom of the furrow made by the shoe or disk, where it is covered by the drag chain or press wheels which follow the shoe or disk furrow openers. Thus the grain is planted in straight rows or drills in the firm moist soil on the floor of the small furrows and evenly and regularly covered with mellow or pressed soil as may be desired.

\section{DEVELOPMENT OF FORCE FEED}

The development of the grain drill has been rapid. The old gravity feed has been replaced by the force feed. The original method was to allow the seed to run out through a hole in the bottom of the seed cup. An agitator kept the grain stirred so that it might feed regularly through the openings which could be regulated in size by moving a slide. It was not possible to sow very evenly with such a drill since the jar of the machine as the wheels passed over clods or obstructions caused the seed to run irregularly.

The force feed raises the grain above the bottom of the seed cups and forces it out at a regular rate by means of grooved wheels or grain pinions 
which are driven by a small revolving shaft connected with the main shaft by sprocket gears or chains. The rate of seeding is regulated by increasing or decreasing the width of the opening through which the grain is forced or by changing the speed of the grain pinions by a gear adjustment.

The modern force feed drill does its work very accurately, and a good drill may be adjusted and set to sow very evenly a definite amount of grain per acre.

\section{THREE FORMS OF GRAIN DRILLS}

The modern wheat drill is made in three general forms: 1. Hoe drills. 2. Shoe drills. 3. Disk drills. Disk drills are divided into two general classes: Single disk drills and double disk drills. The shoe and disk drills may have press wheels attached in the rear to cover and press the soil over the seed, or more commonly short chains are used which drag the loose earth into the furrows and thus cover the seed.

The hoe drills, which were the first type manufactured, open the furrow with a shovel or point which is dragged through the soil and forced down by pressure springs. These drills give heavy draft and tend to gather trash and clog.

The shoe drill is an advantage over the hoe drill in that the shovel is replaced by a sharpened runner or shoe which cuts into the soil, opening a $\mathrm{V}$ shaped furrow. The shoe drill runs lighter and tends to draw over the rubbish to some extent and does not gather trash as badly as the hoe 
drill. It is a good drill in a clean well prepared seed bed.

The disk drill has the advantage of the shoe drill as a trash rider, since in place of the shoe a revolving disk rolls through the soil, riding over or cutting under trash and opening a neat furrow in which the seed is deposited. The disk drill draws a little lighter than the shoe drill and has a special advantage in trashy land or hard ground. The double disk does nice work in well prepared land which is not too hard or trashy, but the single disk is superior in hard or trashy ground.

As a general drill for use on all kinds of ground the writer prefers a good single disk drill, but the double disk drill and shoe drill have some advantages for shallow seeding, as in sowing alfalfa or grasses, since their depth of seeding may be better controlled.

Drills are manufactured which make the furrows $5,6,7$ and 8 inches apart. When the shoes or disks are seven to eight inches apart the machine is less likely to clog. The standard drills more commonly used make furrows six or seven inches apart.

Drills and seeders are made in standard widths varying from eight to fourteen feet. Single drills, three feet wide, for sowing wheat between the rows of corn are also in common use. In the Red River valley four and six horse machines having a width of eleven or twelve feet are used. One man with a good team can sow thirty acres per day with one of these large machines.

Grain drills may be purchased with grass seeder 
attachments, when the grass and clover seed may be sown at the same time the grain is seeded. The grass seeder usually scatters the seed broadcast either before or after the opening of the furrows, as preferred. The writer prefers an attachment by which the grass seed may be run through a tube into the drill furrow, thus alfalfa or grasses may be seeded alone in drill rows and the depth of seeding regulated.

Modern drills may also be provided with attachments for distributing fertilizers at the same time that the grain is sown. There are several different styles used and most of them do satisfactory work. The writer rather prefers to have a separate machine for distributing fertilizers. A lime spreader will do the work and is needed on many farms on which the soil is becoming "worn" and "sour."

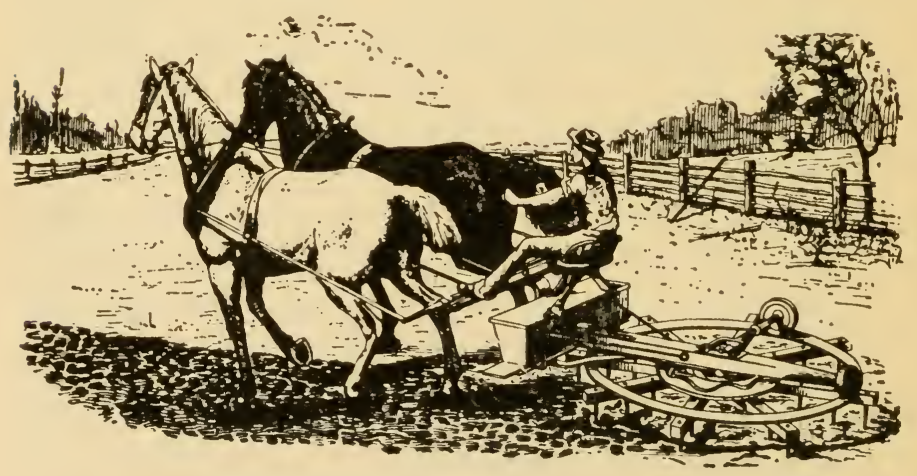

A seider f'atented in 1878 
APPENDIX 



\section{I}

\section{INDIVIDUAL PRACTICES}

Seager Wheeler of Rosthern, Saskatchewan, who received the prize of $\$ 1,000$ at the land show in New York for the best bushel of wheat, giving his experience under Canadian conditions, says: "At the time of taking up the matter of seed selection I was growing the ordinary Preston wheat which was not fixed to a distinct type. This wheat at the time was a mixture of reddish and white chaff, also was straw colored and red. The first year I eliminated the white chaff variety. This fixed the color of the chaff but I still had to separate the red grain from the yellow in order to fix the color. It is not necessary now to do this work as the beginner can secure pure-bred seed to start with.

"All this work in selecting by hand would be of little benefit if the seed bed were neglected. It would be folly to sow good seed on a poorly worked or weedy seed bed. Therefore, it is highly important to have the seed bed in good condition. The two together make for improvement in both quality and yield. Such seed should be grown on breaking, summer fallow, or root land.

"I will now outline my method of preparing summer fallow. The land should be disked or shallow plowed in the fall, the season before. I prefer the shallow plowing - at a depth of two inches, followed by packing to start weed growth in the spring. In the spring if possible, it should be given a stroke of the harrows to break up the 
crust that will form after the snow is gone. As soon as possible after seeding time it should be plowed deep, care being taken that the furrow is well turned down. I use a home-made roller behind my gang plow. This packs down the furrow and holds the moisture. I would advise every farmer to put on a pulverizer attachment behind the plow. By this operation my plowing is rolled immediately to conserve the moisture. The plow is followed by a surface packer to pack it down more. After it is packed I use a plank drag similar to what is called the King Drag or road drag. This is made with two two by eight planks nine feet long, placed on edge three feet apart, the ends overlapping one foot. Pieces two by six are mortised in to hold the planks in place. On these boards are nailed for the driver to stand on. It is operated at a slight angle. The driver should stand on it to do good work, and by shifting his position on the drag the angle may be altered to suit. The drag is operated up the right hand side of the field, crossing at the end and following down by the first dead furrow, doing the field in sections to avoid waste of time crossing the ends. The reason for using the drag is that I want to level up the field and put the surface in a uniform condition. Should a rain come shortly after, it is surprising to see how weeds will germinate. Rain penetrates readily when land is in this condition. "As soon as possible after a rain, while the soil is moist (not wet not dry) it should be harrowed. If disking is necessary during the summer the drag (plank) will put it in uniform condition again, 


\section{A P P E N D I X}

173

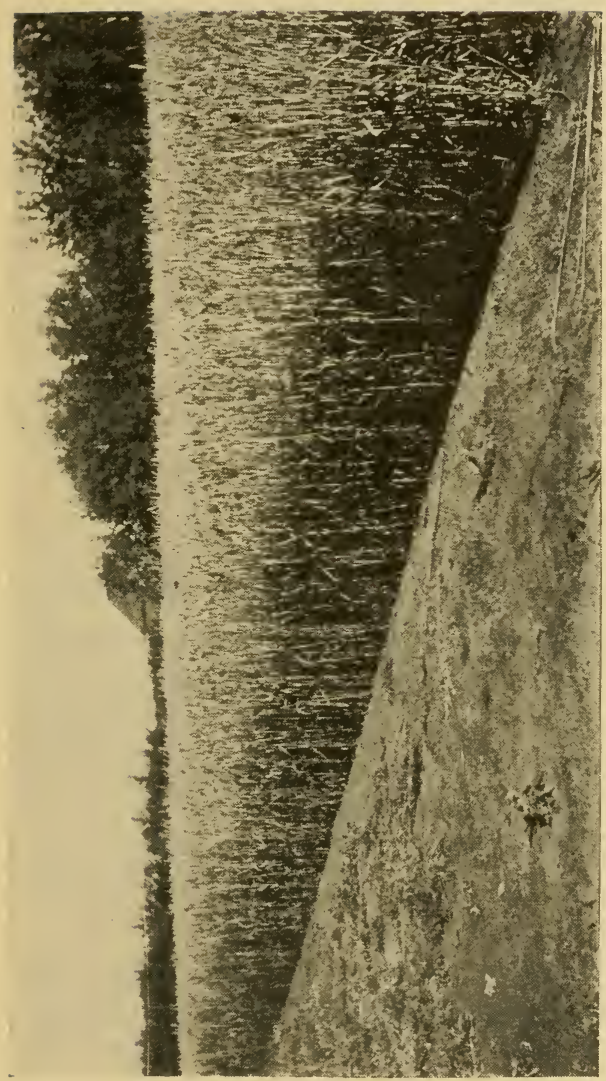

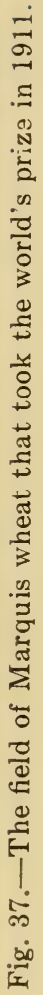


levelling any ridges. Cultivation should be kept up to kill weeds and conserve moisture. The next spring you will have a firm seed bed in a uniform condition. When the seeder goes on a field like this you will notice the benefit of the plank dragging. The seed bed is uniform and the drill plants the seeds at a uniform depth. The surface packer follows the drill, not for the purpose of packing the root bed but to pack the moist soil around the seed to hasten germination. This is followed by the harrows. After the grain is up four to six inches I harrow to cultivate and kill any weeds. The harrows I use are home-made for the purpose. They are light and do good work. The object is to keep the grain growing by cultivating it.

"I also use the plank drag on breaking as well as on fall and spring plowing. In plowing in the spring for a crop I follow the same method, using the packer after the plow. Then comes the drag, then the seeder followed by the packer, and then the harrows. This insures getting the seed in a firm seed bed while moist. Cultivation can be done after it is seeded. Fall plowing also is treated according to the same method of preparing the seed bed.

"In my opinion it is a mistake to seed fall plowing early in the spring. It should be given a stroke of the harrows to conserve moisture and allow weeds to germinate. It can be sown later on, as fall plowing generally matures a crop faster than spring plowing, breaking or summer fallow. I would sow breaking first and summer fallow 
next, and then do some spring plowing before sowing fall plowing. Many farmers make the mistake of sowing fall plowing first and then wonder why the crop is light and weedy.

"I do not claim that my method is the best that can be followed but the principle remains, that whatever method is adopted I am a firm believer in the plank drag before the seeder.

"The most important point to insure a good quality of grain and increased yield is to sow good seed in a good seed bed and have uniformity. All these three go hand-in-hand-you cannot separate them.

"By good seed I mean seed of a pure variety, well cleaned and free from broken grains, small grains, light grains, or immature grains, as well as weed seeds, so that the result is uniform seed. A good seed bed is one that is well prepared, as outlined above, giving a uniform depth, insuring uniform germination, uniform growth, uniform heading out, uniform ripening, uniform grain for the binder to operate on, uniform sheaves, less waste in cutting, a uniform surface for the binder to run on and make nicely bound sheaves. You also have uniform grain of a uniform quality. Besides, when the plow goes on the land again it runs more smoothly and turns a furrow at a uniform depth. Therefore, uniformity plays a most important part, no matter what methods are adopted.

"I wish again to lay stress on the use of the plank drag. I would not care to farm without it. If I could follow out my own inclination I would 
follow the plow with a subsurface packer to pack down the furrow slice, using the surface packer after the seeder, principally to pack the soil around the seed. Years ago I used to harrow behind the plow in the spring, and harrow and harrow, and then wonder why the stools would turn yellow and die down in a hot spell in July. It also seemed strange that some of the grain would germinate at once and some come up later after the first rain, resulting in uneven growth. My object now is to sow the seed while the seed bed is moist and cultivate afterward. I know of no better method than that which I have outlined. At least it has always given good results with me. When I find a better way I will change my system of farming.

"I have seen men who would go out in the spring and plow after a fall of snow while the snow lay on the ground. After the grain was up I have walked over their fields sinking ankle deep in dry dust. Such crops as these suffer in every dry spell.

"Many farmers make great blunders in regard to depth of burying their seed. With a seed bed prepared, as I have outlined and on soil such as we have to deal with, I have concluded that one to one and a half inches is the proper depth for wheat on summer fallow as well as on thoroughly prepared new breaking or fall plowing. For spring plowing the best depth is about two inches. The important consideration is the moisture line. Plant the seed just below the moisture line and then pack to insure quick germination. 
"The prize wheat was sown on April 21 and cut on August 28. After sowing it was packed. When the grain was up four to six inches high it was harrowed by the light harrows for the purpose of cultivation. The growth was vigorous and strong. I may say that I always harrow growing grain whenever possible. The main thing is to have a solid seed bed and uniform surface. I run the harrows with the drill rows on a hot, dry day to kill weeds. Such harrowing does not injure the grain. On a loose seed bed, however, harrows might smother some grain and also pull some out. It is giving attention to small details that counts whether we are growing grain for market, for seed, or for exhibition purposes - attention to every detail in preparing the seed and the seed bed, treatment for smut and in the cleaning process.

"Every farmer should be particular to sow only the best seed; he should take care that the seeder is cleaned before putting in another variety or another kind of grain. Clean off the binder to every straw when entering on a field of grain of another variety. Such time cannot be counted as lost, but rather as gained." 


\section{II}

WHEAT THAT WON THE WORLD'S PRIZE IN 1913

The wheat that won the world's prize at the Dry Farming Congress held at Tulsa, Oklahoma in 1913 was grown by Paul Gerlach, Allan, Saskatchewan. In addition to the various qualities that gave this wheat the prize it was remarkable in that it broke the world's record in weight, weighing seventy-one pounds to the bushel. A statement of how this wheat was grown including the steps taken in the preparation of the soil as well as those in breeding up the seed follows. "I am asked to what I attribute my success in growing the wheat that took the world's prize at the Tulsa Dry Farming Congress. Replying I should say to good seed and to feeding the plants well. How the seed was originally secured, later improved and finally how the soil was tilled shall relate.

"Marquis is a hybrid, having been produced by crossing Red Fife with Red Hard Calcutta, and the product carefully selected, under the guidance of Dr. Saunders at Ottawa. The advantage Marquis possesses over Red Fife, is about eight to ten days earlier maturity, and about six bushels more per acre. The straw is very strong, of medium length and the bald heads well chaffed. As to milling value it is fully equal to Red Fife. Now that Marquis has thrice in succession won the World's Championship, there can be no doubt as to its superiority. 
"I came from Detroit, Michigan, seven years ago, and located on a homestead eight miles south of Allan. I learned after a few years farming, that there was some danger of a possible early frost damaging the wheat, particularly if grown on heavy soil and sown late. I noticed an article in a farm journal telling of the qualities of Marquis. I sent for five pounds, the quantity allowed each farmer, and persuaded a few friends to secure an equal amount and pass the same on to me. In that manner I received fifteen pounds, which I sowed on breaking. The product I threshed with a flail to assure purity. The next year I sowed the wheat on summer fallow, and during the growing season I culled out bearded heads, other grains, also any stray noxious weeds. This plan I followed each succeeding year, using great care in threshing to avoid mixing.

"My 1911 crop was particularly fine, and a sample shown at the Provincial Seed Fair, secured the championship, scoring ninety-nine points, weighing sixty-six and one-half pounds, ranking highest in purity and second in milling value in its class.

"The next year my exhibit at the same Fair was awarded second prize, scoring $94 \frac{1}{2}$ points, ranking first in purity and milling value.

\section{METHOD OF SEED SELECTION}

"After winning the Provincial Championship, I wrote to Dr. Saunders asking him for a small amount of a superior strain of Marquis, if he had one, as I wished to get the best available. I also 
told him what I had done and the result. He advised me to select from my own, as there was no better to be obtained. I then selected a bushel of the choicest kernels, which were sown in our garden. After the plants were headed out, I carefully culled out all plants not to my fancy. I did this at least a dozen times. The product of this plot, I recleaned and sowed on summertilled soil and again the culling process was resorted to. I can assure you I felt a thrill of joy as $I$ rode the binder while cutting this field, the straw had just a tinge of green and the grains were quite firm. I had sown a bushel to the acre, and the yield was thirty-seven bushels.

"It became evident that I could not get a machine to thresh my crop very early, so I hauled several loads of sheaves to the barn, the remainder was left in the stook or stack. It was the wheat stored in the barn that won at Tulsa, Oklahoma, weighing slightly over seventy-one pounds to the bushel, which I understand is a world's record.

"The other wheat was threshed late, causing a loss of several bushels per acre and of a somewhat bleached sample, which, however, would not impair its value for seed.

"I am still further improving my wheat by hand selection. While culling over the small field above mentioned, I noticed some plants showing a superiority over the others, the heads were nearly square, filled from end to end with large kernels. I spent three days selecting a sack full of these heads which I threshed in a bag to 
avoid any possible mixture. Last spring I sowed this seed in the garden and after the plants were headed, I weeded out any heads not true to the type I desired. As soon as the grain was ripe I selected a sack full of heads conforming to my ideal. These will be threshed and sown next year. I shall continue improving my wheat if such is possible.

\section{FOLLOW THE CAMPBELL SYSTEM}

"Now as to how I till the soil. My main effort is to conserve moisture, in this I try to follow the Campbell system of soil culture, (Campbell Soil Culture Co., Lincoln, Nebraska). Our soil is a moderately heavy chocolate clay loam and works up nicely if done at the proper time. In preparing summer fallow, I prefer starting the year before, by following the binder with a disk harrow, disking the stubble as soon as the grain is cut, keeping far enough away from the standing grain to permit the large wheel of the binder to travel on solid ground. As long as the straw is standing it acts as a blanket on the earth preventing evaporation to a large extent. As soon as the straw is removed the protection is gone and sun and wind soon dry out the surface. By disking as stated, I gain in various ways. First, I break up the capillarity of the surface soil to prevent the loss of moisture through evaporation. Second, the soil is in splendid shape to receive a rain and permit the water to enter the soil quickly and to escape through evaporation very slowly. Third, by thoroughly mixing stubble, weeds, roots, 
straw, etc., with the soil, the surface two inches or more, when turned under with a plow, will produce a fine root bed, whereas if all this material were left, as is often the case on most farms, without disking, the dry earth, stubble, etc., would be turned under all in one mass, causing an open dry, condition which must be an inhospitable home for the roots of plants. Water from below the depth of the furrow cannot reach the roots, neither can the roots reach the water. As soon as the moisture in the surface soil is exhausted the plants suffer. Fourth, by covering weed seeds at this time, many will be started to grow and freeze during the winter. Those that do not die, or those that fail to grow during the autumn, will grow early the next spring and are then cared for.

"I do not recommend burning the stubble, unless there is too much of it to disk under. In cases where a large amount of stubble is present and many noxious weeds as well, I would certainly resort to burning. I desire to put back into the land as much humus as I can. By destroying the stubble by fire, you do not improve your soil.

\section{HOW SUMMER TILLING IS DONE}

"After seeding is finished in the spring, I disk the land to be summer tilled. This will kill many weeds and cause others to grow; it also opens the soil to receive and retain the rains. As soon as the weeds have started growing, I begin plowing. I turn a furrow of about six inches, and shall go a little deeper each year until a sufficient depth 


\section{A P P E N D I X}

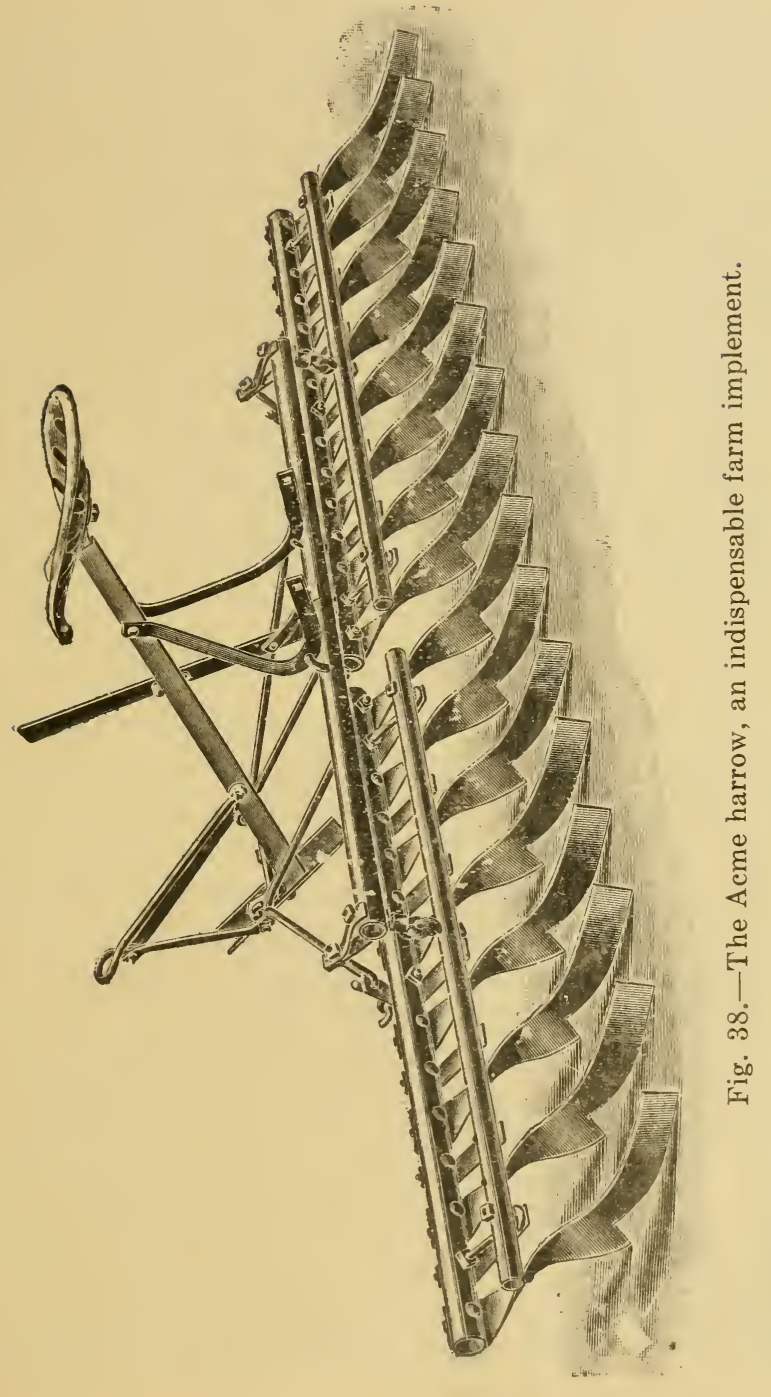


is reached. I follow with the subsurface packer every half day. This I consider important as the soil is then in splendid shape to be packed, it is soft and pliable, air spaces are crowded out, capillarity is re-established and plant food is being manufactured. I harrow each day's plowing before night to conserve what moisture I have. After each rain that settles the mulch sufficiently to permit the capillary movement of the water to the surface, I go over the field with the acme harrow, this kills weeds and produces a perfect mulch. I desire to keep the soil as black as possible during the season, if weeds are allowed to yrow they take away the moisture intended for the wheat.

\section{LIGHT SEEDING AND HARROWING}

"On the field that produced the wheat shown at Tulsa, I sowed one bushel per acre, to a depth of three inches, well into the moist soil and just below the mulch. I do not recommend that amount on all soils or under all conditions. The seed was treated with formalin by means of an immersion bath. After drilling, the ground was packed with a corrugated packer, this pressed the soil particles close to the grain, bringing moisture to them, resulting in an even germination. By firming the surface, the moisture was brought from the lower, into the upper soil, causing any weed seeds that were near the surface to grow and these were harrowed out just as the wheat emerged above the ground. I use a lever harrow with the teeth set at an angle of about forty-five 
degrees. When the wheat had attained a height of about four inches, a rain fell which settled the mulch, and the day following we again harrowed the field, getting rid of many weeds and reestablishing the mulch to conserve moisture and allow a more perfect circulation of air in the soil. There was nothing further done until the heads were visible. I then hired a man and it became his duty to cull out any plants not true to type, other grains, or noxious weeds, in fact, I do this with all my fields.

"I am convinced that if farmers understood the controlling of moisture and the manufacture of plant food better, there would be less crop failures. Let me draw a simile: Suppose I were to live entirely on broth. I would place a vessel containing water over a fire, and in it a quantity of meat, preferably cut into smaller pieces. The chemical change now taking place in the water would be caused by heat. The heated water extracts the nutriment from the meat. The longer the extracting process goes on, the stronger becomes the broth, the less of it I would require to satisfy my bodily need. A small amount of the concentrated broth would be as nourishing as a large amount of the weaker.

"Now, how is that simile applied to soil culture and plant growth? If I mix the stubble, straw, manure and so forth with the surface soil, then turn it into the bottom of the furrow and pack it down well, I crowd out all air spaces and bring moisture to the material I turned under, which causes it to decay-forming plant food. By 
harrowing after each rain of any consequence I prevent the escape of moisture. By plowing early in the season (for summer fallow) I have my food factory at work a long time, and under the effect of the heat caused by the summer's sun, a large amount of plant food is extracted from the material plowed down or from the soil particles and held in soluble form, which is the only form in which plants can partake of the food. The richer the food, the less each plant requires.

"I tilled the soil which produced the prize wheat as nearly as possible along the lines I have indicated, and by sowing only a bushel to the acre, did not crowd the plants, but each had a full supply of rich food, the result was, the world's best and heaviest wheat, over seventy-one pounds to the bushel. The 1911 Prize Wheat weighed sixty-five, the 1912, sixty-four.

"I was greatly pleased at my wheat winning, but I have greater pride in the knowledge that the seed that produced the wheat has been brought to such a state of perfection on our own farm, after years of painstaking effort, under the joint care of my wife and myself. I give full credit to her for her share." 


\section{HOW TO RUN A BINDER}

The best machine ever made is worthless in the hands of the man who has not sufficient knowledge of its mechanism to adjust it properly and to care for and repair it. The following advice on how to run a binder by Persey Wastle and published in the SCIENTIFIC FARMER is so full of practical hints that it is reproduced verbatim.

It seems that there is a dearth of advice in our agricultural papers concerning the operating of farm machinery, excepting probably, the gasoline engine. We read a great deal of how to take care of our implements when not working, such as oiling them and putting them away under cover, all of which is very important, but I think a few pointers on how to run them when in the field would not come amiss.

I wish to deal with the self binder, one of the most ingenious, and also one of the greatest labor saving machines in existence. We will suppose the grain is nearly ripe; so we will pull the binder out of the shed, where it has been carefully housed since last harvest, though this is rarely the case in the west. I have generally noticed them, or at least all one could see of them for weeds, standing in the corners of the fields, where they were left the year before.

The first thing to do is to go all over the binder with a wire pick, and clean the oil holes. It is advisable while doing this to notice if there are any broken parts, so they can be sent to town for 
immediate repair. Next, the bearings must be well oiled, so the oil will have a chance to get worked into the bearings.

If the knife is still in the binder, it should now be pulled and sharpened, if it is a plain one, or if a rough edge sickle broken sections should be knocked off and replaced by new ones.

The canvases should now be overhauled. Buckles, straps and slats should be replaced where they are broken or worn out. Patches should be sown on the holes, as here is where a great deal of trouble is often met with. Leaves and straws go through the holes and wrap around the rollers. This makes the roller too large, and thus jambs the canvas against the frame of the machine, causing the canvas to stop, sometimes tearing off slats or buckles. Before putting on the canvas, be sure that all rollers run free, and also that the frames are square. The canvas will not run true if they are not, but will run towards one corner. This, of course, will tear them.

In order to make the frame true, take a carpenter's square; hold the long end against the frame, the other against the roller. You will then see exactly how much they are out, and by screwing up the truss rods correct the fault.

The reel is one of the most important parts of the binder, yet few farmers seem to think so, judging by the way they have it tied up with binder twine, wire, etc. Unless there is a good reel on a binder, it will not make a good sheaf. The shape of a sheaf is determined by the way the grain is laid on the platform canvas. Unless the reel is perfectly true, it will not lay the grain so that 
a good sheaf can be made of it. In order to accomplish this, each slat of the reel must be parallel to the platform; that is both ends must be parallel to the platform. Also one end must not be ahead of the other.

We now have everything ready to start. The horses are hitched on and away we go to the field. Well, the sheaves are considered too small; we must make them larger. I think I have heard about a dozen different ways to accomplish this, and there are but three. The simplest way is to tighten up the screw on the trip. If this is not enough, lower the trip; and still another way is to slide the sheaf holder in towards the binder. This gives the grain less leverage on the trip, and thus makes a larger bundle. These methods apply to one of our own best known makes of binders.

Now that we have the sheaf adjusted to the required size, everything ought to go lovely. But troubles never come singly. The binder is missing sheaves. What now? Get a monkey wrench and tighten or loosen something on the knotter mechanism? No, certainly not; not until we find what the trouble is. First go to the twine box; ascertain if the twine is running freely. If all is well here, follow up the twine and see if the binder is threaded rightly. Next try the tension. If the tension is too tight, this will make the knotter miss, as it is liable to pull the twine out of the twine holder or disk. If not tight enough, the machine will also miss. If the twine is running right, the tension right, the binder 
threaded all right, then the trouble must be at the knotter. Now it is no use looking at the knotter because unless it is badly out of tune, it looks the same whether it is in perfect working order or not. Then what are we to do? We must look at the twine, when the binder misses, and ascertain what it is doing. If the twine is cut off square with the curl at the end, we may be certain that the disk or twine holder is not tight enough. By tightening this up very little at a time, we will eventually remedy the trouble. If, on the other hand, the twine is pulled off to a point, the disk is too tight and is cutting the twine. By slacking the disk, this can be corrected. To ascertain if there is anything wrong with the billbook, examine a sheaf that it tied. If the knot is pulled very tight and the ends of the twine frayed away, the billhook is too tight. If the knot is very slack and near the ends of the twine, the billhook is too slack. When oiling the machine, examine the needle to find if any foreign leaves or other matter has gathered in the eye; sometimes obstructions become wedged in so tightly that the twine will not run through, causing the knotter to miss sheaves.

Always run the binder as nearly level as possible. Never have it tilted back, as this will make it hard to pull; have it tilted forward enough to make it balance a little down in front. If it is thrown too much forward, it causes too much weight on the horses' necks, or, if there is a truck, too much weight on the little wheels, thus taking the driving power off the main wheel. 
If the binder suddenly sticks, never whip up the horses to start it. Get off and find the trouble. Probably a stick or root has got into the knife or a nut has dropped off somewhere and got between two cog wheels. When these things are cleared away, you may get on the machine and start away again.

Run the reel as high as possible without letting any grain fall forward, and always tie the sheaf as near the center as possible.

After the first half day a person should experience very ltttle trouble in running a binder. In fact, if a binder is well cared for each year, it will start off without any trouble.

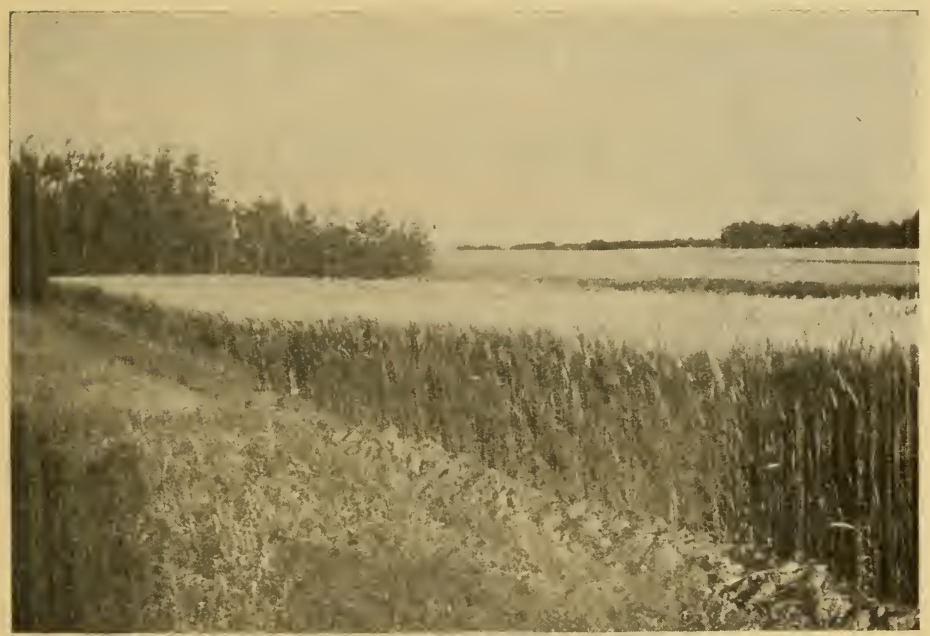

Fig. 39.-A field of Marquis wheat. 


\section{INDEX}

Acme harrow, 143

\section{A}

Alaska wheat, 21

Alberta Red wheat, 142, 143

Alfalfa as a fertilizer, 112

\section{B}

Backsetting, 148, 149, 151, 159

Binder, how to operate, 187

Bluestem wheat, 22

Breaking prairie sod, 148; deep breaking, 151

$\mathrm{C}$

California, methods of farming in, 123; old methods, 124

Campbell packer, 44

Campbell system, 181

Canada, culture methods in, 146; development of, 14; part of Great Plains, 134; rainfall in, 137; soil of, 135; wheat areas, 138; wheat production, 12

Capillarity, how to restore, 46

Cereals of America, 6; world's production, 9, 10

Chinch bug, 92,94

Climate, influence of, 32 ; wheat requirements, 38

Club Head wheat, 22, 23; on Pacific coast, 129

Combine, 73, 74; where used, 74; in California, 121

Community seed, 36

Cost of production, 88; in different countries, 89; on Pacific coast, 133

Cultivation, after seeding, 65, 184; shallow furrow, 57

Disk cultivator, 48

D

Durum wheat, 22, 23, 25; in Canada, 141

E

Egyptian wheat, 21

Elevators, co-operative, 87 ; independent, 85

Embryo, 19

Endosperm, 19

F

Fertilization, green manure, 117; manure, 115; summer fallowing, 117; use of straw, 114

Fertilizers needed by wheat, 108

Formaldehyde for stinking smut, 96 ; a poison, 97 
Ghirka wheat, 22

G

Grading of wheat, 85

Grain, color, 19; physical parts, 19; variation in size, 19

Grain weevil, 95

Green manuring, effect of, 119; at Fort Hays station, 117

$\mathrm{H}$

Harvest, 70; date of, 72; in Canada, 161; methods of, 73

Header, 72

Hessian fly, 59, 92, 94

Hopkins, opinion of, 112

Individual practices, 169

Inspection of wheat, 86 , local grains, 86

Kharkof wheat, 29, 142, 143

K

L

Legumes as fertilizers, 112; in rotation, 39

Listing, 17; advantages of method, 49; contour, 51; depth of, 49 ; for wheat, 47; effect on yield, 52

M

Macaroni wheat, 25, 26

Marketing of wheat, 81,82 ; prices, 84 ; tricks of, 84

Marquis wheat, 179

Mixed farming, system of, 107

$\mathrm{N}$

Nitrogen in soil, 110; in clover crop, 113; in roots of alfalfa, 112

\section{$\mathbf{P}$}

Pacific coast, wheat growing on, 122

Packing with subsurface packer, 56

Pasturing wheat, 67,68

Plant food, amount removed by wheat, 113; constituents of, 110 ; development of, 41 ; digestion of, 41 ; made available, 41

Plowing, 43; deep, 47; fall, 155; in California, 128; shallow, 54

Prize wheat 1911, 177; of 1913,178

R

Red Fife wheat, 22; early maturing, 40; origin of, 139

Rolling wheat, 67

Root system of wheat, 16,37

Rotation of crops to prevent drifting, 55; influence on wheat yields, 108; in Canada, 157; plans of, 102; for semi-arid land, 104

Rust of wheat, 95 
Saunders, work of, 143

\section{$\mathbf{S}$}

Scoring wheat, 90 ; score card, 91

Seed, adaptation of, 29; breeding, 32; cleaning and grading, 30 ; germination of, 16

Seed bed, firming of, 44; physical condition, 42; requirements, 40,175

Seeding, depth of, 62 ; early, 59 ; methods of, 60 ; thickness of, 61,184

Seeding machinery, 163; broadcast seeder, 163; drills, 164, 165; disk drill, 167; forms of drills, 166

Shocking, 75; kinds of shocks, 76

Shrinkage of grain, 82

Smut, damage from, 95 ; treatment of, 31,96 ; hot water treatment, 98 ; loose smut, 97

Soil drifting, how to prevent, 55,56 ; deep furrows, 58

Soil fertility, how maintained, 100; cause of loss, 101

Soil moisture, 45, 46; conservation of, 129, 153, 154

Soil mulch, 44

Soil required by wheat, 38

Spring mowing, 69

Spring wheat, 11 ; on fallow land, 50

Stacking, 77; how to begin, 78; how to complete, 79 ; not when damp, 81

Subsurface packer, 44; Dunham packer, 47

Summer fallow, 51; clean summer fallow, 152; cultivation of, 174 ; in regions of light rainfall, 152 ; methods of, 53

Summer tilling, 49, 54, 55; in Canada, 182; in California, 125 $T$

Threshing directly from the shock, 81 ; from the field, 83

Trap crops, 94

Turkey Red wheat, 22, 29, 30

W

Washington, culture methods in, 127

Weeds, 92

Wheat, countries, 11 ; chemical composition of, 28; flower and fruit, 16; hard wheat, 25; milling varieties, 23; Russian, 31 ; soft wheat, 24 ; stooling, 17 ; types of, 21 ; varieties, 20 .

Wheat-sick land, 102

Winter killing on drilled land, 60; causes of, 63, 64; to prevent, 65

Winter wheat, 11; followed by potatoes, 60 ; on Pacific coast, 131; preparation of land for, 158; quantity of seed, 160; time to sow, 160; varieties in Canada, 142

Yields of wheat, cause of low yields, 70

Zavitz, work of, 144

\section{Z}








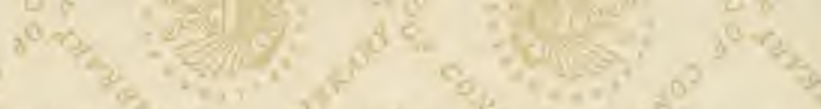

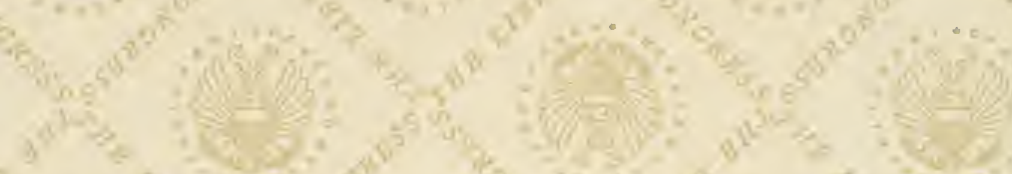

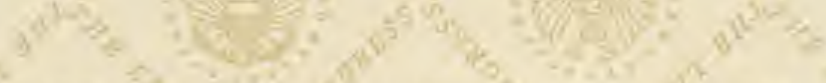

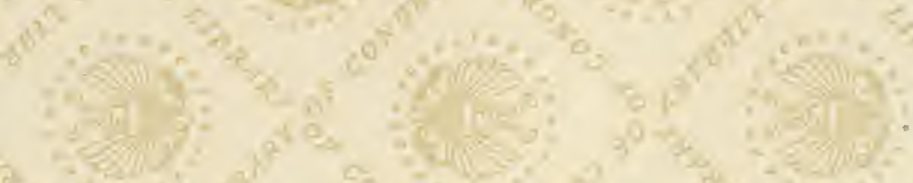

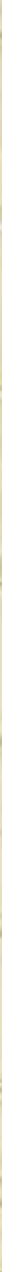

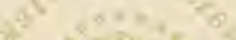


FEB 78 


\section{LIBRARY OF CONGRESS

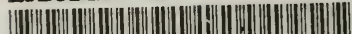

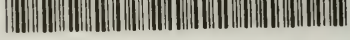 \\ 口002766 3114}

